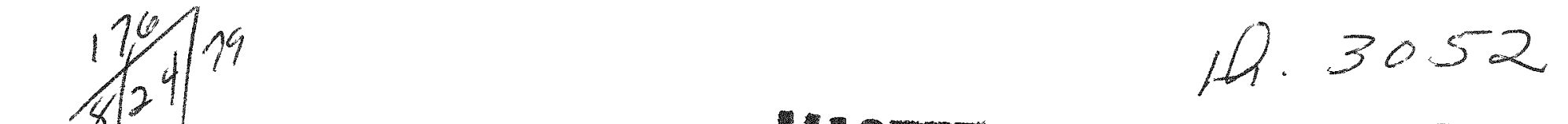

GA-A15343

UC-77

\title{
HTGR FUEL REPROCESSING PILOT PLANT: RESULTS OF THE SEQUENTIAL EQUIPMENT OPERATION
}

\author{
by \\ J. B. STRAND, D. E. FIELDS, C. A. KERGIS, \\ J. M. MCNAIR, and W. S. RICKMAN
}

Prepared under

Contract DE-AT03-76SF71053

for the San Francisco Operations Office

Department of Energy

DATE PUBLISHED: MAY 1979 


\section{NOTICE}

This report was prepared as an account of work sponsored by the United States Government. Neither the United States nor the United States Department of Energy, nor any of their employees, nor any of their contractors, subcontractors, or their employees, makes any warranty, express or implied, or assumes any legal liability or responsibility for the accuracy, completeness or usefulness of any information, apparatus, product or process disclosed, or represents that its use would not infringe privately owned rights.

Printed in the United States of America Available from

National Technical Information Service

U.S. Department of Commerce

5285 Port Royal Road

Springfield, VIrginia 22161

Price: Printed Copy $\$ 7.25$; Microfiche $\$ 3.00$ 


\section{DISCLAIMER}

This report was prepared as an account of work sponsored by an agency of the United States Government. Neither the United States Government nor any agency Thereof, nor any of their employees, makes any warranty, express or implied, or assumes any legal liability or responsibility for the accuracy, completeness, or usefulness of any information, apparatus, product, or process disclosed, or represents that its use would not infringe privately owned rights. Reference herein to any specific commercial product, process, or service by trade name, trademark, manufacturer, or otherwise does not necessarily constitute or imply its endorsement, recommendation, or favoring by the United States Government or any agency thereof. The views and opinions of authors expressed herein do not necessarily state or reflect those of the United States Government or any agency thereof. 


\section{DISCLAIMER}

Portions of this document may be illegible in electronic image products. Images are produced from the best available original document. 
GA-A15343

UC-77

\title{
HTGR FUEL REPROCESSING PILOT PLANT: RESULTS OF THE SEQUENTIAL EQUIPMENT OPERATION
}

\author{
by \\ J. B. STRAND, D. E. FIELDS, C. A. KERGIS, \\ J. M. McNAIR, and W. S. RICKMAN
}

Prepared under

Contract DE-AT03-76SF71053 for the San Francisco Operations Office Department of Energy

GENERAL ATOMIC PROJECT 3261

DATE PUBLISHED: MAY 1979

\section{GENERAL ATOMIC COMPANY}


ABSTRACT

The second sequential operation of the HTGR fuel reprocessing colddry head-end pilot plant equipment has been successfully completed. Twenty standard LHTGR fuel elements were crushed to a size suitable for combustion in a fluid bed burner. The graphite was combusted leaving a product of fissile and fertile fuel particles. These particles were separated in a pneumatic classifier. The fissile particles were fractured and reburned in a fluid bed to remove the inner carbon coatings. The remaining products are ready for dissolution and solvent extraction fuel recovery. 
SUMMARY

A pilot plant for the reprocessing of high-temperature gas-cooled reactor (HTGR) fuels is under development to demonstrate the processes and provide data for upgrading to a plant which is prototypical to a commercial plant.

This so-called cold-dry head-end pilot plant consists of the equipment required to process the HTGR fuel elements to a point where recovery of the fuel by dissolution and solvent extraction is practical. The plant has developed through individual testing and an initial sequential operation of the equipment, and a second sequential operation has recently been completed.

Twenty standard LHTGR fuel elements were successfully processed in the second sequential operation of the pilot plant equipment. The total weight of the elements processed was $2469 \mathrm{~kg}$, and they contained 279.8 $\mathrm{kg}$ of thorium and $18.2 \mathrm{~kg}$ of uranium.

The elements were crushed to a size suitable for burning in an integrated fuel element size-reduction system. Crushing was accomplished both on an individual element basis and on elements charged in rapid succession. Complete crushing of one element every 6 min was attained. The products were pneumatically transported to a product storage bunker and then to the crushed fuel element burner (primary burner) feed bunker. Overall fissile particle breakage was $8.7 \%$; overall fertile particle breakage was $1.5 \%$. Material accountability was excellent. No operating problems occurred throughout the crushing sequence. 
Graphite in the crushed fuel element product was combusted in the primary burner to reduce it to burned-back TRISO fissile and BISO thorium oxide fertile kernels. Combustion was interrupted after the product from the first ten elements had been charged so that an interim product removal could be effected. Fresh feed from the remaining elements was added to make up for the loss in volume, and the combustion operation was restarted and continued to completion. After cooling, the final product was pneumatically transported to a product bunker and the feed bunker of a pneumatic particle classifier in two batches. The carbon content had been reduced to 1.2 wt \% and $0.8 \mathrm{wt} \%$ in the initial and final products, respectively. No operating problems occurred in either the initial or final combustion operations.

Separation of the fissile and fertile fuel particles was accomplished in a zig-zag pneumatic classification system. Overall fuel particle breakage at this point was $3.2 \%$ of the fertile and $22.8 \%$ of the fissile particles. Separation of the fuel particles was improved over earlier results. Thorium and uranium recoveries were $98.9 \%$ and $93.3 \%$ in their respective process streams. Fault-free operation continued through the classification process.

A portion of the fissile product from classification was crushed in a double-roll particle crusher to expose the inner carbon coatings for combustion in a fluid-bed crushed particle burner (secondary burner). With only $0.3 \mathrm{~kg}$ remaining to be crushed, the crushing was stopped due to an overload on the drive motor which resulted in a tripped circuit breaker. Improper preload on the roll bearings caused the overload and resulted in a widening of the crusher gap and some unbroken particles.

The crushed fissile product was combusted in the secondary burner without operating problems. The final product contained only $0.3 \%$ burnable carbon. However, due to the widening of the crusher gap, over $8 \%$ of the fissile fuel particles remained unbroken after secondary burning. 
The overall thorium and uranium material balances were excellent through secondary burning, with $1.2 \%$ and $2.1 \%$ material unaccounted for, respectively.

Notable improvement in operations and results were obtained over an earlier sequential operation. In general, equipment operation, product specifications, and throughputs met or exceeded criteria. The minor problem areas should be easily overcome.

Further work will be required to upgrade the pilot plant to be fully prototypical to a remote hot-cell commercial facility. 
-

- 
CONTENTS

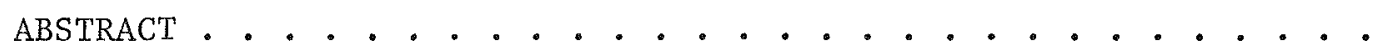

iii

SUMMARY

1. INTRODUCTION . . . . . . . . . . . . . . . . 1-1

References .................. 1-4

2. PROCESS DESCRIPTION . . . . . . . . . . . . . . . 2-1

3. EQUIPMENT DESCRIPTION . . . . . . . . . . . . . . 3-1

3.1. Fuel Element Size-Reduction System - UNIFRAME . . . 3-1

3.1.1. General Description . . . . . . . . . 3-1

3.1.2. Primary Crusher........... . . 3-2

3.1.3. Secondary Crusher ........... . 3-2

3.1.4. Tertiary Crusher ........... . 3-2

3.1.5. Screener Separator .......... . . 3-2

3.1.6. Oversize Crusher ........... 3-7

3.1.7. Ventilation Enclosure.......... . 3-7

3.1.8. Structural Machine Frame . . . . . . 3-7

3.1.9. Drive System . . . . . . . . . . . 3-8

3.2. Crushed Fuel Element Fluid-Bed Burner - Primary Burner 3-8

3.2.1. General Description . . . . . . . . 3-8

3.2.2. Fresh Feed System . . . . . . . . 3-8

3.2.3. Fluid-Bed Vessel .......... 3-11

3.2.4. Heating System ............ 3-11

3.2.5. Cooling System ........... 3-11

3.2.6. Gas Distributor ........... 3-11

3.2.7. Fines Recycle System ......... 3-11

3.2.8. Product Removal System ........ . 3-12

3.3. Air Classifier . . . . . . . . . . . 3-12

3.3.1. General Description . . . . . . . 3-12

3.3.2. Feed System.............. . 3-12

3.3.3. Zigzag Column............ 3-15 
3.3.4. Off-Gas Filtration System . . . . . . 3-15

3.3.5. Product Bunkers .......... . 3-15

3.4. Fuel Particle Crusher .............. 3-15

3.4.1. General Description ......... 3-15

3.4.2. Crushing System . . . . . . . . 3-16

3.5. Crushed Fuel Particle Fluid-Bed Burner - Secondary

Burner ............... . . 3-16

3.5.1. General Description .......... 3-16

3.5.2. Feed System ............ . . 3-23

3.5.3. Fluid-Bed Vessel and Integral Filters . . 3-23

3.5.4. Heating System .......... . 3-23

3.5.5. Cooling System . . . . . . . . . 3-23

3.5.6. Gas Distributor ......... . . 3-24

3.5.7. Product Removal System ........ . 3-24

3.6. Solids Handling Systems . . . . . . . . . . 3-24

3.6.1. General Description ......... . 3-24

References . . . . . . . . . . . . . . 3-25

4. INITIAL SEQUENTIAL OPERATION . . . . . . . . . . . 4-1

4.1. Background .............. . . . 4-1

4.2. Fuel Element Size Reduction........... 4-2

4.3. Crushed Fuel Element Burning .......... 4-3

4.4. Particle Classification ........... 4-5

4.5. Particle Crushing . . . . . . . . . . 4-6

4.6. Crushed Fuel Particle Burning. . . . . . . . 4 4-6

4.7. Overall Material Balance .. . . . . . . . 4-6

4.8. Overall Particle Breakage . . . . . . . . 4-7

References ................... . . . 4-7

5. SECOND SEQUENTIAL OPERATION .............. . . . 5-1

5.1. Feed Material .............. 5-1

5.2. Fue1 Element Size Reduction ........... 5-1

5.2.1. Equipment Changes ......... . 5-1

5.2.2. Crushing........... . . 5-1

5.2.3. Sampling and Results......... 5-3

5.3. Crushed Fuel Element Burning . . . . . . . . 5-6

5.3.1. Equipment Changes ......... 5-6

5.3.2. Burning Operations ........ . . 5-6 
5.3.3. Instrumentation . . . . . . . . 5-10

5.3.4. Product ............. 5- 10

5.4. Particle Classification ........... 5-25

5.4.1. Air Classification Operations ..... . 5-25

5.4.2. Feed Rates............ . . 5-25

5.4.3. Material Balances ......... 5-27

5.4.4. Sampling........... . . 5-30

5.4.5. Size Distribution . . . . . . . 5-32

5.4.6. Carbon Content .......... . 5-32

5.4.7. Particle Breakage ......... . 5-35

5.4.8. Heavy Metal Distribution ........ 5-35

5.5. Particle Crushing.............. 5-38

5.5.1. Equipment Changes . . . . . . . 5-38

5.5.2. Feed Material ......... . 5-39

5.5.3. Crushing Operations ......... . 5-39

5.6. Crushed Particle Burning .. . . . . . . . 5-42

5.6.1. Feed Material .......... . 5-42

5.6.2. Burning Operations ........ . 5-42

5.6.3. Product ............ . 5-47

6. ANALYTICAL TECHNIQUES . . . . . . . . . . . . 6-1

7. OVERALl MATERIAL BALANCE ................ . . . 7-1

8. FUEL PARTICLE BREAKAGE SUMMARY . . . . . . . . . . . 8-1 Reference ................... . . . 8-1

9. COMPARISON OF INITIAL AND SECOND SEQUENTIAL OPERATIONS . . . 9-1

10. CONCLUSTONS . . . . . . . . . . . . . . 10-1

11. FUTURE WORK . . . . . . . . . . . . . 11-1

11.1. Genera1 ............... 1. . 11-1

11.2. Fuel Element Size-Reduction System . . . . . . . 11-1

11.3. Crushed Fuel Element Burner . . . . . . . . 11-5

11.4. Fuel Particle Classification . . . . . . . . 11-7

11.5. Fuel Particle Crusher . . . . . . . . . . 11-8

11.6. Crushed Fuel Particle Burner ... . . . . . 11-8

11.7. Solids Handling Systems . . . . . . . . . . 11-9

11.8. Conclusions ............... . . 11-9

References .................. 1 11-10

ACKNOWLEDGMENTS . . . . . . . . . . . . . . . . . 12-1 
1-1. LHTGR fuel particles . . . . . . . . . . . . 1-2

1-2. LHTGR fuel element . . . . . . . . . . . . . 1-3

1-3. Cold dry head-end pilot plant arrangement . . . . . 1-5

2-1. Cold dry head-end pilot plant layout . . . . . . . . 2-2

3-1. Uniframe mechanical subsystem . . . . . . . . . . . 3-3

3-2. Fuel element size-reduction equipment assembly . . . . . 3-5

3-3. Primary burner system . . . . . . . . . . . 3-9

3-4. The $0.40-\mathrm{m}$ primary burner assembly ......... 3-10

3-5. Fuel particle classification system . . . . . . . . 3-13

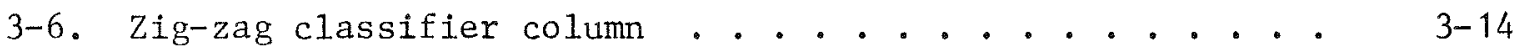

3-7. Fuel particle crusher and drive motor ........ . 3-17

3-8. Fuel particle crusher ............. . 3-18

3-9. Secondary burner system . . . . . . . . . . . 3-19

3-10. Cross section of $0.20-\mathrm{m}$ secondary burner system . . . . 3-21

3-11. Typical transport system . . . . . . . . . . 3-26

4-1. Primary burner with pneumatic fines recycle system . . . 4-4

5-1. Composite size distribution of crusher product from sequential operation ............. 5-7

5-2. Primary burner bed differential pressure . . . . . . 5-11

5-3. Primary burner filter pressure . . . . . . . . . 5-12

5-4. Primary burner mid-bed temperature . . . . . . . . 5-13

5-5. Primary burner fresh feed rotary valve rpm . . . . . 5-14

5-6. Primary burner Co off-gas concentration ..... . . 5-15

5-7. Primary burner above-bed temperature and $\mathrm{O}_{2}$ off-gas

5-8. Primary burner cyclone pressure .......... . 5-17

5-9. Primary burner lower cooling air flow . . . . . . . 5-18

5-10. Primary burner upper cooling air . . . . . . . . . 5-19

5-11. Primary burner fines pipe cooling air . . . . . . . . 5-20

5-12. Primary burner cyclone cooling air . . . . . . . . 5-21

5-13. Primary burner plenum gas flows . . . . . . . . . 5-22

5-14. Primary burner midreactor gas flows . . . . . . . 5-23

5-15. Secondary burner mid-bed temperature... . . . . . . 5-43 
5-16. Secondary burner pressure . . . . . . . . . 5-44

5-17. Secondary burner gas flows .......... 5-45

5-18. Secondary burner off-gas concentration . . . . . . . 5-46

7-1. Thorium and uranium material balance for cold pilot plant sequential operation ................ 7-2

TABLES

5-1. LHTGR standard fuel elements used in second sequential operation ............... . . 5-2

5-2. Fuel element crushing data. . . . . . . . . . 5-4

5-3. Particle breakage in Uniframe transport to crusher product burner ................ 5-5

5-4. Crusher product bunker weights recorded during sequential operation ............... 5-8

5-5. Primary burner products for pilot plant sequential operation ................. . . 5-24

5-6. Primary burner product bunkex and classifier feed bunker weights recorded during sequential operation . . . . . 5-26

5-7. Classifier feed rates from the pilot plant sequential operations . . . . . . . . . . . . . . . . . . . . 5-28

5-8. Air classification material balance . . . . . . . 5-29

5-9. Classifier product bunker and actual product weights recorded during sequential operation . . . . . . . . 5-31

5-10. Size distributions of classified products from the pilot plant sequential operations ........... 5-33

5-11. Carbon content of classified products from the pilot plant sequential operations .................

5-12. Broken fuel particle content of classified products from the pilot plant sequential operations ...... . 5-36

5-13. Heavy metal content and distribution in the classified products from the pilot plant sequential operations . . 5-37

5-14. Fuel particle crusher feed characteristics from sequential operation .............. . . . 5-40

5-15. Sequential operation particle crusher product used for secondary burner feed ............. 5-41

5-16. Secondary burner sequential operations product characteristics 


\section{TABLES (Continued)}

8-1. Fuel particle breakage for pilot plant sequential operations . . . . . . . . . . . . . . . 8-2

8-2. Broken fuel particles in classified products . . . . . . 8-3 


\section{INTRODUCTION}

General Atomic Company (GA) has the responsibility for development of a pilot plant for reprocessing HTGR fuels. The pilot plant will utilize unirradiated fuels to demonstrate the processes and to provide sound technical data for upgrading to a cold plant which is prototypical to a commercial plant for reprocessing irradiated fuels.

The fuel in an HTGR of the 2000- to 3000-MW(t) size consists of TRISO coated highly enriched uranium oxycarbide fissile particles and BISO coated thorium oxide fertile particles (Fig. 1-1). These particles are contained in fuel elements made from graphite, which is a neutron moderator (Fig. 1-2).

Separation of the fissile from the fertile fuel particles is necessary to recover the bred-in fissionable U-233 from the fertile particles and to recover the remaining fissionable U-235 from the fissile particles or to allow disposal of the fissile particles to remove the bred-in U-236, a neutron poison. Crossover from one particle recovery stream to the other is undesirable because of cost penalties associated with U-236 poisoning of the fertile particles and disposal of U-233 with the fissile particles. Therefore, the development of an economic commercially viable process for the recovery of bred-in U-233 and the remaining usable U-235 from spent fuel is an important step in making the HTGR a source of nuclear energy for generation of electric power (Ref. 1-1).

The so-called dry head-end processes of the cold pilot plant consist of crushing the fuel elements to a size suitable for the subsequent removal of the element graphite by combustion in a fluid-bed burner, pneumatic separation of the fissile and fertile fuel particles, crushing 


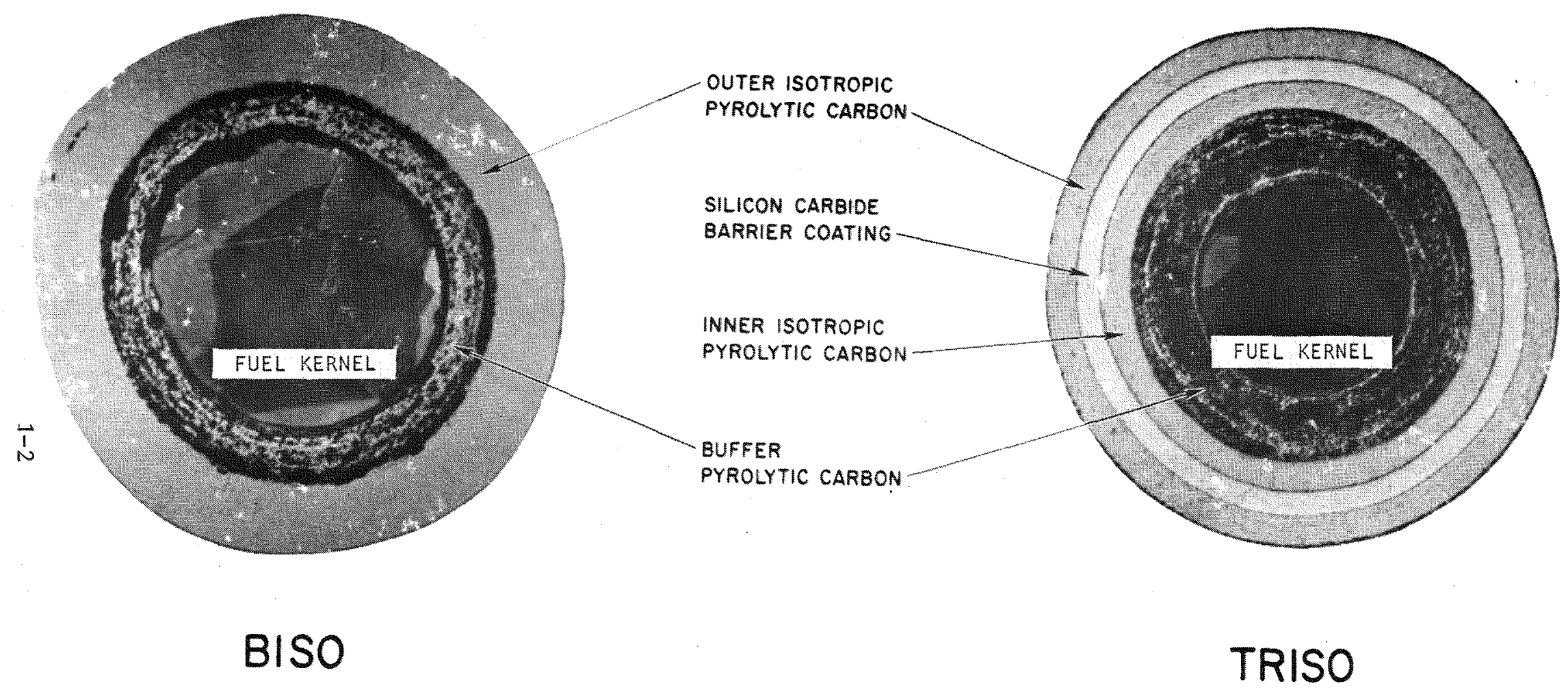

Fig. 1-1. LHTGR fuel particles 

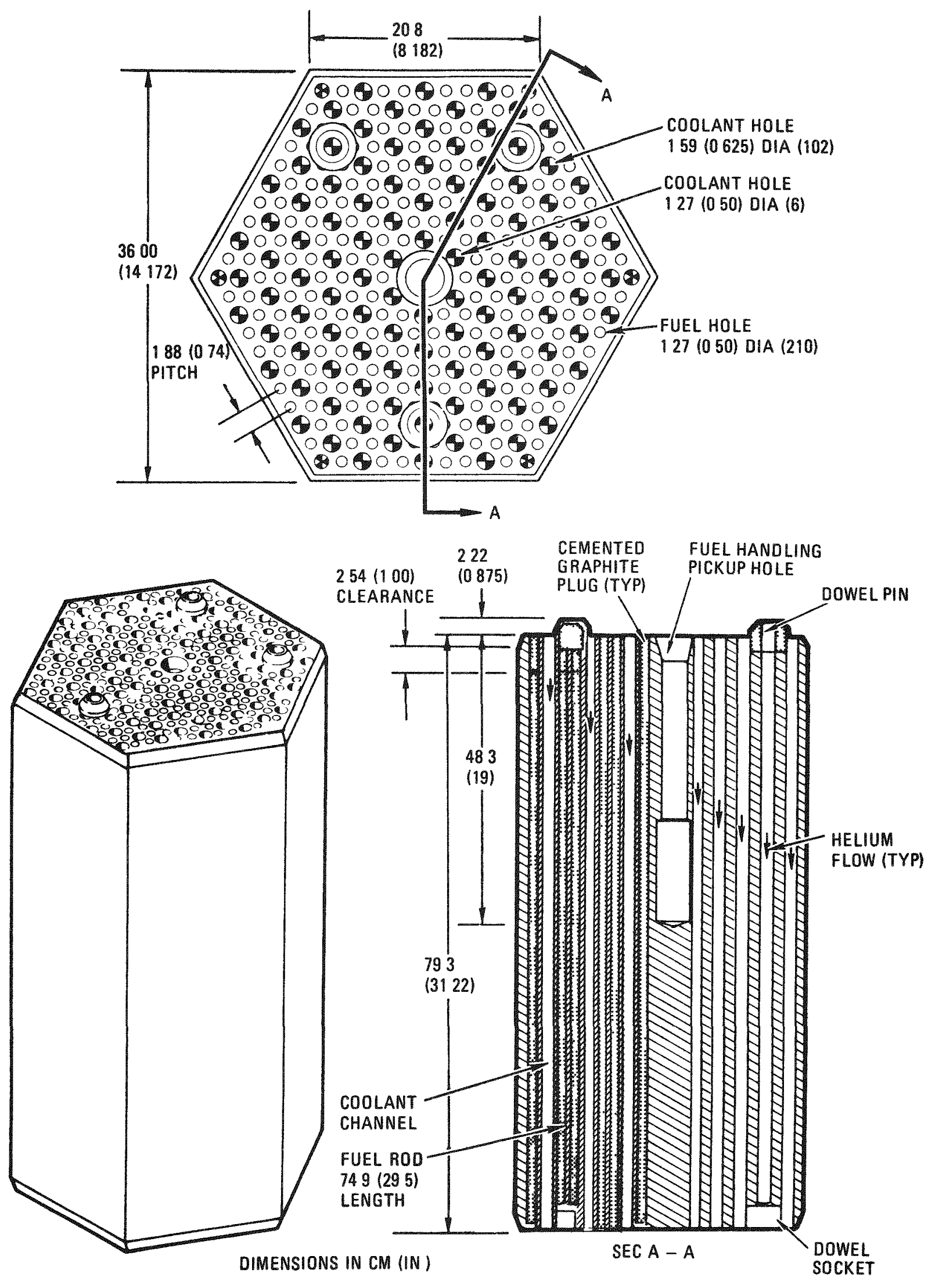

F1g. 1-2. LHTGR fuel element 
the TRISO coated particles to expose the inner carbon coatings, and removal of these coatings by combustion in a fluid-bed particle burner. These processes are followed by the so-called wet head-end processes, which consist of dissolution and separation of the nuclear from the insoluble materials and separation of the uranium, thorium, and fission products by solvent extraction.

In June 1976, GA completed construction of the cold-dry head-end pilot plant (Fig, 1-3). Since its completion, each system has been used for experiments to verify designs and in two separate sequential operations of the entire pilot plant.

The results of the design verification (or qualification testing) are summarized in Ref. 1-2. A summary of the initial sequential operation of the pilot plant is given in Ref. 1-3. This report summarizes the results of the second sequential operation of the entire dry head-end pilot plant as a system.

\section{REFERENCES}

1-1. Brooks, L. H., C. A. Heath, and J. J. Shefcik, "HTGR Fuel Reprocessing Technology," in Proceedings of the A.I.Ch.E. Symposium on Gas-Cooled Reactor Fuel Cycles, August 29 - September 1, 1976, Atlantic City, N. J. (GA-A12807, April 30, 1976).

1-2. "The General Atomic Reprocessing Pilot Plant Description and Results of Initial Testing," DOE Report GA-A14642, General Atomic Company, December 1977.

1-3. "The General Atomic HTGR Fuel Reprocessing Pilot Plant: Results of Initial Sequential Equipment Operation," DOE Report GA-A15081, General Atomic Company, September 1978. 


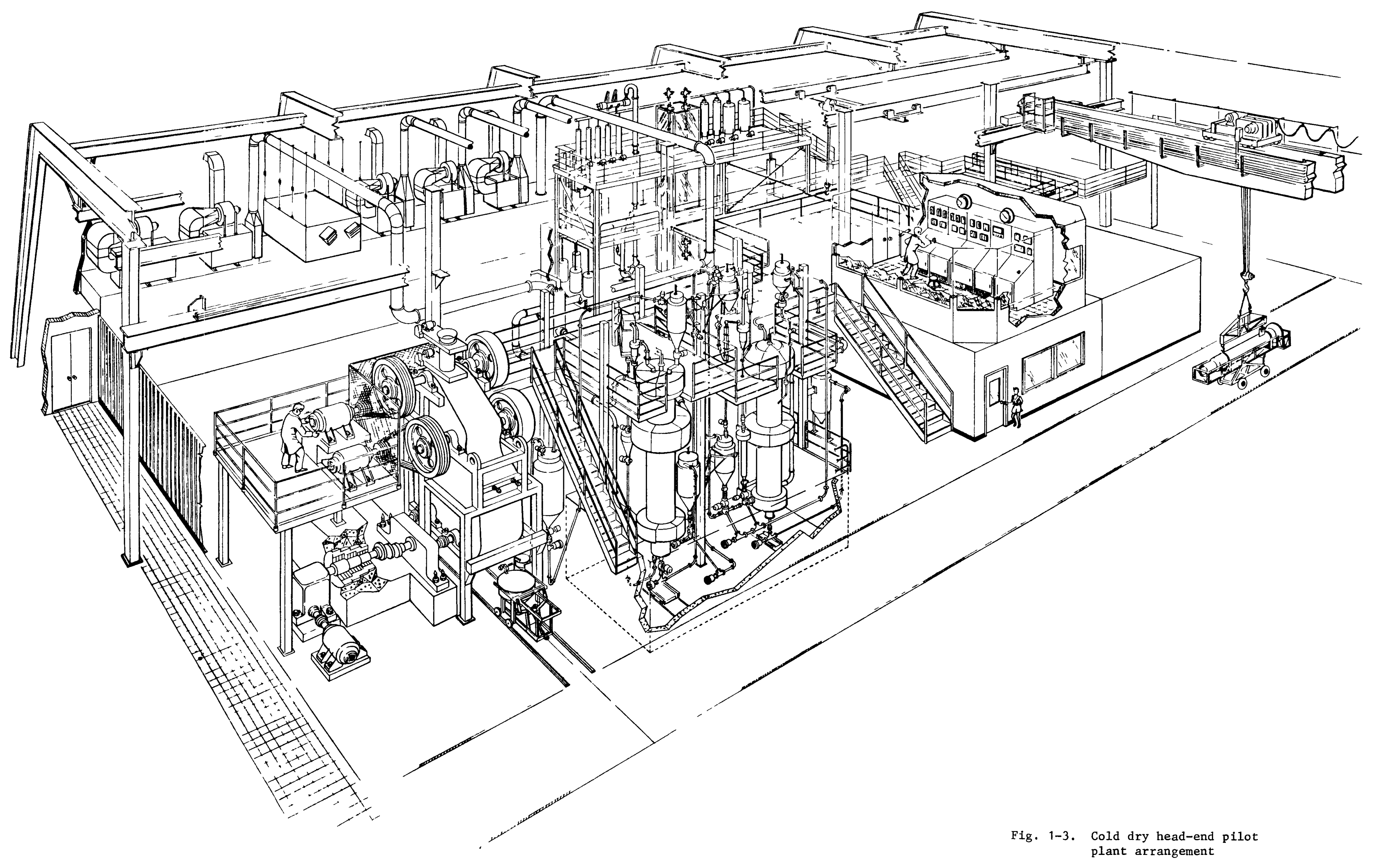




\section{PROCESS DESCRIPTION}

The overall purpose of the dry head-end systems in HTGR fuel reprocessing is to prepare the fuel particles for dissolution and subsequent recovery of the fissionable materials by solvent extraction. The flow sheet is comprised of fuel element size reduction, crushed fuel element burning, particle classification, particle crushing, and crushed particle burning. These unit operations are connected by solids hand1ing systems (Fig. 2-1).

The fuel elements are reduced to $<4750-\mu \mathrm{m}$ fragments by a series of two overhead eccentric jaw crushers and a double-roll crusher. The crushed product is screened to remove the $+4750-\mu \mathrm{m}$ fragments. These are further crushed in a single-roll crusher. The major equipment of the crushing system is mounted in a specially designed framework that replaces the standard machine frames of the overhead eccentric jaw crushers and the double-roll crusher by an array which utilizes gravity flow, eliminates the need for intracrusher material transport devices, and minimizes material holdup. This system has been designated Uniframe because of the integration of all the equipment into the specially designed single structure.

The crushed material is pneumatically conveyed to a product bunker for storage and then to the feed bunker of the fluid-bed (primary) burner on an as-needed basis.

The crushed fuel is fluidized with carbon dioxide in the primary burner, the bed temperature is increased to $700^{\circ} \mathrm{C}$ by electric induction heating, then oxygen is introduced to begin combustion. The fluidized bed is maintained at $2900^{\circ} \mathrm{C}$ by air cooling. Fine particles that are 


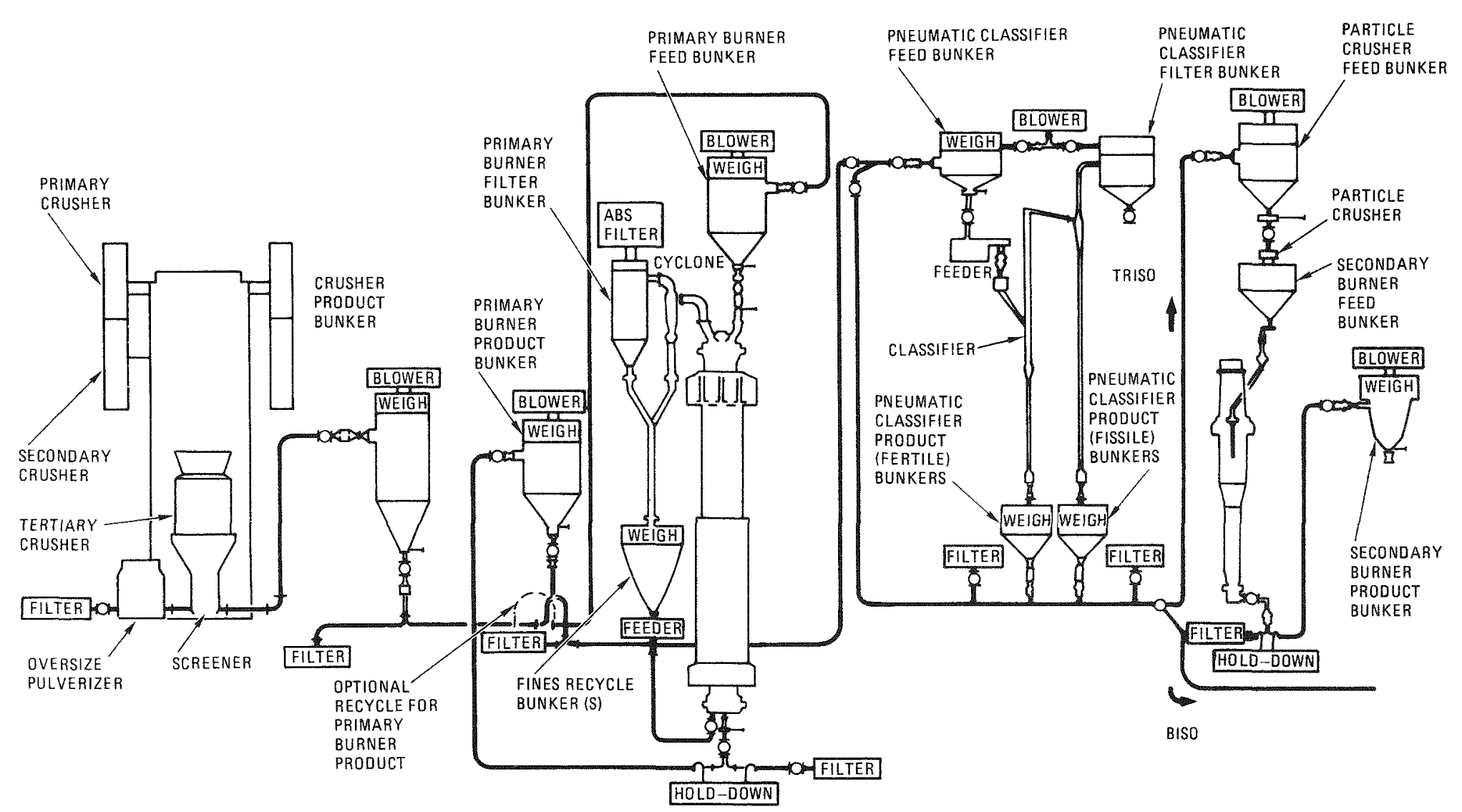

Fig. 2-1. Cold dry head-end pilot plant layout 
entrained by the fluidizing gas are recycled to the bed after separation from the gas. Fresh feed is added to the burner continuously. As the graphite and outer carbon coatings on the particles are burned off, the product is semicontinuously pneumatically conveyed to a product bunker for storage and then to the feed bunker of the air classifier.

The burned-back fuel particles are fed into a moving air stream within a zig-zag classification column. The lighter TRISO fissile particles, which are entrained in the upward flowing gas, are separated from the gas by a cyclone and filter and fall into a receiving bunker. The dense BISO particles fall through the gas stream into a separate receiving bunker. These particles, which are burned back to the fuel, are ready for dissolution.

The burned-back TRISO coated particles have inner carbon coatings which must be burned off to avoid interference in the solvent extraction process. These particles are batch-wise pneumatically conveyed to the particle crusher feed bunker and then fed to the double-roll crusher, where the outer silicon carbide coatings are fractured to expose the inner carbon coatings and fuel.

The crushed particles are gravity fed into the fuel-particle fluidized-bed (secondary) burner feed hopper. The entire batch is fed to the secondary burner and fluidized with carbon dioxide. The fluidized bed of crushed particles is heated by an induction heater to ignition temperature. Oxygen is then introduced to begin combustion. The bed is maintained at $2900^{\circ} \mathrm{C}$ by a combination of induction heating and air cooling. Fine particles that are entrained by the fluidizing gas are separated from the gas by in-vessel filters and returned to the bed by blowing back the filters. After combustion is complete, the product is pneumatically conveyed to the secondary burner product bunker, ready for dissolution. 


\section{EQUIPMENT DESCRIPTION}

\subsection{FUEL ELEMENT SIZE-REDUCTION SYSTEM - UNIFRAME}

\subsubsection{General Description}

Fuel element size-reduction is accomplished in a three-stage crushing system which consists of two overhead eccentric jaw crushers and a double-roll crusher. The crushers are followed by a screener separator and a single-roll oversize product crusher. The major equipment is mounted in a single framework which replaces the standard machine frames to utilize gravity flow, minimize material holdup, and eliminate the need for intracrusher material transport devices. The system has been designated Uniframe because of the integration of equipment into the single structure.

The major components of the Uniframe are:

1. Primary crusher.

2. Secondary crusher.

3. Tertiary crusher.

4. Screener separator.

5. Oversize crusher.

6. Ventilation enclosure.

7. Structural machine frame.

8. Drive system.

A brief description of these components follows. A more detailed description is given in Ref. 3-1. A detailed description of the system development prior to the initial pilot plant sequential operation appears in Ref. 3-2. An evaluation of the design after development testing is 
presented in Ref. 3-3. The arrangement of the major components without the drive systems and ventilation enclosure is shown in Fig. 3-1; the entire system is illustrated in Fig. 3-2.

\subsubsection{Primary Crusher}

The primary crusher is an overhead eccentric jaw crusher that has been redesigned for compatibility with radioactive fuel element crushing and remote operation. It consists of two major assemblies: the pitman and the stationary jaw. The fuel elements are crushed to $<0.15-\mathrm{m}$ ringsize fragments between wear plates on the pitman and stationary jaw. Crushing is induced by the motion of a rotating eccentric shaft and toggles on the pitman.

\subsubsection{Secondary Crusher}

The secondary crusher is also an overhead eccentric jaw crusher that has been redesigned for compatibility with radioactive fuel element crushing and remote operation. The primary crusher product gravity discharges into the secondary crushing cavity and is further reduced to $<0.5-\mathrm{m}$ fragments. The operation and principle of the secondary crusher are similar to those of the primary crusher.

\subsubsection{Tertiary Crusher}

The tertiary crusher is a double-roll crusher that has been redesigned for compatibility with radioactive fuel element crushing and remote operation. The secondary crusher product gravity discharges into the tertiary crusher and is reduced to $\leq 4750-\mu \mathrm{m}$ ring-size fragments by crushing between the surfaces of the two counter-rotating rolls.

\subsubsection{Screener Separator}

The screener separator consists of two major assemblies: a stationary outer housing and an inner vibrating section. The outer housing acts as 

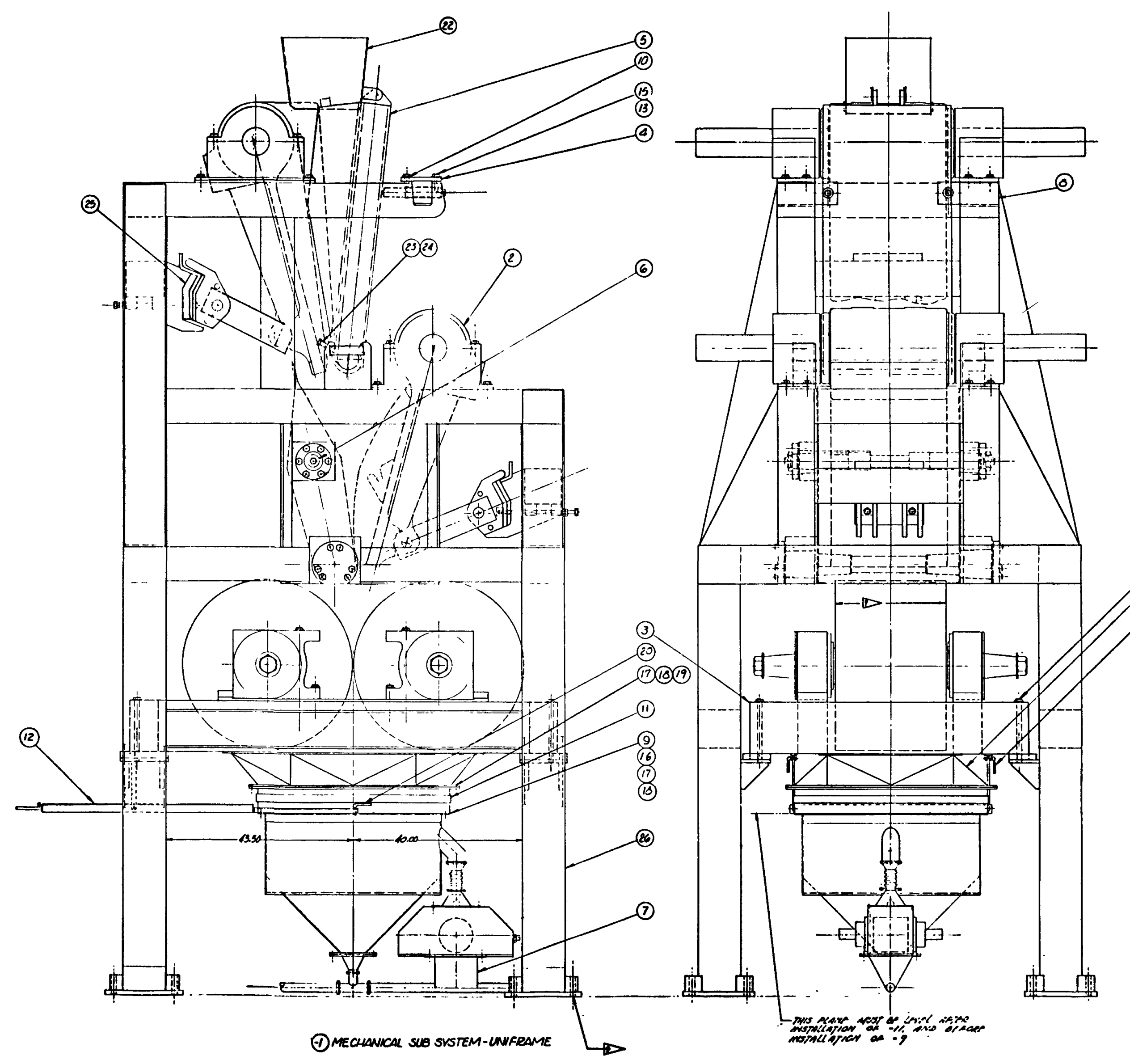

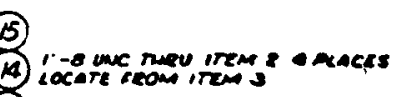

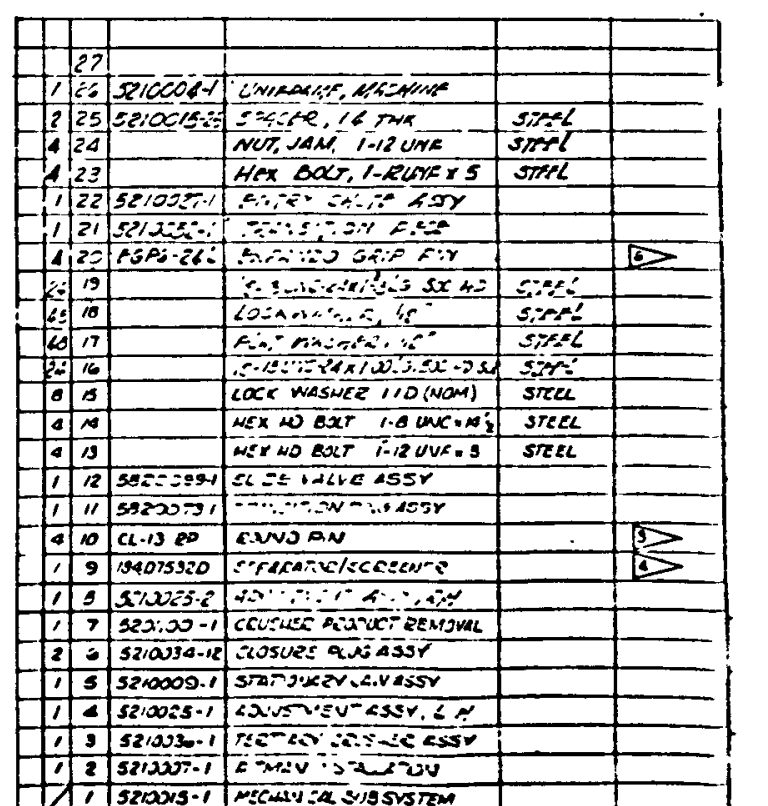

Fig. 3-1. Uniframe mechanical subsystem 


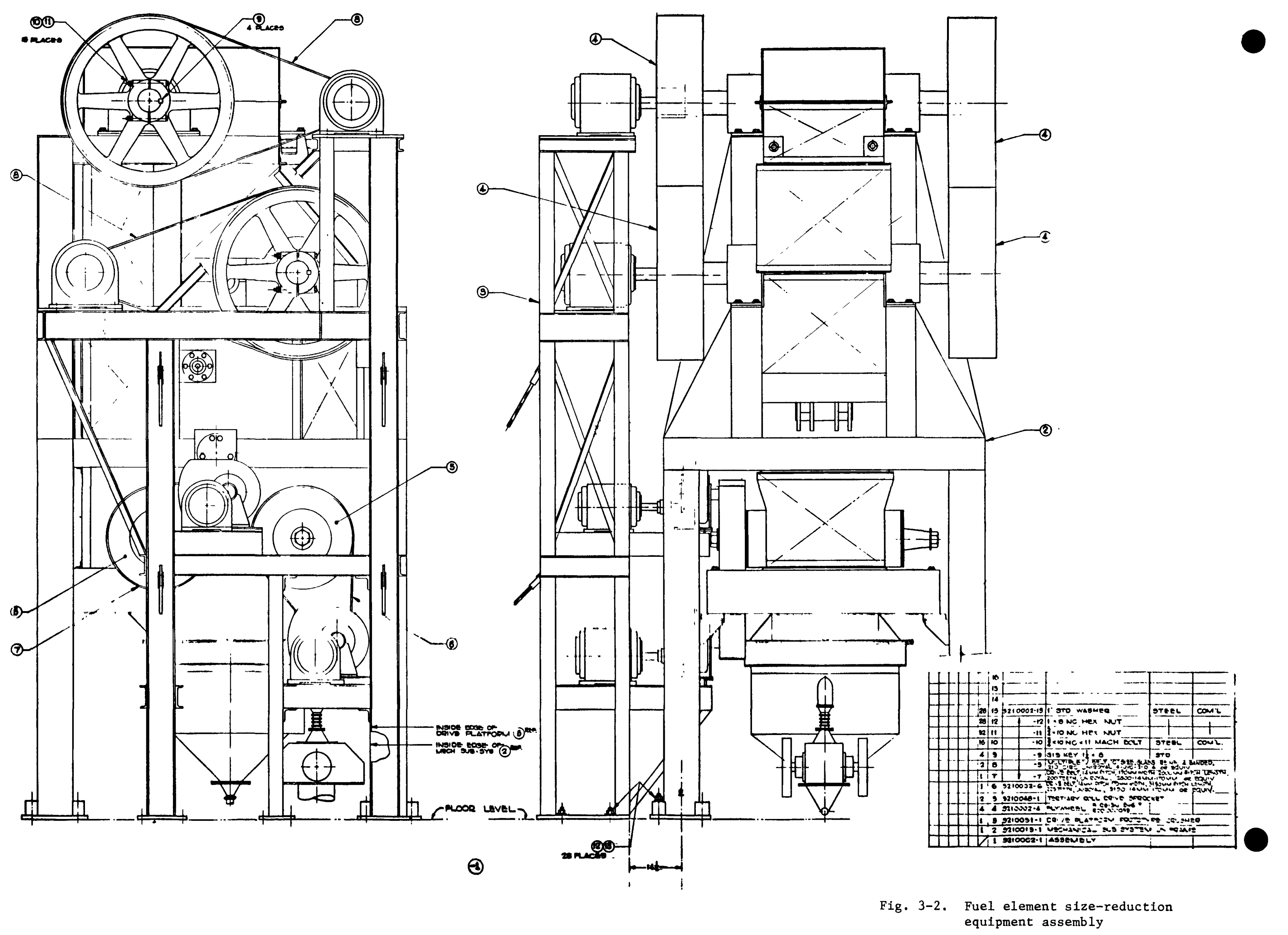


part of the ventilation enclosure, as a feed hopper for the pneumatic transport system, and as support for the inner vibrating section. The vibrating section has a centrally located motion generator suspended beneath a 4750- $\mu \mathrm{m}$ wire screen. Tertiary crusher product gravity discharges onto the vibrating screen. The $\leq 4750-\mu \mathrm{m}$ ring-size material passes through the screen and into the outer housing for transport to the product bunker. Material greater than $4750 \mu \mathrm{m}$ is directed to the oversize crusher.

\subsubsection{Oversize Crusher}

The oversize crusher consists of a single eccentrically mounted roll, which rotates and oscillates between two fixed wear plates. This motion produces a parallel alternating pinch action between the roll and the two plates. The crusher accepts the oversize material gravity discharged from the screener, reduces it to $<4750-\mu \mathrm{m}$ ring size, and gravity discharges it into the pneumatic transport system.

\subsubsection{Ventilation Enclosure}

The ventilation enclosure is designed to (1) contain the dusts produced by the crushing operation, (2) minimize the surfaces of the Uniframe that are exposed to dust, (3) minimize losses due to material holdup, (4) provide a negative containment system to reduce the spread of radioactive materials outside the Uniframe, and (5) provide a common collection point for dust and crushed product for ease in transport.

\subsubsection{Structural Machine Frame}

The Uniframe machine frame is a structural weldment designed to replace all three of the crusher's standard machine frames. The single structure enables vertical stacking of components, conserves hot-cell space, and uses gravity for transport of materials between process stages. 


\subsubsection{Drive System}

The drive system is composed of the necessary drives for powering the three main size-reduction stages, the screener, and the oversize crusher. The primary, secondary, and tertiary crusher drives are mounted on a common structure that is separate from the Uniframe. The drives for the screener and oversize crusher are integral to these units.

\subsection{CRUSHED FUEL ELEMENT FLUID-BED BURNER - PRIMARY BURNER}

\subsubsection{General Description}

Crushed fuel element combustion is accomplished in a fluid-bed burner system that consists of a fresh feed system, fluid-bed vessel, heating and cooling systems, gas distributor, fines recycle system, and product removal system.

A brief description of these components follows. A more detailed description is given in Ref. 3-4. A detailed description of the system development prior to the initial pilot plant sequential operation appears in Ref. 3-5, and an evaluation of the design is given in Ref. 3-6. The entire system is illustrated in Fig. 3-3; the burner assembly is shown in more detail in Fig. 3-4.

\subsubsection{Fresh Feed System}

The fresh feed system consists of a bunker, knifegate valve, and rotary valve, all of which are located above the fluid-bed vessel to allow gravity feeding. The bunker serves for storage of crushed fuel element material after pneumatic transport from the large Uniframe product bunker. The knifegate valve provides a positive air-lock between the bunker and the fluid-bed vessel. The $0.10 \mathrm{~m}$ rotary valve is used to meter in the initial bed material and fresh feed during combustion. 

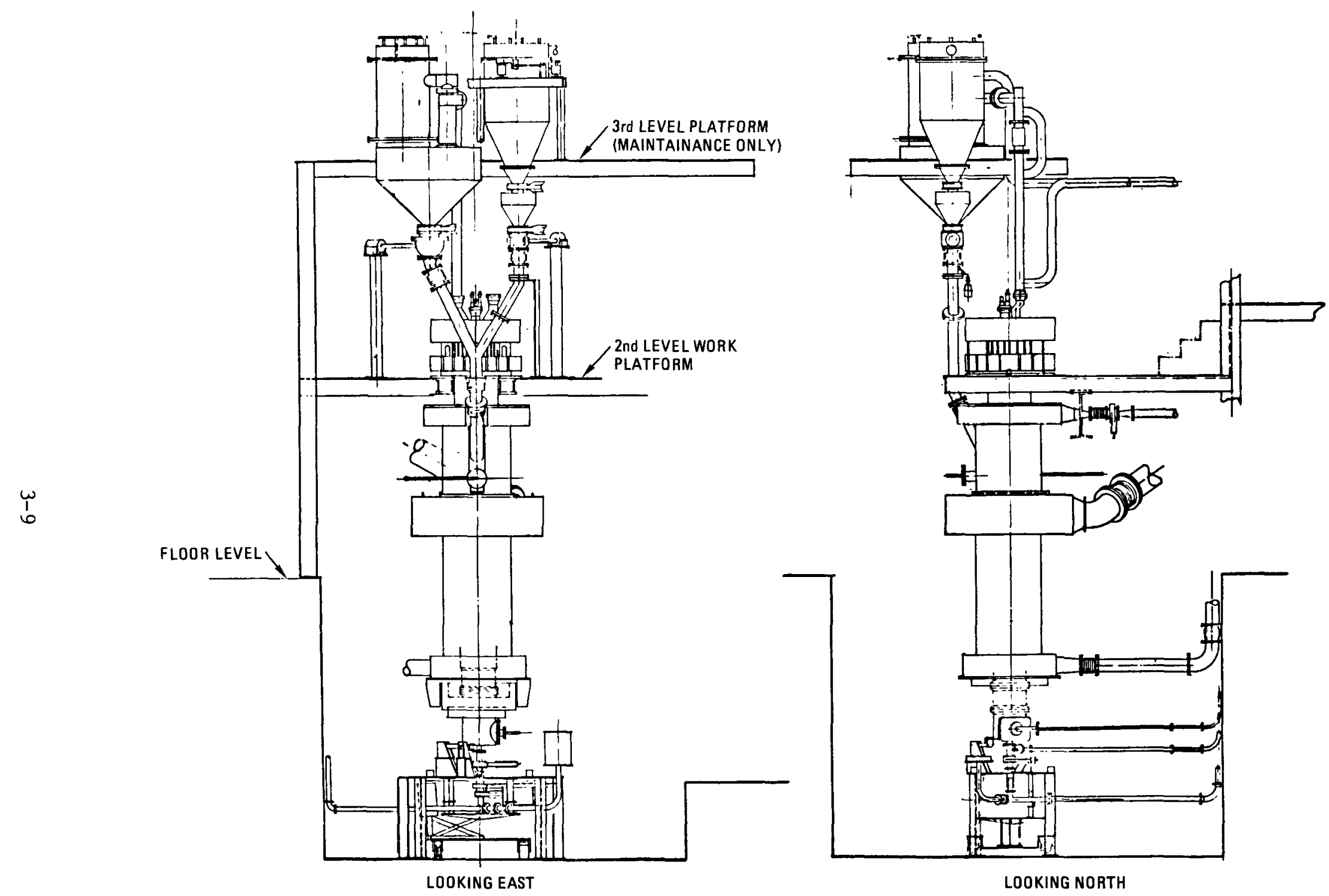

Fig. 3-3. Primary burner system 


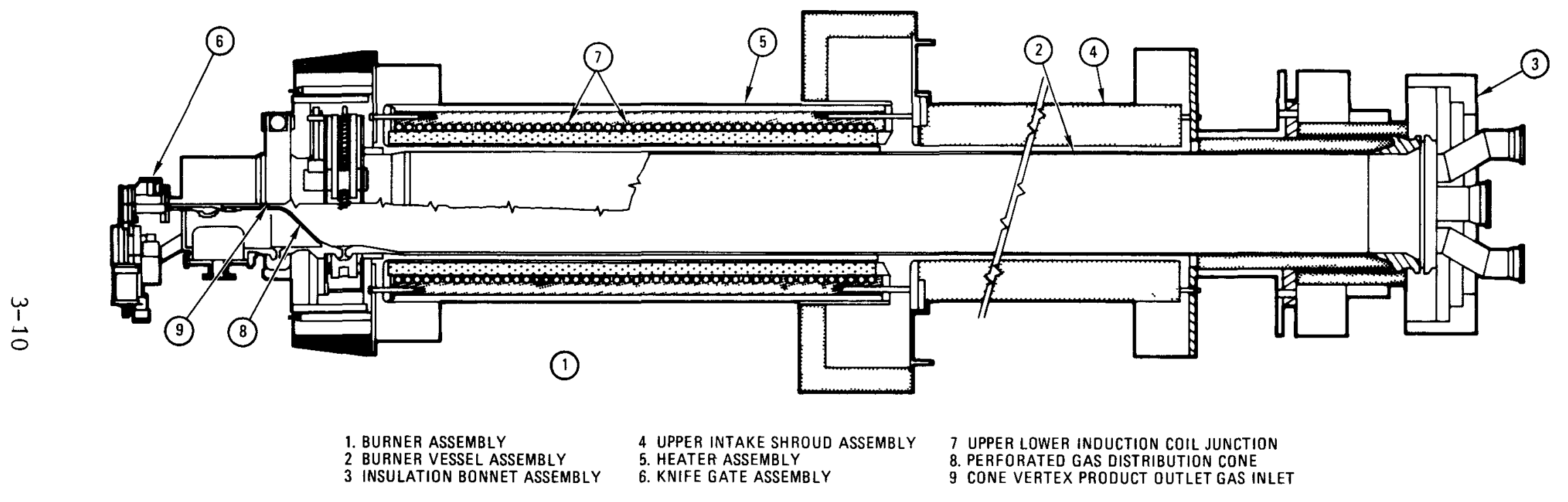

Fog. 3-4. The 0.40-m primary burner assembly 


\subsubsection{F1uid-Bed Vesse1}

The fluid-bed vessel is a 5-m-long Hastelloy $\mathrm{X}$ cylinder with a $0.40-m$ internal diameter. Pin fins are welded to the outside wall in a 2-m-long array to enhance heat transfer between the wall and the cooling air that flows through an annular space along the length of the vessel.

\subsubsection{Heating System}

The fluid-bed vessel is heated by induction with a motor generator power source. Current flows through a water-cooled copper induction coil and suscepts on a thin metal tube, which is also the outer boundary of the cooling gas annular passage. The susceptor radiates heat to the vessel wall, which in turn transfers heat to the fluidized bed. The induction coil has two zones to allow heating of deep and shallow beds.

\subsubsection{Cooling System}

Cooling air is provided by a rotary blower. The air passes into the annulus between the vessel and susceptor via two intake plenums and leaves via a central exhaust plenum.

\subsubsection{Gas Distributor}

The gas distributor is a Hastelloy $\mathrm{X}$, perforated, 90-deg cone with a $0.025-\mathrm{m}$ opening at the vertex. Fluidizing gas enters through the vertex opening and a plenum surrounding the cone.

\subsubsection{Fines Recycle System}

Particulates that are entrained in the off-gas from the fluid-bed vessel are separated from the gas by a cyclone and 21 sintered metal filters. The sintered metal filters are alternately blown back to 
discharge the solids into the filter containment vessel. The solids from the cyclone and filter vessel are metered into a common line for reentry into the fluid bed via gravity flow. The fines recycle line and the fresh feed line are connected to provide a single entry point to the bed.

\subsubsection{Product Removal System}

The product removal system consists of a variable-width $0.05 \mathrm{~m}$ knifegate valve to regulate the flow of product into a pneumatic transport line.

\subsection{AIR CLASSIFIER}

\subsubsection{General Description}

The burned-back fissile and fertile fuel particles are separated in an air classification system which consists of a feed system, zigzag column, off-gas filtration system, and product bunkers.

A brief description of these components follows. A more detailed description of the components and their development prior to the initial pilot plant sequential operation is given in Ref. 3-7. An evaluation of the design appears in Ref. 3-8. The entire system is shown in Fig. 3-5; the zigzag column is shown in more detail in Fig. 3-6.

\subsubsection{Feed System}

The feed system consists of a bunker, knifegate valve, and vibratory feeder. The bunker stores the burned-back particles after pneumatic transport from the large primary burner product bunker. The knifegate valve provides a positive airlock between the bunker and the classifier column. The vibratory feeder is variable speed to allow adjustment of the feed rates. 


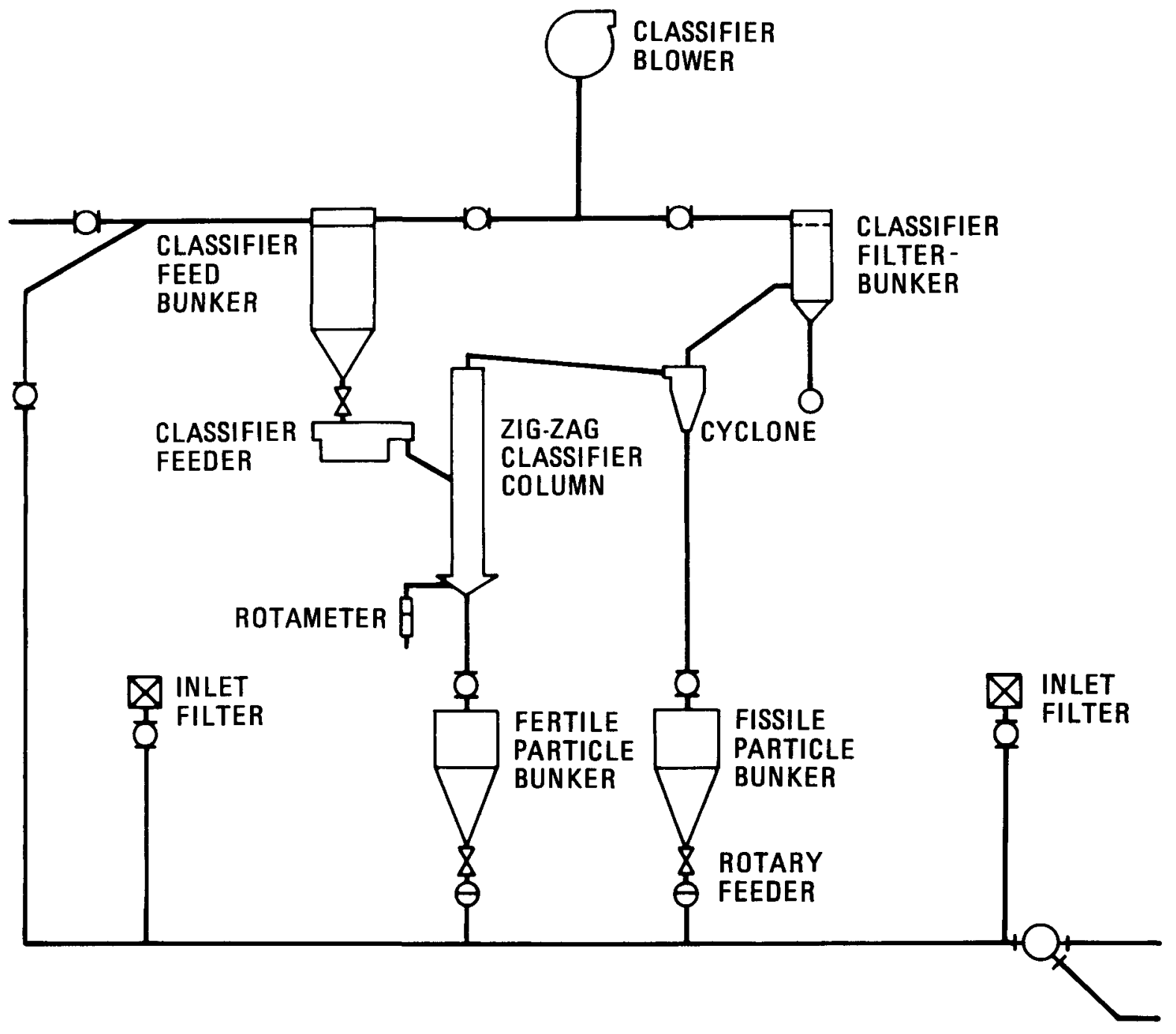

Fig. 3-5. Fuel particle classification system 


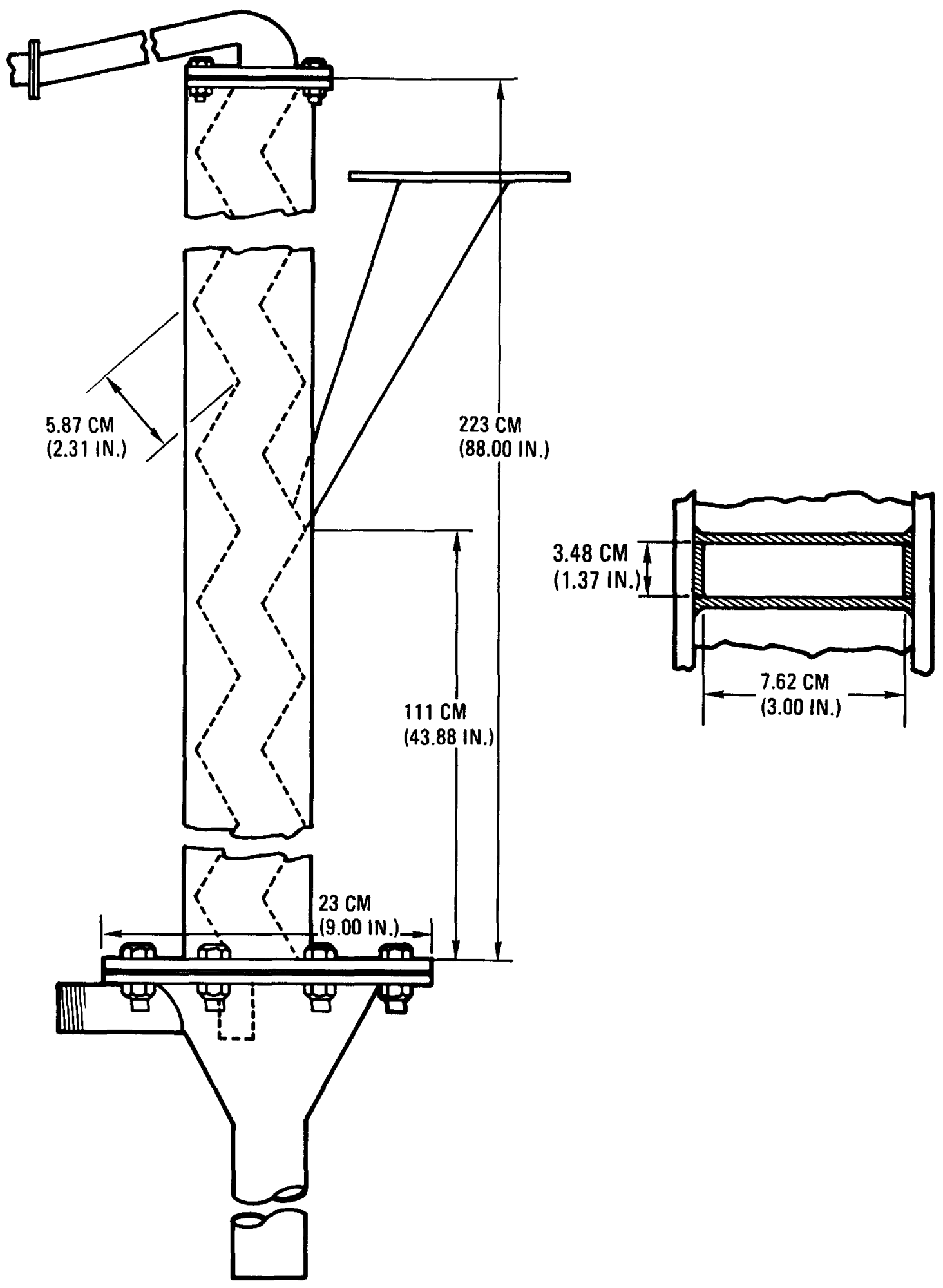

Fig. 3-6. Zig-zag classifier column 


\subsubsection{Zigzag Column}

Classification of the fuel particles is accomplished in a 2.2-m-long stainless steel zigzag column with a $3.5-\mathrm{cm}$ by $7.6-\mathrm{cm}$ cross section and a feed inlet at the midpoint.

\subsubsection{Off-Gas Filtration System}

Particles that are entrained in the gas stream are separated from the gas by a cyclone and six sintered metal filters. The sintered metal filters are alternately blown back to discharge the solids into the filter containment vessel. The solids from the cyclone discharge into the fissile product bunker. The solids from the filter chamber are discharged separately.

\subsubsection{Product Bunkers}

Material passing downward through the zigzag column is collected in the fertile product bunker. Both the fertile and fissile product bunkers are 60-deg cone-bottomed stainless steel vessels with knifegate and rotary valves for discharge into a pneumatic transport system.

\subsection{FUEL PARTICLE CRUSHER}

\subsubsection{General Description}

Fracture of the TRISO coatings on the fissile particles is accomplished in a double-roll crusher. The gap between the rolls is sized to fracture the coatings without crushing the particles to an extent that produces difficulty in fluidizing the product.

A brief description of the system follows. A more detailed description appears in Ref. 3-9. A detailed description of the system development 
prior to the initial pilot plant sequential operation is given in Ref. 3-10. An evaluation of the design is presented in Ref. 3-11. The system is illustrated in Fig. 3-7; details of the crusher assembly are shown in Fig. 3-8.

\subsubsection{Crushing System}

The crusher is choke fed from a hopper that discharges through a knifegate valve. The crusher assembly consists of a dust-tight housing two $0.10-\mathrm{m}-1$ long hardened steel rolls mounted on precision-tapered roller bearings, and two meshed spur gears. The rolls are driven by a singlespeed 1492-W (2-hp) ac motor. The motor is directly connected to a speed reducer and to a pinion gear that drives one of the two meshed spur gears to produce a roll speed of $\sim 40 \mathrm{rpm}$. The crusher product gravity discharges directly into the crushed particle fluid-bed burner feed hopper.

\subsection{CRUSHED FUEL PARTICLE FLUID-BED BURNER - SECONDARY BURNER}

\subsubsection{Genera1 Description}

Combustion of the inner carbon coatings and conversion of the uranium oxycarbide to oxides of uranium is accomplished in a fluid-bed burner system consisting of a feed system, fluid-bed vessel with integral filters, heating and cooling systems, gas distributor, and product removal system.

A brief description of these components follows. A detailed description is given in Ref. 3-12. A detailed description of the system development prior to the initial pilot plant sequential operation appears in Ref. 3-13. An evaluation of the design is given in Ref. 3-14. The entire system is shown in Fig. 3-9; the burner assembly is shown in more detail in Fig. 3-10. 


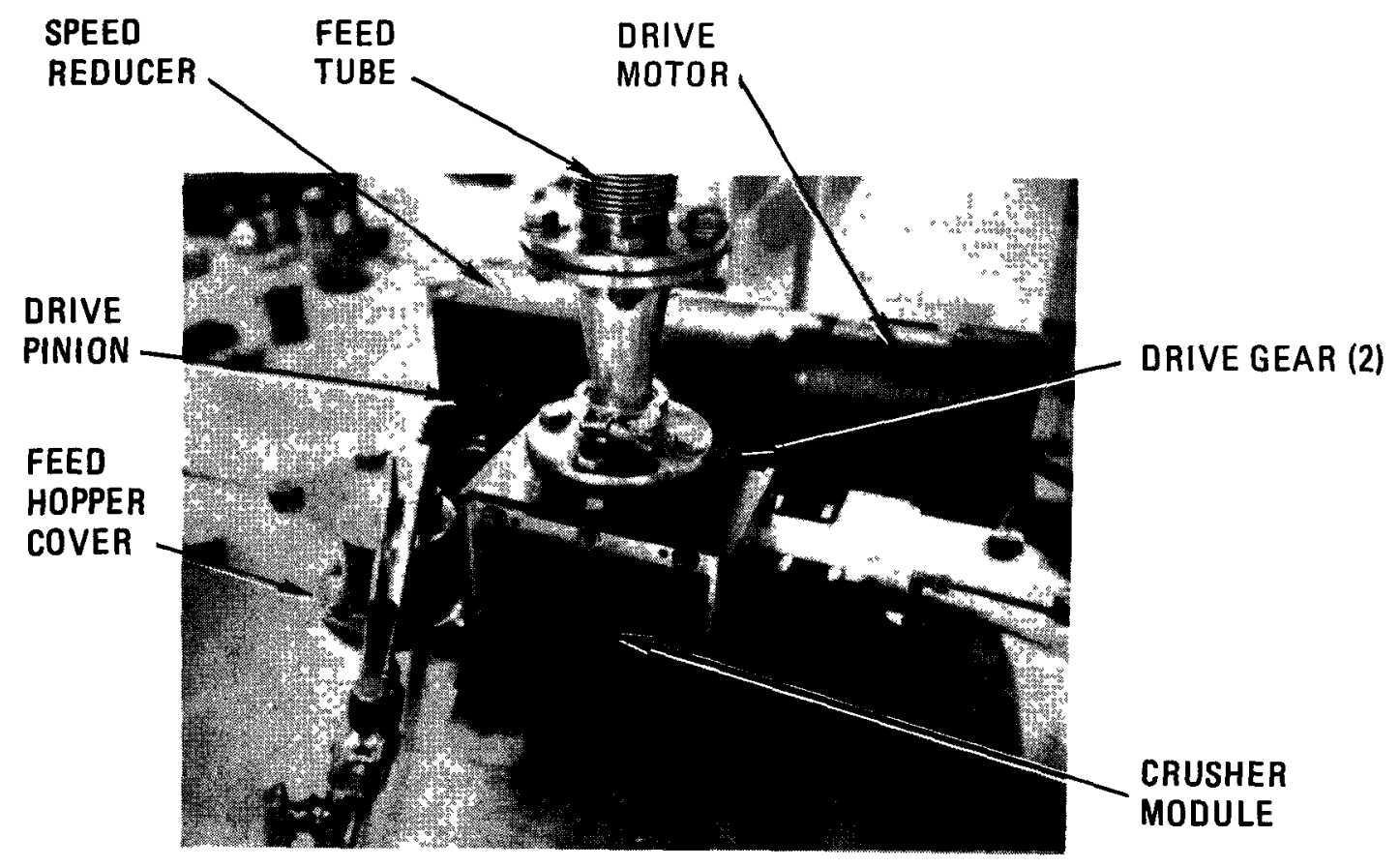

Fig. 3-7. Fuel particle crusher and drive motor (mounted on 20-cm secondary burner hopper) 

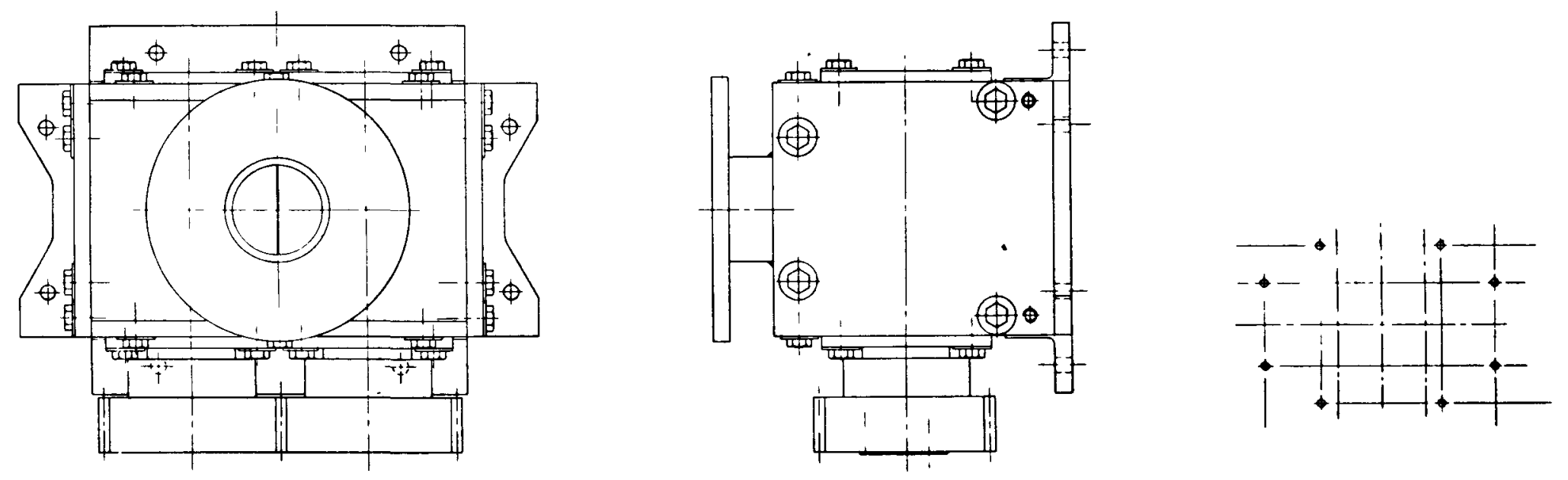

$\underset{\infty}{\stackrel{\omega}{1}}$
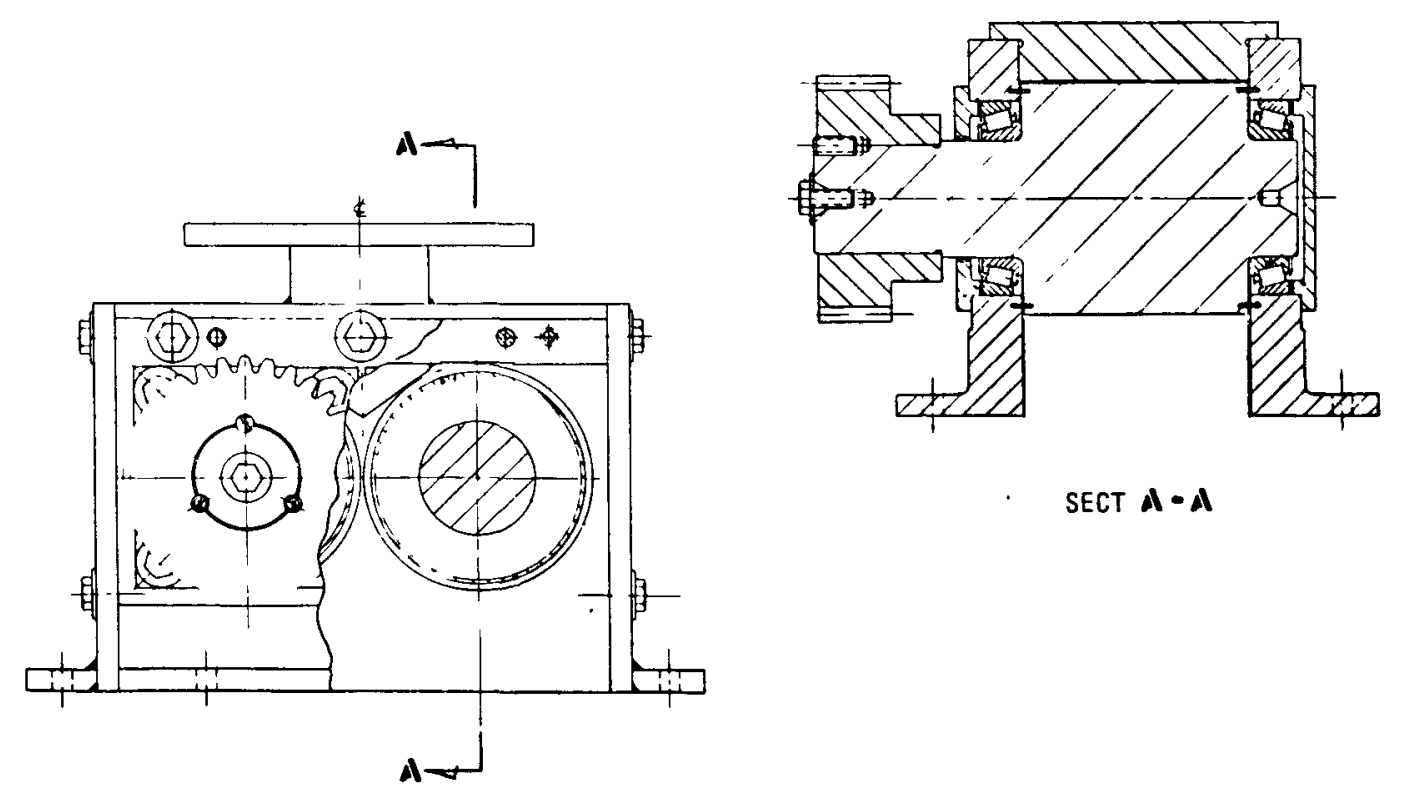

Fig. 3-8. Fuel particle crusher 

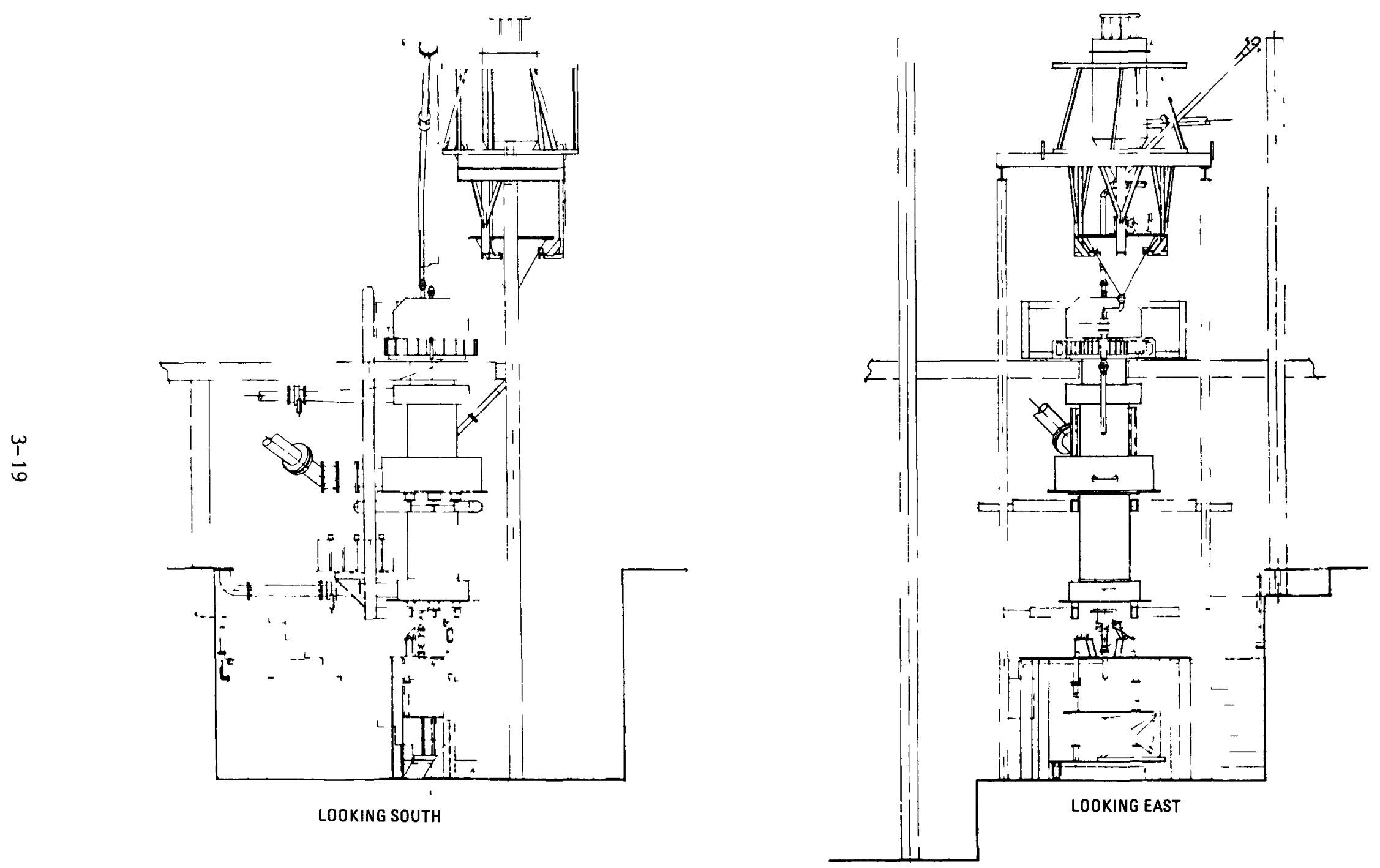

Fig. 3-9. Secondary burner system 


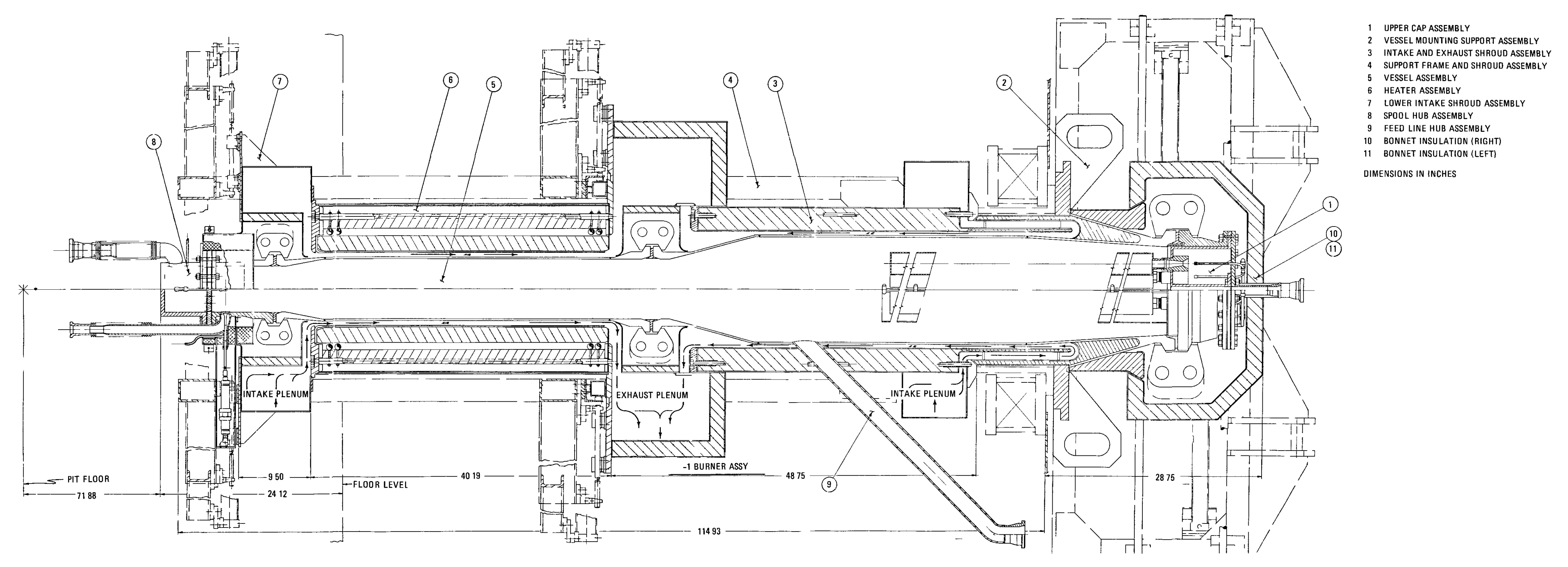

Fig. 3-10. Cross section of $0.20-\mathrm{m}$ secondary burner system 


\subsubsection{Feed System}

The crushed fuel particles are batch fed from a bunker located above the burner. The bottom of the bunker empties into a double-elbow pipe arrangement which is an angle-of-repose type feeder. A nitrogen purge, located at the first elbow, sweeps the material into the burner vessel. Another nitrogen purge aimed at the corner of the first elbow provides for complete cleanout. The bunker is isolated from the burner by a ball valve located beneath the angle-of-repose feeder.

\subsubsection{Fluid-Bed Vessel and Integral Filters}

The entire fluid-bed vessel is $3.4 \mathrm{~m}$ long. The fluid-bed section is $1.3 \mathrm{~m}$ long with a $0.20-\mathrm{m}$ internal diameter. This section attaches to a section $1.7 \mathrm{~m}$ long which tapers outward to $0.35-\mathrm{m}$ internal diameter. The top section houses six sintered metal filters and provides for disengagement of the solids from the gas by reducing the superficial velocity. The remaining entrained solids are removed by the filters, which are alternately blown back, two at a time, to return the solids to the bed. Above the filters and integral with the gas distributor section are gas plenums, which comprise the remaining overall length of the vessel. All components are constructed of Hastelloy $\mathrm{X}$.

\subsubsection{Heating System}

The fluid-bed vesse1, as the primary burner, is heated by induction with a motor generator power source. However, the secondary burner requires only a single zone heater.

\subsubsection{Cooling System}

Cooling air is provided by a rotary blower. The system is similar in concept to that of the primary burner except cooling pin fins are not required. 


\subsubsection{Gas Distributor}

The gas distributor is a perforated, flat, Hastelloy $\mathrm{X}$ plate. The holes are distributed evenly with a triangular pitch to provide an even solid-circulation pattern. Beneath the plate is a gas plenum through which the fluidizing gases pass.

\subsubsection{Product Removal System}

The product removal system consists of a modified internal combustion engine valve, which is seated flush with the burner wall just above the gas distributor. The valve is opened and closed via a pneumatic actuator. Product flows through the valve and into a pneumatic transport system. Complete removal of material from the flat distributor plate is accomplished by a sweep tube that impinges high-pressure gas through a series of small holes onto the plate to levitate the remaining solids.

\subsection{SOLIDS HANDLING SYSTEMS}

\subsubsection{General Description}

Movement of solid products to the subsequent process step between the various unit operations within the cold pilot plant is accomplished by vacuum pneumatic transport systems. These systems include transport of crushed fuel elements (Uniframe product) to a storage bunker and from the storage bunker to the primary burner feed bunker, transport of burnedback fuel particles (primary burner product) to a storage bunker and from the storage bunker to the air classifier feed bunker, transport of fertile fuel particles to a storage bunker, transport of fissile fuel particles to the particle crusher feed bunker, and transport of burned-back crushed TRISO fuel particles (secondary burner product) to a storage bunker. The capability of recycling materials within a process step is also provided for some operations. Generally, product samplers are also located within the transport systems. 
A typical transport system is shown in Fig. 3-11. The motive gas is pulled through a HEPA filter to avoid product contamination or escape via backflow. Product material is gravity fed into the conveying line downstream of the filter. Either an orifice or a rotary valve controls the feed rate into the conveying line. Conveying lines are sized according to the product being conveyed. The lines are in manageable sections that are joined together with food-industry-type sanitary clamps. Bends are gradual, and the first bend is placed as far downstream as possible to allow acceleration of the solids. At the end of each line there is a bunker isolation valve, a bellows (to allow bunker weighing), and an expanded line section for solids deceleration. The lines enter a bunker tangentially to avoid perpendicular impingement of the solids on the bunker wall.

The bunker is protected from overpressure and underpressure by pressure relief valves. Sintered metal filters in the bunker separate the entrained solids from the conveying gas. The filters are alternately blown back to discharge the solids for collection in the bunker. A load cell system allows continuous monitoring of the weight of material in the bunker. The bunker is also equipped with a level sensor to detect when the maximum capacity has been reached. The fixed-speed positivedisplacement rotary blower is mounted downstream of the bunker.

A detailed description of these systems, their components, and the system development prior to the initial pilot plant sequential operation is given in Ref. 3-15. An evaluation of their initial performance appears in Ref. 3-16, and an evaluation of the design is given in Ref. 3-8.

REFERENCES

3-1. Strand, J. B., J. W. Baer, and E. J. Cook, "Uniframe Interim Design Report," DOE Report GA-A14645, General Atomic Company, December 1977. 


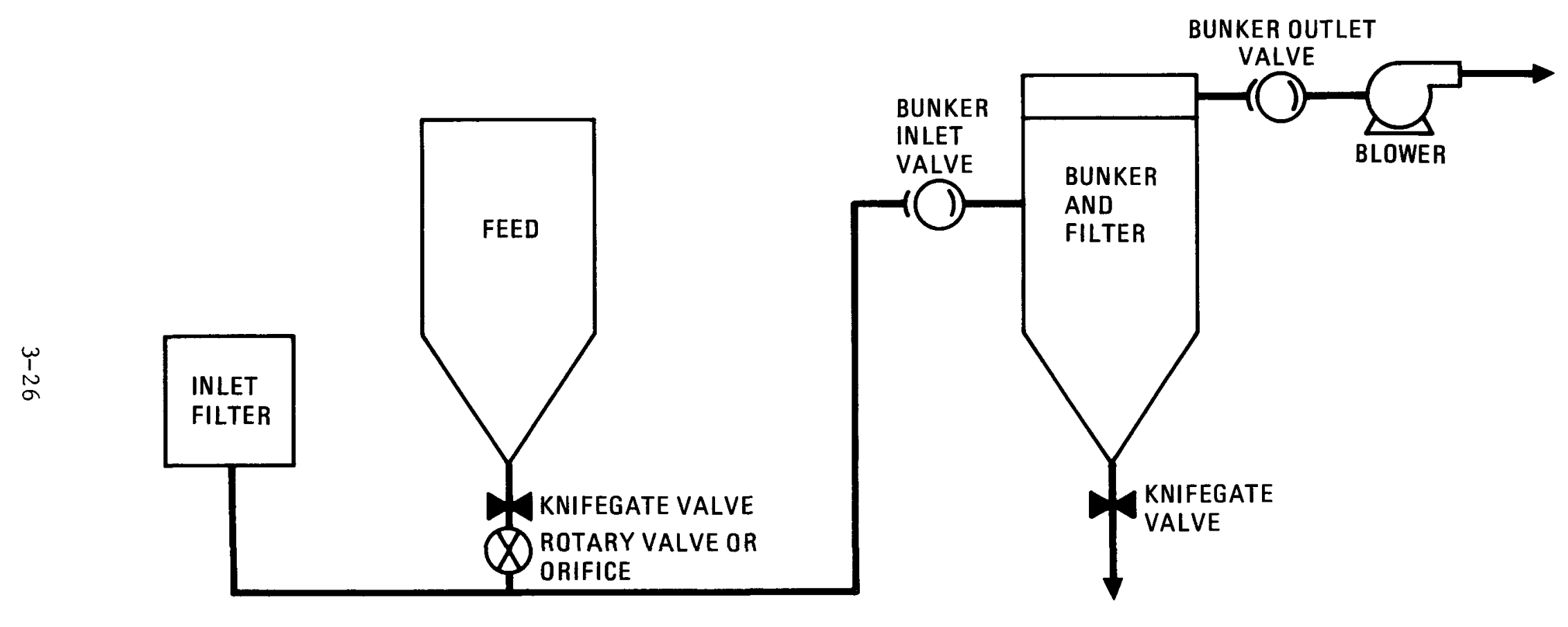

Fig. 3-11. Typical transport system 
3-2. Strand, J. B., and G. T. Cramer, "HTGR Fuel Element Size Reduction System - Interim Development Report," DOE Report GA-A14838, General Atomic Company, June 1978.

3-3. Strand, J. B., "Design Evaluation of the HTGR Fuel Element Size Reduction System," DOE Report GA-A14859, General Atomic Company, June 1978 .

3-4. Steeger, E. J., and C. A. Kergis, "0.40-Meter Primary Burner Design Report," DOE Report GA-A14913, General Atomic Company, to be published.

3-5. Young, D. T., "Process Development Report: 0.40-m Primary Burner System," DOE Report GA-A14816, General Atomic Company, April 1978.

3-6. Rode, J. S., "A Design Evaluation of the 40-cm (16-in.) Primary Burner System," DOE Report GA-A14452, General Atomic Company, June 1977.

3-7. Strand, J. B., "Particle Classifier for HTGR Fuel Reprocessing Engineering Scale Unit Interim Development Report," DOE Report GA-A14930, General Atomic Company, July 1978.

3-8. McNair, J. M., "Design Evaluation, Solids Handling and Air Classifier," DOE Report GA-A14860, General Atomic Company, to be pub1ished.

3-9. Baer, J. W., J. B. Strand, E. J. Cook, and C. M. Miller, "Interim Design Report: Fuel Particle Crushing," DOE Report GA-A14675, General Atomic Company, November 1977.

3-10. Baer, J. W., and J. B. Strand, "Interim Development Report: Engineering-Scale HTGR Fuel Particle Crusher," DOE Report GA-A15073, Genera1 Atomic Company, September 1978.

3-11. Johanson, N. W., "HTGR Fuel Particle Crusher Design Evaluation," DOE Report GA-A14957, Genera1 Atomic Company, October 1978.

3-12. Steeger, E. J., and J. B. Strand, "Interim Design Report: HTGR Fuel Reprocessing Engineering Scale 0.2-m Secondary Burner," DOE Report GA-A14942, General Atomic Company, to be published.

3-13. Rickman, W. S., "Process Development Report - 0.20-m Secondary Burner System," DOE Report GA-A14542, General Atomic Company, September 1977. 
3-14. Rode, J. S., "A Design Evaluation of the 20-cm (8-in.) Secondary Burner System," DOE Report GA-A14510, General Atomic Company, August 1977.

3-15. Cook, E. J., and J. M. MCNair, "Solids Transport System for HTGR Fuel Reprocessing: Interim Development Report," DOE Report GA-A14958, General Atomic Company, to be published.

3-16. Cook, E. J., and P. C. Richards, "Initial Performance Evaluation of Major Components in the Head-End Reprocessing Solids Handling System," DOE Report GA-A14508, General Atomic Company, September 1977. 


\section{INITIAL SEQUENTIAL OPERATION}

\subsection{BACKGROUND}

Individual tests performed with the major equipment within the cold pilot plant used feed materials that were typical but not necessarily identical to those expected from the preceding operation. The major reasons for this were the high cost of fuel elements and particles and the unavoidable delays that would be incurred by the dependence of tests on feed from testing of the preceding operation. Therefore, to obtain information from the maximum number of tests on individual equipment items, stand-in and substitute feed materials were used. For the Uniframe, this included unfueled graphite elements and scrap graphite (Ref. 4-1). For the primary burner, made-up blends of fuel particles and crushed graphite were used (Ref. 4-2). For the air classifier, blends of burned-back fissile and fertile fuel particles of varying compositions were tested (Ref. 4-3). Separate tests on crushing of fissile and fertile fuel particles were completed with the particle crusher (Ref. 4-4). Secondary burning of fissile and fertile fuel particles was accomplished on batches without graphite contamination (Ref. 4-5). Transport tests were done with made-up blends resembling the expected products (Ref. 4-6).

These feed materials proved satisfactory for determining the operating characteristics and capabilities of the pilot plant equipment and processes. However, to accurately assess the effects and interactions between processes, tests were also planned in which the pilot plant equipment would be operated sequentially. This would provide additional data on particle breakage within a single process; the effects of the preceding process on particle breakage; cumulative particle breakage in the cold head-end processes; effects on fluidization, combustion, and material accountability; and separability of fissile and 
fertile fuel particles that contain broken particles and residual graphite. The initial sequential operation of the pilot plant systems was completed in September 1977. Following is a summary of the operations and results; a complete description is given in Ref. 4-7.

\subsection{FUEL ELEMENT SIZE REDUCTION}

The sequential operations began with the crushing of 20 standard fuel elements in the Uniframe system. The first three elements were sampled individually by collecting and splitting the entire product from the screener and oversize crusher. The products from these elements were placed in barrels, then individually transported at $\sim 18 \mathrm{~m} / \mathrm{s}$ average conveying velocity to the crusher product bunker and the primary burner feed bunker. The products were sampled again by a cross-cutting sampler as they left the crusher product bunker. The analyses of the product size distributions and fuel particle breakages were compared before and after transport, and no significant differences were detected.

The next four elements were individually crushed and transported to the crusher product and primary burner feed bunkers. One was transported at $\sim 18 \mathrm{~m} / \mathrm{s}$ average conveying velocity, the others at $\sim 25 \mathrm{~m} / \mathrm{s}$. Each was sampled by the cross-cutting sampler. As expected, fuel particle breakage was increased at the higher velocity.

The next six elements were crushed in rapid succession and combined in the product bunker. The total time required for crushing these six elements was $42 \mathrm{~min}$. During the normal cleanout period after crushing, bearing overheat on the secondary crusher forced its shutdown. Because of the overheating, the remaining size-reduction operations were spaced to allow cooling of the bearing. The last seven elements were individually crushed and transported to the product bunker. All of the final 13 fuel elements crushed were transported to the product bunker at an average gas velocity of $\sim 25 \mathrm{~m} / \mathrm{s}$, because transport was somewhat unreliable 
at $\sim 18 \mathrm{~m} / \mathrm{s}$. The combined crushed products of these final elements were transported to the primary burner feed bunker as needed and were sampled during transport by the cross-cutting sampler. Fuel particle breakage was similar to that of the other crushed fuel elements that were individually transported at the $\sim 25 \mathrm{~m} / \mathrm{s}$ average conveying velocity.

These operations indicated the need for controlling the feed rate of crushed product into the transport line to allow the lower conveying velocity to be used. Therefore, it was planned to install and test a rotary feed valve at the screener discharge prior to the next sequential operation. Also indicated is the need for improved lubrication for the jaw crusher pitman bearings.

\subsection{CRUSHED FUEL ELEMENT BURNING}

During the initial sequential operation, a pneumatic injection system rather than a gravity recycle system was used to return elutriated fines to the fluid bed of the primary burner. This system is shown schematically in Fig. 4-1. The fines are removed from the off-gases by a cyclone and sintered metal filters. Material from the cyclone and filters discharged into a common line that fed two bunkers. The bunkers were alternately filled and pressurized. Fines from the pressurized bunker were metered into a pipe and injected into the burner vesse1 along with additional oxygen for combustion.

The initial attempt at combustion of the crushed fuel element material was shut down after $\sim 3 \mathrm{~h}$ of burning because a bellows in the fines $/ \mathrm{O}_{2}$ injection line ruptured. The bellows was replaced by a straight pipe, and combustion was restarted. Combustion continued for another $28 \mathrm{~h}$ without problems. At that time, a fines leak occurred at the top of the burner thermowell. Fines recycle was stopped during repair of the leak and then restarted. After the last of the crushed product from the 20 fuel elements had been fed, a fines leak occurred at the pipe $Y$ that 


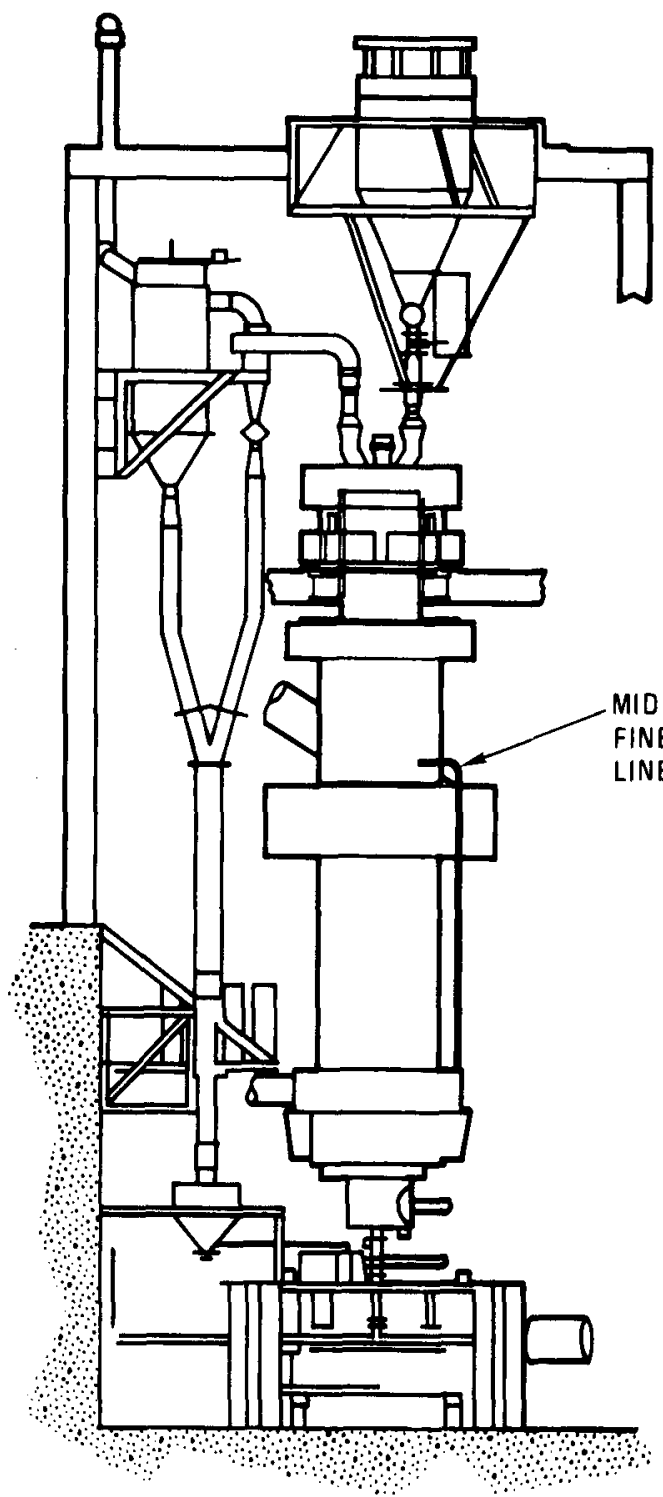

LOOKING EAST

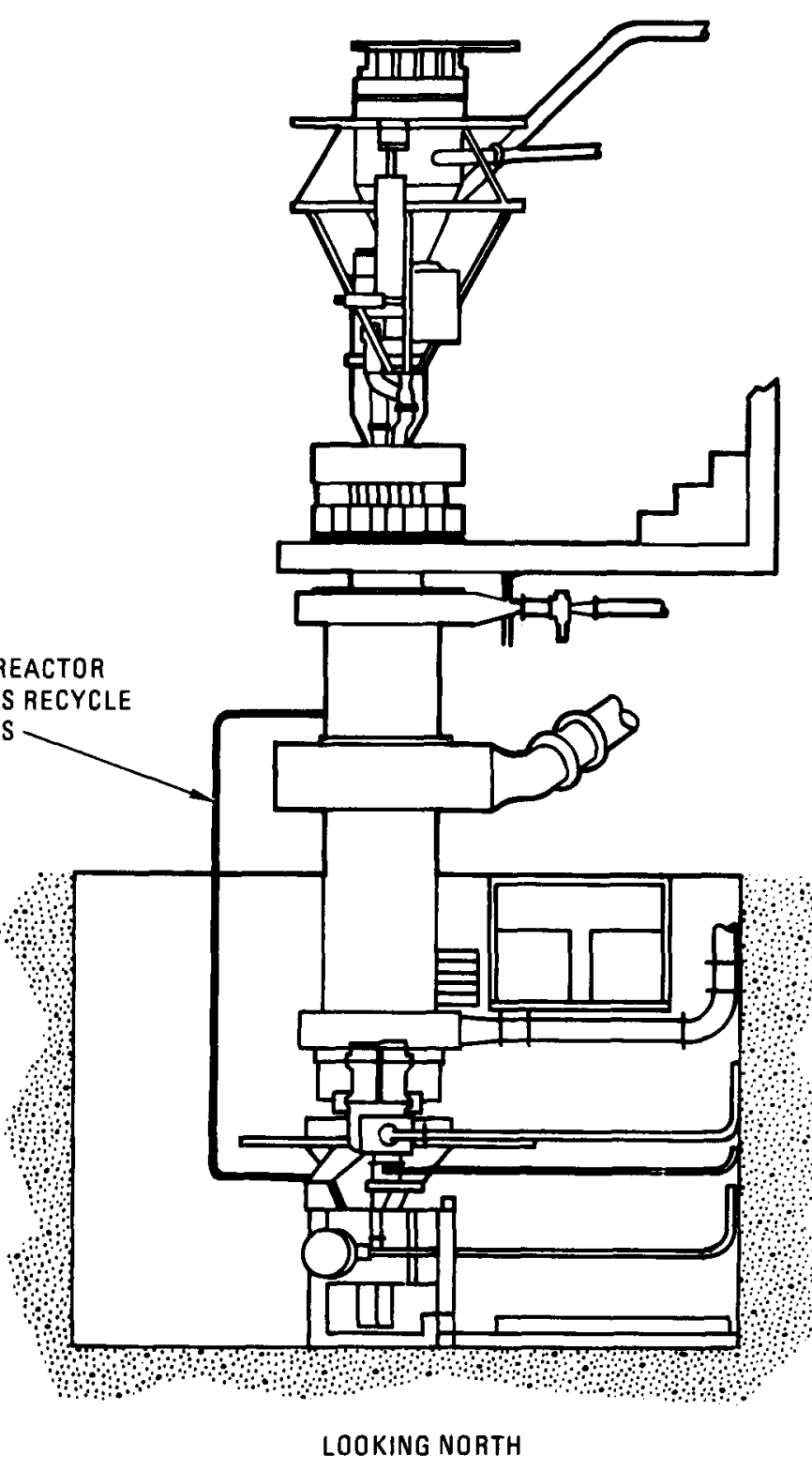

LOOKING NORTH

Fig. 4-1. Primary burner with pneumatic fines recycle system 
joins the two fines bunkers with the common injection pipe. Fines recycle was stopped but combustion was continued. Two hours later the thermowell was severed Inside the burner vessel from erosion due to the high-velocity fines stream. The run was terminated because bed temperature monitoring was no longer possible.

After cooling to $4400^{\circ} \mathrm{C}$, pneumatic transport of the bed to the product bunker was begun. After $\sim 152 \mathrm{~kg}$ had been transported, the broken thermowell obstructed the burner outlet and transport was stopped. The remainder of the material in the burner tube was removed by vacuum from the top of the burner. The material that had fallen through the gas distributor holes into the plenum was also removed by vacuum. The total carbon content of the final bed was approximately $30 \mathrm{wt} \%$. The total fines inventory in the two bunkers was $14.8 \mathrm{~kg}$.

\subsection{PARTICLE CLASSIFICATION}

Air classification of the primary burner products was accomplished in three batches. The first consisted of part of the primary burner product that was removed through the pneumatic transport system. The second consisted of the remainder of the product removed through the transport system plus the material vacuumed from the plenum. The third consisted of the material vacuumed through the top of the burner vessel after it had been screened to remove the coarse $(+869-\mu \mathrm{m})$ and fine $(-412-\mu \mathrm{m})$ predominately graphite fractions from the particle size material. In all three tests a classifying gas velocity of $6.0 \mathrm{~m} / \mathrm{s}$ and $100 \%$ capacity of the vibratory feeder were used.

Crossover in all three parts of the classification was greater than in the previous tests using blends of particles. Microscopic examination of material from the fissile stream revealed that the fertile material in that stream was predominately broken particles, as was expected. Overall, heavy metals in the fertile stream were 1.0 wt \% uranium and $99.0 \mathrm{wt} \%$ 
thorium. Heavy metals in the fissile stream were 64.0 wt \% uranium and 36.0 wt \% thorium. Crossover of fissile material to the fertile stream was acceptable; however, crossover of fertile material to the fissile stream was excessive.

\subsection{PARTICLE CRUSHING}

Following classification, $49.3 \mathrm{~kg}$ of the material from the fissile stream was crushed in the fuel particle crusher at $240 \mathrm{rpm}$ roll speed as feed for the secondary burning operation. The composition of this material was 9 wt \% carbon, 6 wt $\% \mathrm{ThO}_{2}$, and 85 wt \% TRISO fissile particles.

\subsection{CRUSHED FUEL PARTICLE BURNING}

The crushed fuel particles were added to the secondary burner through the angle of repose feeder in about $4 \mathrm{~min}$. Bed heat-up to ignition temperature took about $50 \mathrm{~min}$. At that point, oxygen was introduced and ramped to $70 \%$ of the inlet gas in about $20 \mathrm{~min}$. This was held constant for about $100 \mathrm{~min}$; then the oxygen was gradually reduced to keep the off-gas at less than $20 \%$ oxygen. For the final 20 min of the run, the total gas velocity was reduced to $0.45 \mathrm{~m} / \mathrm{s}$ to allow residual carbon on the filters to reenter the bed for combustion. The total time from ignition to complete combustion was about $3 \mathrm{~h} 45 \mathrm{~min}$.

The product was cooled to $100^{\circ} \mathrm{C}$ and pneumatically transported to the product bunker. The total product was $32.2 \mathrm{~kg}$ and contained 0.2 wt \% carbon and less than 0.5 wt \% unbroken fuel particles.

\subsection{OVERALL MATERIAL BALANCE}

The combined weight of the 20 fuel elements was $2448.8 \mathrm{~kg}$. They contained $301.493 \mathrm{~kg}$ of fertile and $106.095 \mathrm{~kg}$ of fissile particles. 
Upon completion of the sequential operations, $298.23 \mathrm{~kg}$ or $98.9 \%$ of the fertile and $104.38 \mathrm{~kg}$ or $98.3 \%$ of the fissile particles were accounted for in the final products and samples taken during testing.

\subsection{OVERALL PARTICLE BREAKAGE}

Since broken particles contribute greatly to crossover during classification, the quantity of particles broken by crushing, primary burning, and pneumatic transport until the particles reach the classifier feed is very important. The overall particle breakage after classification was calculated to be $6.6 \%$ and $22.5 \%$ of the fertile and fissile particles, respectively. However, this did not include broken particles in products that were not classified. Since the majority of the breakage occurred during the primary burning portion of the operations, these figures are probably very conservative.

Reduction in particle breakage for the next sequential operation was to be achieved via the following improvements: (1) better control of crusher product feed rates to the conveying system, (2) reduction of materials entering the primary burner gas plenum, and (3) implementation of a gravity fines recycle system on the primary burner.

\section{REFERENCES}

4-1. Strand, J. B., and G. T. Cramer, "HTGR Fuel Element Size Reduction System - Interim Development Report," DOE Report GA-A14838, General Atomic Company, June 1978.

4-2. Young, D. T., "Process Development Report: 0.40-m Primary Burner System," DOE Report GA-A14816, General Atomic Company, April 1978.

4-3. Strand, J. B., "Particle Classifier for HTGR Fuel Reprocessing Engineering-Scale Unit Interim Development Report," DOE Report GA-A14930, General Atomic Company, July 1978.

4-4. Baer, J. W., and J. B. Strand, "Interim Development Report: Engineering-Scale HTGR Fuel Particle Crusher," DOE Report GA-A15073, General Atomic Company, September 1978. 
4-5. Rickman, W. S., "Process Development Report - 0.20-m Secondary Burner System," DOE Report GA-A14542, General Atomic Company, September 1977.

4-6. Cook, E. J., and J. M. McNair, "Solids Transport System for HTGR Fue1 Reprocessing: Interim Development Report," DOE Report GA-A14958, General Atomic Company, to be published.

4-7. "The General Atomic HTGR Fue1 Reprocessing Pilot Plant: Results of Initial Sequential Equipment Operation," DOE Report GA-A15081, General Atomic Company, September 1978. 


\section{SECOND SEQUENTIAL OPERATION}

5.1. FEED MATERIAL

A total of 20 standard LHTGR fuel elements were used in the second cold pilot plant sequential operation. Each fuel element contained 1632 fuel rods composed of TRISO coated fissile fuel particles fabricated with depleted uranium by a weak acid resin (WAR) process and BISO coated $\mathrm{Th}_{2}$ fertile fuel particles. The 20 elements contained $279.752 \mathrm{~kg}$ of thorium and $18.168 \mathrm{~kg}$ of uranium. The combined weight of the elements was 1468.9 $\mathrm{kg}$. The heaviest weighed $125.1 \mathrm{~kg}$, and the lightest $121.3 \mathrm{~kg}$. Individual fuel element weights and their thorium and uranium content are given in Table 5-1.

\subsection{FUEL ELEMENT SIZE REDUCTION}

\subsubsection{Equipment Changes}

Two modifications were made to the Uniframe after the initial sequential operation. A rotary valve was added at the discharge of the screener, and prelubrication systems were added to the pitman bearings of the primary and secondary crushers. The rotary valve was installed to provide a constant feed rate from the crusher to the transport system so that transport velocities and, therefore, particle breakage could be minimized. The prelubrication systems were installed to provide lubrication to the pitman bearings at startup.

\subsubsection{Crushing}

The first six fuel elements were individually crushed and transported to the crusher product bunker. The next four elements were crushed in rapid succession over a span of $24 \mathrm{~min}$. The remaining ten 
TABLE 5-1

LHTGR STANDARD FUEL ELEMENTS USED IN SECOND SEQUENTIAL OPERATION

\begin{tabular}{|c|c|c|c|}
\hline $\begin{array}{c}\text { Fue1 } \\
\text { Element } \\
\text { No. } \\
\end{array}$ & $\begin{array}{c}\text { Total } \\
\text { Weight } \\
\text { (kg) }\end{array}$ & $\begin{array}{c}\text { Thorium } \\
\text { Content } \\
\text { (kg) }\end{array}$ & $\begin{array}{c}\text { Uranium } \\
\text { Content } \\
(\mathrm{kg})\end{array}$ \\
\hline $482-46$ & 122.4 & 13.361 & 0.909 \\
\hline $482-127$ & 123.3 & 13.526 & 0.909 \\
\hline $482-98$ & 124.5 & 14.440 & 0.907 \\
\hline $438-80$ & 124.5 & 14.623 & 0.909 \\
\hline $438-31$ & 124.0 & 13.526 & 0.909 \\
\hline $482-59$ & 123.8 & 13.965 & 0.909 \\
\hline $482-49$ & 123.8 & 14.440 & 0.909 \\
\hline $478-23$ & 124.9 & 14.440 & 0.907 \\
\hline $438-3$ & 121.7 & 14.623 & 0.909 \\
\hline $482-107$ & 124.7 & 14.440 & 0.909 \\
\hline $482-62$ & 121.7 & 13.252 & 0.909 \\
\hline $482-105$ & 124.4 & 14.623 & 0.909 \\
\hline $482-103$ & 124.2 & 14.440 & 0.907 \\
\hline $482-32$ & 125.1 & 14.440 & 0.907 \\
\hline $482-31$ & 121.5 & 13.252 & 0.909 \\
\hline $482-149$ & 122.4 & 13.252 & 0.909 \\
\hline $482-87$ & 122.2 & 13.252 & 0.909 \\
\hline $482-16$ & 124.7 & 14.440 & 0.907 \\
\hline $438-13$ & 123.8 & 14.257 & 0.907 \\
\hline $438-29$ & 121.3 & 13.160 & 0.907 \\
\hline Totals & 2468.9 & 279.752 & 18.168 \\
\hline
\end{tabular}


elements were also crushed in this manner but only in the quantity required as feed for the primary burner. During the crushing of these elements, the next element was charged as soon as the preceding crushed product had cleared the screener. The rotary valve was not started until $30 \mathrm{~s}$ after each block had entered the crusher. This method allowed product to build up in the screener and provided a constant feed rate to the transport system. A rotary valve speed of $40 \mathrm{rpm}$ delivered the feed at a rate of $0.5 \mathrm{~kg} / \mathrm{s}$, which allowed the crushing to be completed before the screener hopper was emptied. The oversize crusher dump valve was opened after the screener hopper was empty. The products were all transported to the product bunker at $\sim 18 \mathrm{~m} / \mathrm{s}$ average conveying velocity.

The individual element identification numbers, weights, and crushing times are given in Table 5-2 in their order of crushing. Crushing times were similar to those in the initial sequential operation.

\subsubsection{Sampling and Results}

The products were sampled with a cross-cutting sampler at the exit of the product bunker as they were being transported to the primary burner feed bunker. A feed rate of $0.25 \mathrm{~kg} / \mathrm{s}$ and a transport velocity of $18 \mathrm{~m} / \mathrm{s}$ were used for all transfers. A continuous sample was taken of each of 14 batch transfers.

The results of the analyses for fuel particle breakage are given in Table 5-3. The overall fissile particle breakage of 8.7 wt $\%$ was higher than the $4.2 \mathrm{wt} \%$ obtained at a transport velocity of $\sim 18 \mathrm{~m} / \mathrm{s}$ and identical to that obtained at $\sim 25 \mathrm{~m} / \mathrm{s}$ in the initial sequential operation. The overall fertile particle breakage of 1.5 wt \% was higher than the 0.5 wt $\%$ at $\sim 18 \mathrm{~m} / \mathrm{s}$ and the 1.0 wt $\%$ at $\sim 25 \mathrm{~m} / \mathrm{s}$ obtained in the initial operation. Since samples could not be taken at the crusher prior to transport, it is not known whether increased breakage is due to a transport or a crushing phenomenon. 
TABLE 5-2

FUEL ELEMENT CRUSHING DATA

\begin{tabular}{|c|c|c|c|c|c|}
\hline $\begin{array}{l}\text { Fuel } \\
\text { Element } \\
\text { No. }\end{array}$ & $\begin{array}{l}\text { Weight } \\
\quad(\mathrm{kg})\end{array}$ & $\begin{array}{l}\text { Primary } \\
\text { Crushing } \\
\quad \text { Time } \\
\quad \text { (d) }\end{array}$ & $\begin{array}{l}\text { Secondary } \\
\text { Crushing } \\
\text { Time } \\
\text { (s) }\end{array}$ & $\begin{array}{c}\text { Charging Time } \\
\text { From Start of } \\
\text { Run } \\
\text { (s) }\end{array}$ & $\begin{array}{c}\text { Time Between } \\
\text { Element Charges } \\
\text { (s) }\end{array}$ \\
\hline $482-46$ & 122.4 & (a) & (a) & (b) & (b) \\
\hline $482-127$ & 123.3 & 45 & 270 & (b) & (b) \\
\hline $482-98$ & 124.5 & 105 & 270 & (b) & (b) \\
\hline $438-80$ & 124.5 & 45 & (a) & (b) & (b) \\
\hline $438-31$ & 124.0 & (a) & (a) & (b) & (b) \\
\hline $482-59$ & 123.8 & (a) & (a) & (b) & (b) \\
\hline $482-49$ & 123.8 & 100 & (a) & 0 & 0 \\
\hline $478-23$ & 124.9 & 104 & (a) & 360 & 360 \\
\hline $438-3$ & 121.7 & 117 & (a) & 720 & 360 \\
\hline $482-107$ & 124.7 & 105 & (a) & 1200 & 480 \\
\hline $482-62$ & 121.7 & 105 & (a) & (b) & (b) \\
\hline $482-105$ & 124.4 & 36 & 285 & 0 & 0 \\
\hline $482-103$ & 124.2 & 105 & 315 & 375 & 375 \\
\hline $438-32$ & 125.1 & 80 & 270 & 840 & 465 \\
\hline $482-31$ & 121.5 & 105 & 270 & 0 & 0 \\
\hline $482-149$ & 122.4 & 60 & 240 & 360 & 360 \\
\hline $482-87$ & 122.2 & 90 & 240 & 720 & 360 \\
\hline $482-16$ & 124.7 & 105 & 240 & 1080 & 360 \\
\hline $438-13$ & 123.8 & 45 & 210 & 1440 & 360 \\
\hline $438-29$ & 121.3 & 90 & 223 & 1860 & 420 \\
\hline
\end{tabular}

\footnotetext{
(a) Not measured.

(b) Fuel element crushed individually.
} 
TABLE 5-3

PARTICLE BREAKAGE IN UNIFRAME TRANSPORT TO CRUSHER PRODUCT BURNER

\begin{tabular}{rrr} 
Sample & $\begin{array}{c}\text { Broken TRISO } \\
(\text { wt } \%)\end{array}$ & $\begin{array}{c}\text { Broken BISO } \\
(\text { wt \%) }\end{array}$ \\
\cline { 2 - 3 } 1 & 7.5 & 1.7 \\
2 & 8.5 & 1.5 \\
3 & 6.7 & 2.2 \\
4 & 8.8 & 1.6 \\
5 & 11.9 & 2.5 \\
6 & 9.4 & 1.6 \\
7 & 8.8 & 1.3 \\
8 & 8.6 & 1.0 \\
9 & 7.4 & 1.3 \\
10 & 10.4 & 1.1 \\
11 & 9.4 & 1.8 \\
12 & 8.2 & 0.9 \\
13 & 9.6 & 1.6 \\
14 & 7.4 & 1.3 \\
Overal1 & & 1.5
\end{tabular}


A composite product size distribution is shown in Fig. 5-1. This size distribution was similar to that obtained in the initial sequential operation.

Each element was weighed on a scale prior to crushing. The total weight of all of the elements was $2468.9 \mathrm{~kg}$. The weight change indicated by the crusher product bunker load cells was monitored each time material was added or removed from the bunker (see Table 5-4). The load cells indicated a total weight gain of $2460.7 \mathrm{~kg}$ during transport to the bunker and a total weight loss of $2464.2 \mathrm{~kg}$ during transport from the bunker. cleanout of the crusher yielded only $0.5 \mathrm{~kg}$ of material. This amount increases the totals above to $2461.2 \mathrm{~kg}$ and $2464.7 \mathrm{~kg}$, respectively, and yields a materials-unaccounted-for (MUF) of $-0.3 \%$ and $0.2 \%$, respectively.

\subsection{CRUSHED FUEL ELEMENT BURNING}

\subsubsection{Equipment Changes}

Several modifications were made to the primary burning system after the initial sequential operation. Many of these were made to improve the operability of the system and all worked well. Two major modifications were made which had a more pronounced impact on the results of the second sequential operation. The gravity fines recycle system, described in Section 3.2.7, was installed to avoid equipment failures and reduce particle breakage, and selected holes in the conical gas distributor were welded closed to minimize material backflow into the gas plenum.

\subsubsection{Burning Operations}

The starting bed, consisting of $200 \mathrm{~kg}$ of the crushed product from the Uniframe, was fluidized with $2300 \mathrm{l} / \mathrm{min}$ of $\mathrm{CO}_{2}$ during heatup. Because bed expansion does not cover the upper coil until the bed is heated to $300^{\circ} \mathrm{C}$, only the lower coil was used up to that point. Then 


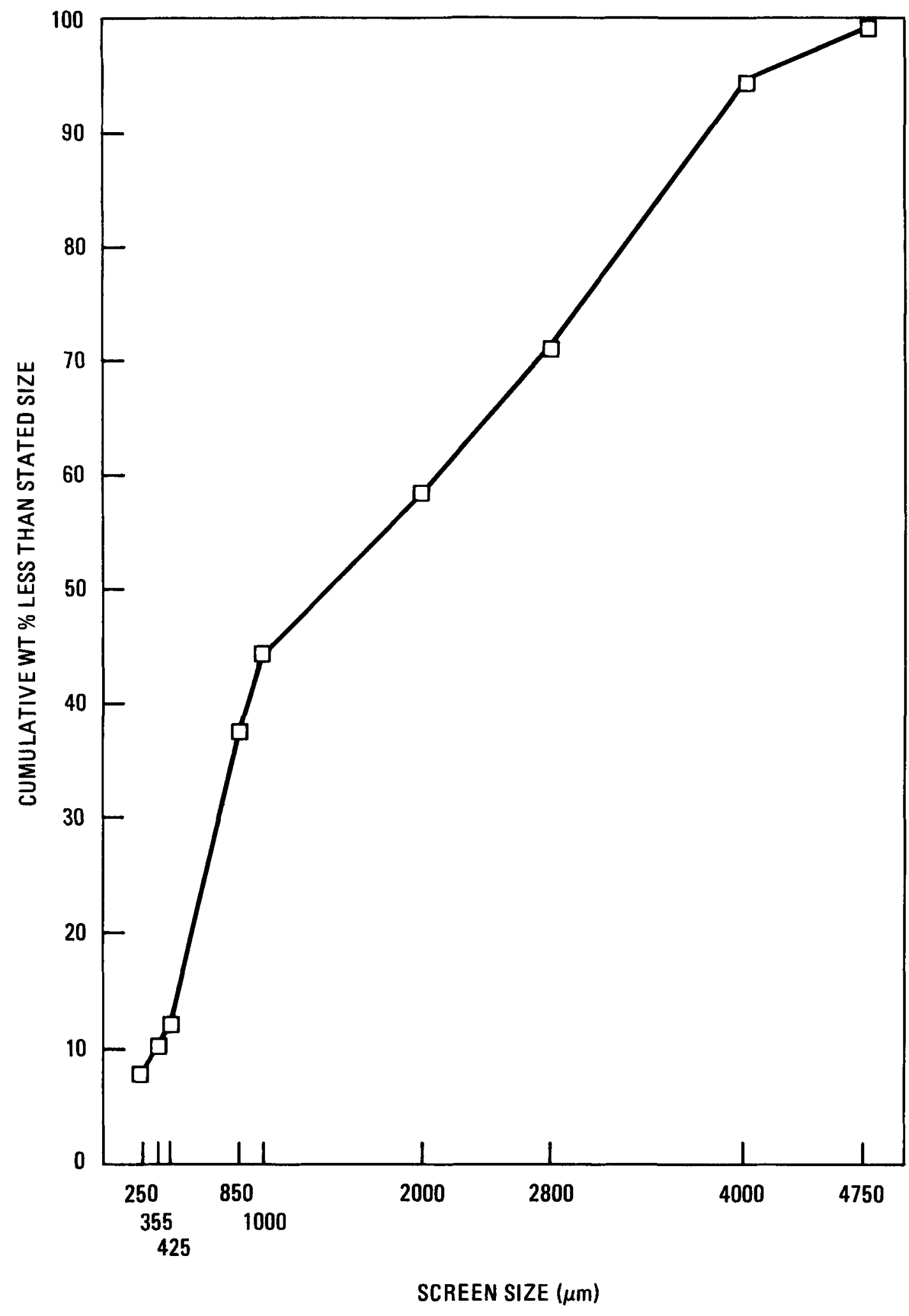

Fig. 5-1. Composite size distribution of crusher product from sequential operation 
TABLE 5-4

CRUSHER PRODUCT BUNKER WEIGHTS RECORDED DURING SEQUENTIAL OPERATION

$\begin{array}{r}\text { Weight of } \\ \text { Element }- \text { Cha } \\ (\mathrm{kg})\end{array}$
122.4
123.3
124.5
124.5
124.0
123.8

123.8
124.9
121.7
124.7

121.7

124.4

124.2

125. 1

121.5

122.4

122.2

124.7

123.8

121.3

$$
624.0^{(a)}
$$

111.9

2460.7

\author{
Weight Loss \\ of Crusher \\ Product Bunker \\ (kg)
}

183.9

191.9

159.3

183.0

189.4

181.3

149.2

182.3

182.2

125.4

179.8

178.5

193.0

185.0

2464.2

(a) Estimated due to bunker overload. 
both coils were actuated to heat to the ignition temperature of $700^{\circ} \mathrm{C}$. At $700^{\circ} \mathrm{C}$, oxygen was introduced at the plenum to ignite the carbon. Flow rates of $>700 \mathrm{l} / \mathrm{m}$ of oxygen were maintained thereafter for carbon combustion.

Fines combustion was initiated after recycling the fines until they were heated to $>400^{\circ} \mathrm{C}$. Fresh feed was continuously added to maintain a minimum of 10 wt \% carbon in the bed. Midreactor oxygen, used to burn the fines, peaked at $360 \mathrm{l} / \mathrm{m}$ during the first $18 \mathrm{~h}$ of the run; after that, flows of only $2200 \mathrm{l} / \mathrm{m}$ were required. This indicated that the recycling fines inventory was low and only newly generated fines were being burned. Above-bed temperatures also declined as the fines inventory decreased.

Combustion was concluded after the crushed product from the first ten fuel elements had been charged so that an interim product removal could be effected. Fuel particle inventory in the bed was raised to $>200 \mathrm{~kg}$ during this time span. This was sufficient for an inductionheated bed carbon burnout.

After cooling, $103.1 \mathrm{~kg}$ of the initial product was pneumatically transported to the product bunker and then to the classifier feed bunker. Fresh feed from the remaining crushed fuel elements was added to the bed to make up for the loss in volume, and the burning operation was restarted as before. Fresh feed was again introduced to maintain a minimum of 10 wt \% of carbon in the bed as the fines were depleted by burning. After all of the crushed product (minus samples) had been added, the remaining carbon was combusted using induction heating to maintain temperature. After cooling, the final product was transported to the product bunker and the classifier feed bunker in two batches to avoid exceeding the capacity of the product bunker load cells. Materials were fed to the transport system at a rate of $0.5 \mathrm{~kg} / \mathrm{s}$ using a variableposition knifegate valve. The variable-speed blower was adjusted to the minimum speed which provided reliable transport. 
No problems occurred throughout the combustion of the product from the 20 crushed fuel elements, and peak carbon burn rates of over 900 $\mathrm{g} / \mathrm{min}$ were attained. This rate corresponds to the combustion of the equivalent of one-half of a crushed fuel element per hour.

Off-gas filter pressure drops were uniformly low $\left(<30\right.$ in $\mathrm{H}_{2} \mathrm{O}$ ) throughout the runs. This and other pertinent run parameters such as temperatures, pressures, and gas flows are shown in detail in Figs. 5-2 through $5-14$.

\subsubsection{Instrumentation}

Computer programs were developed for recording and processing pertinent data during the run. Twenty-four channels of data were scanned and recorded on a magnetic disc every $15 \mathrm{~s}$. In addition, the carbon burn rate and total carbon burned were calculated and displayed every $15 \mathrm{~s}$. This was the first run where the operators could automatically monitor the burn rate during operation. Other selected data including the time and gas concentrations as well as burn rate and total carbon burned were printed. The printout was used by operators to check the long-term trends and to give relief operators a quick summary of the previous shifts.

\subsubsection{Product}

The composition, particle breakage, weight, and other pertinent characteristics of the initial and final product, the plenum backflow material, and the fines heel are given in Table 5-5.

The advantages of the gravity fines recycle system over the pneumatic system used in the initial sequential operation were evidenced by the improvements in both operation and product. The failures that resulted in temporary shutdowns and a premature end to the combustion operations in the initial sequential test did not occur. This allowed combustion of 


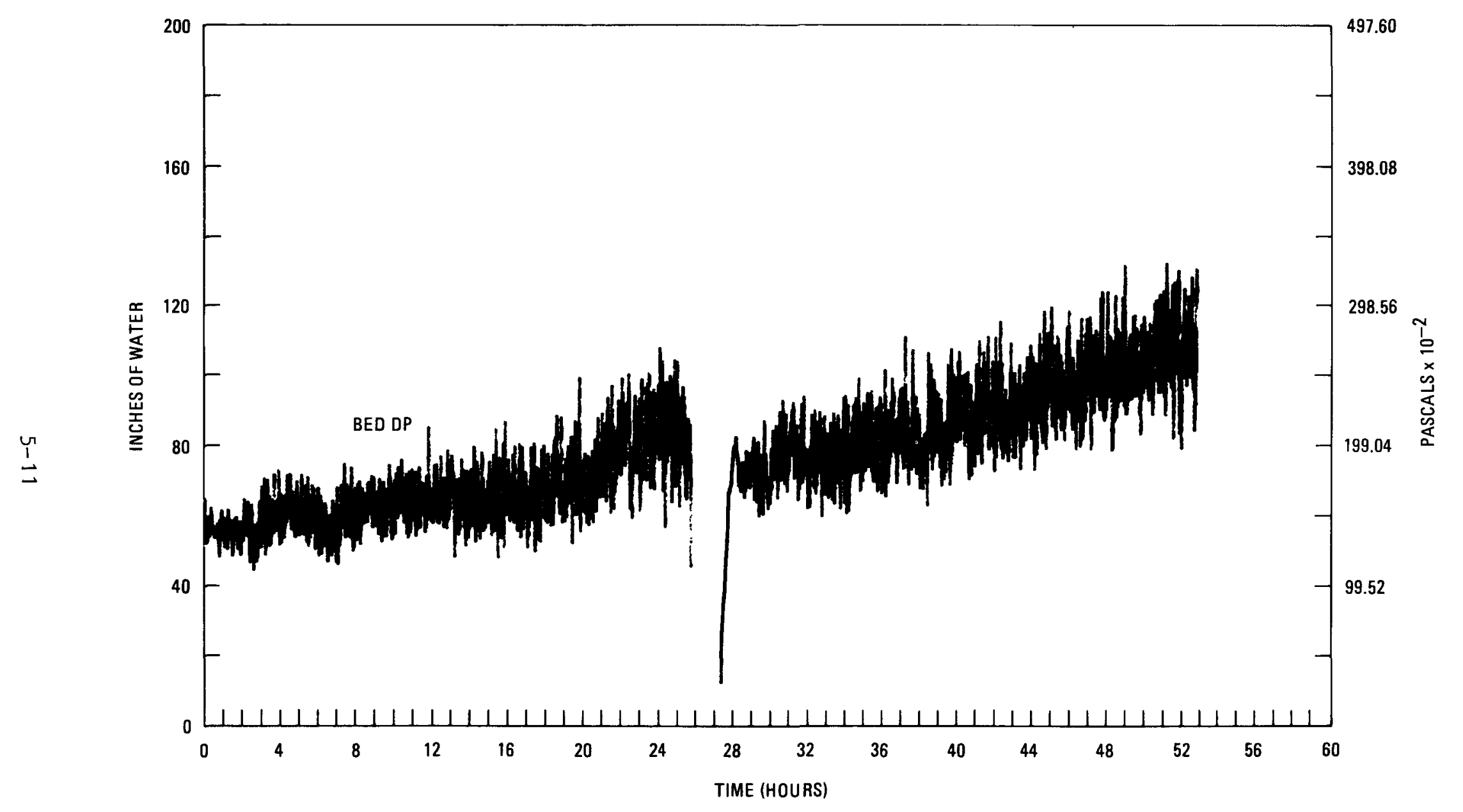

Fig. 5-2. Primary burner bed differential pressure (DP) 


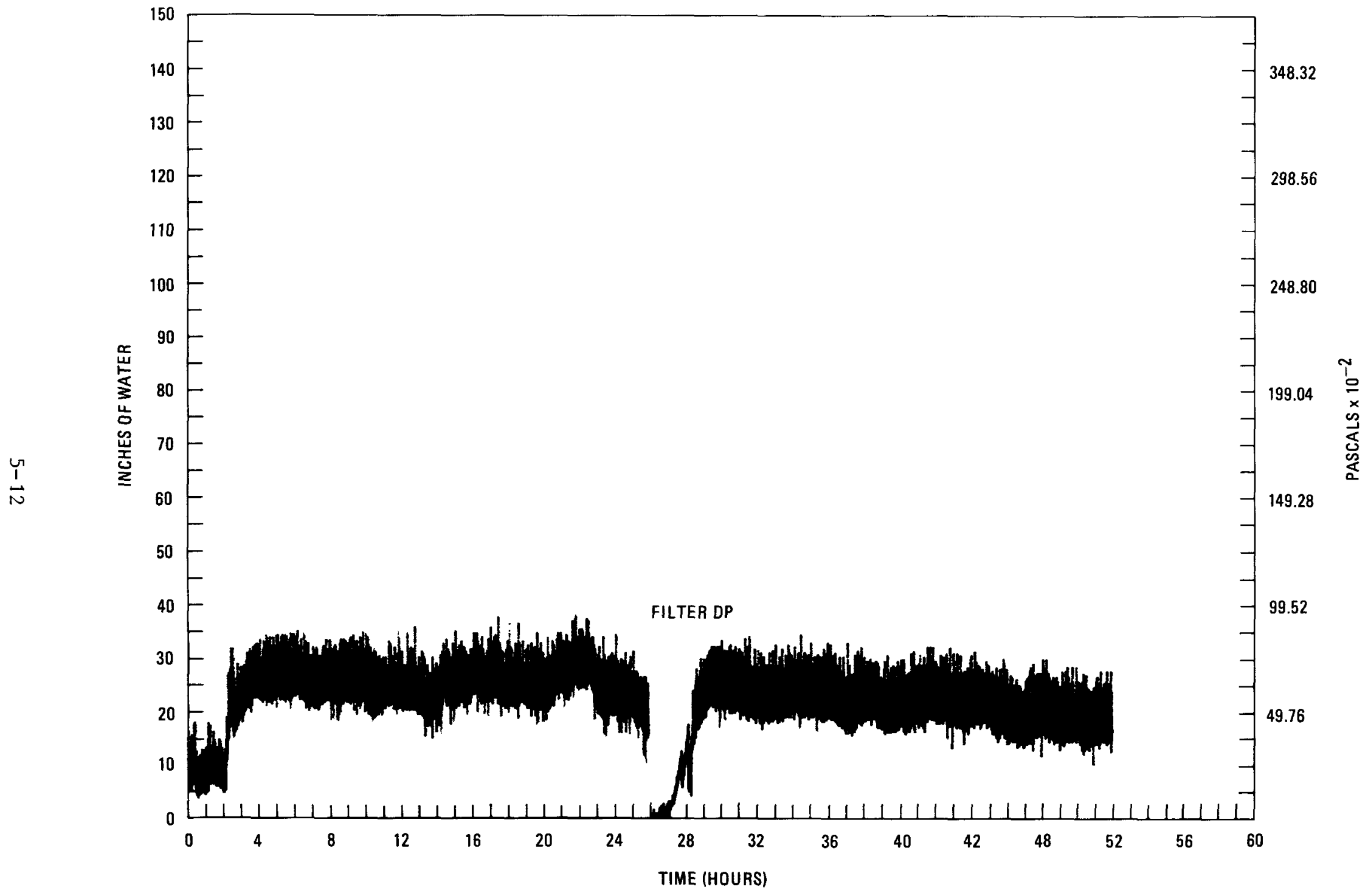

Fig. 5-3. Primary burner filter pressure 


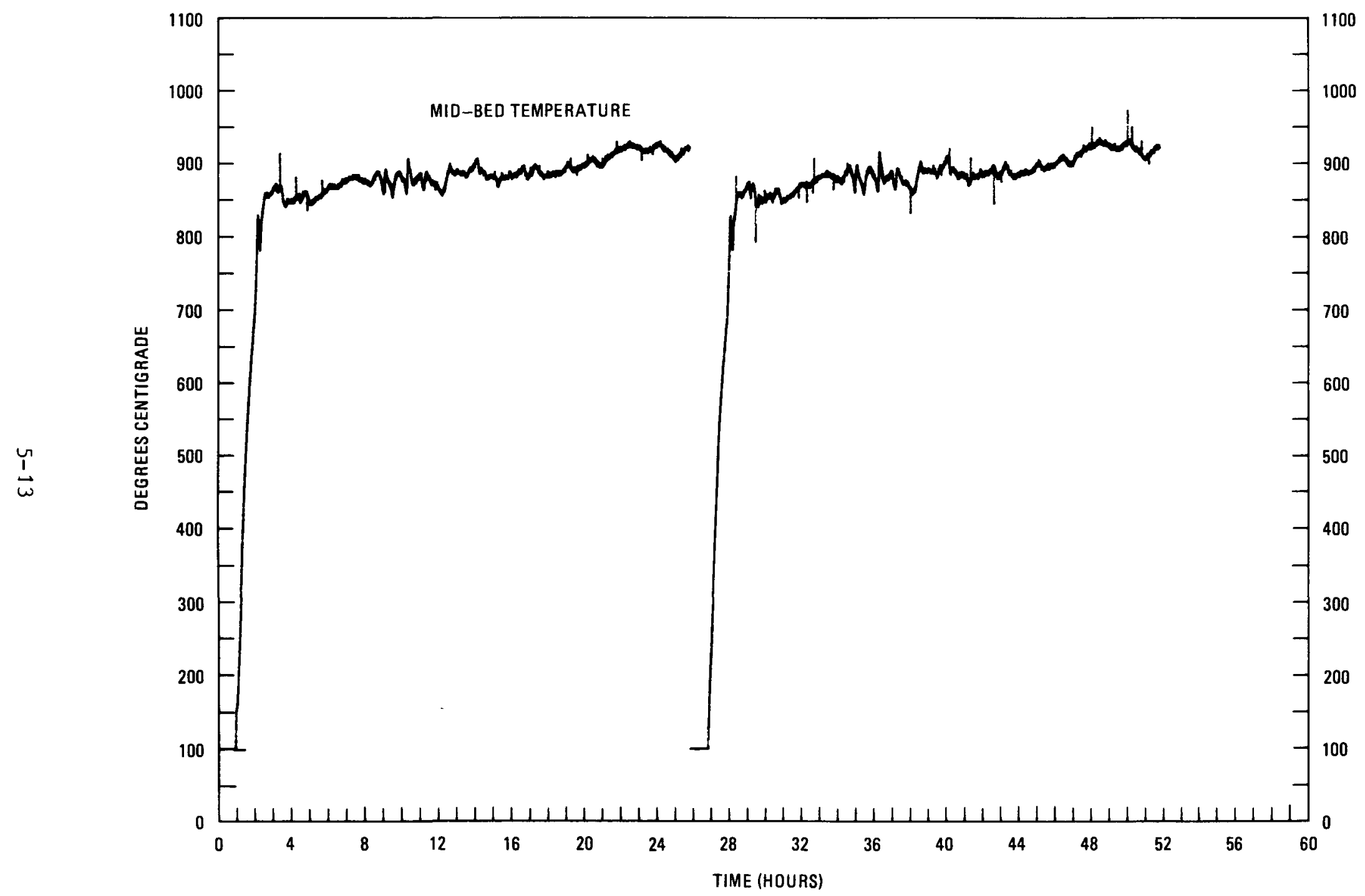

Fig. 5-4. Primary burner mid-bed temperature 


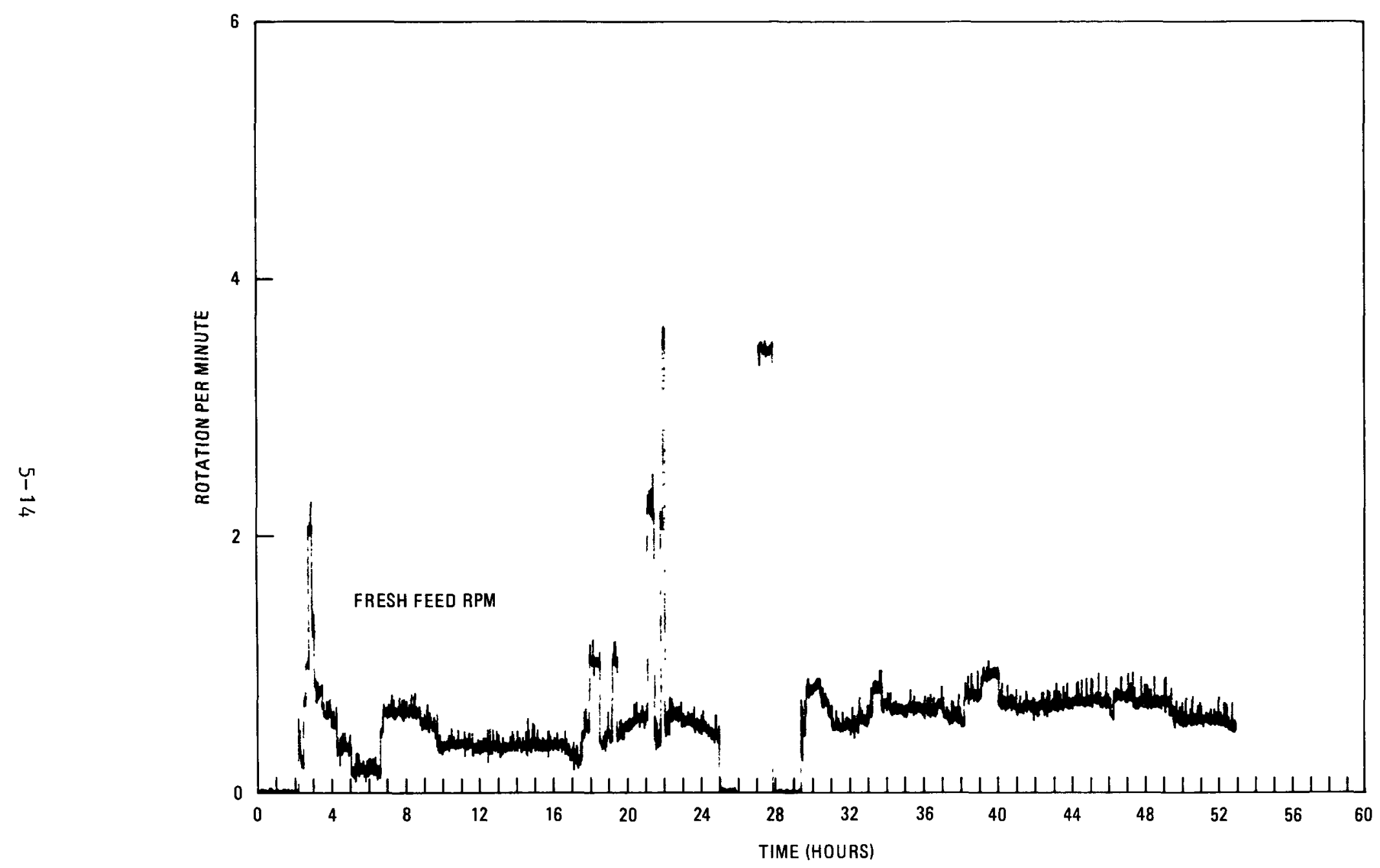

Fig. 5-5. Primary burner fresh feed rotary valve rpm 


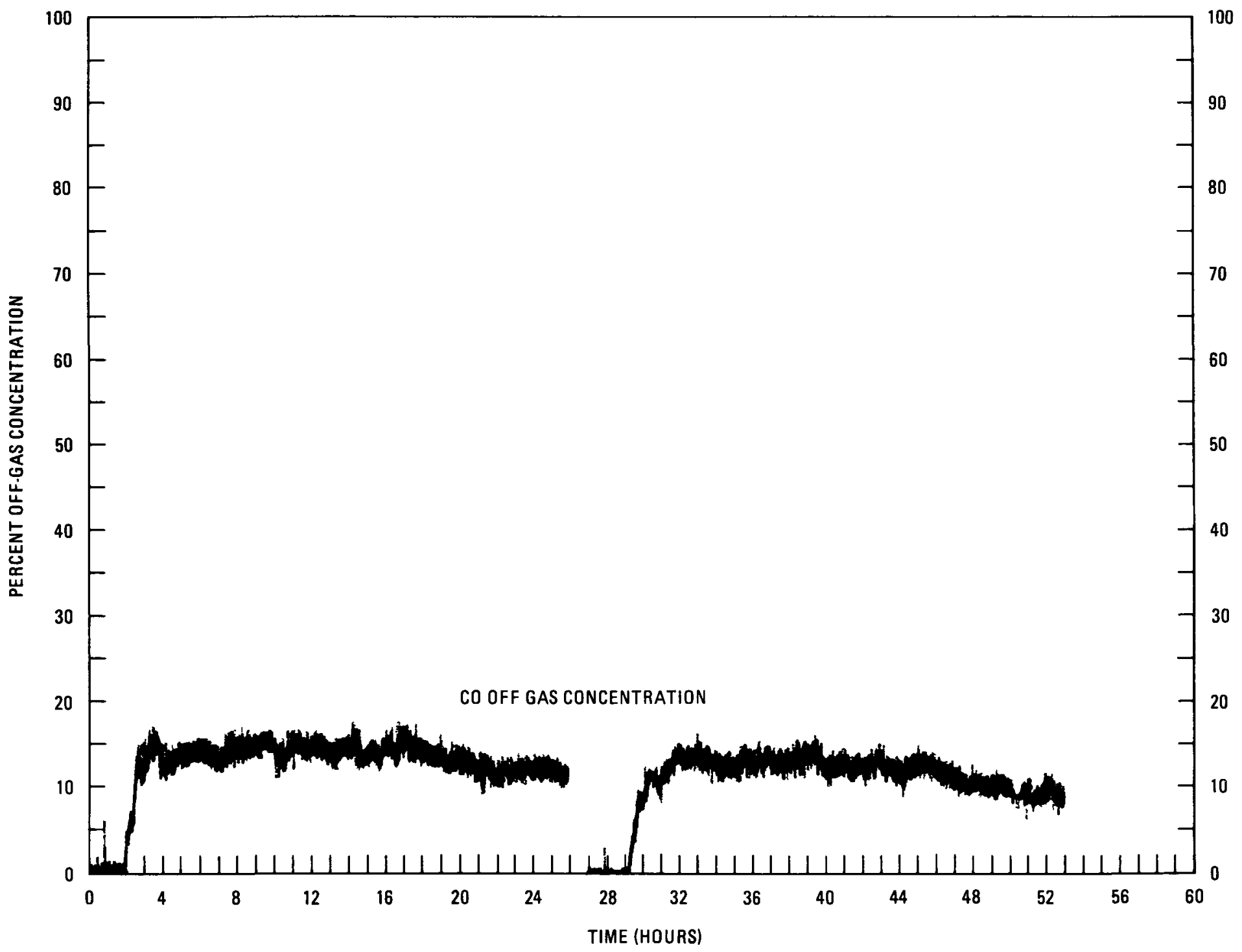

Fig. 5-6. Primary burner $C 0$ off-gas concentration 


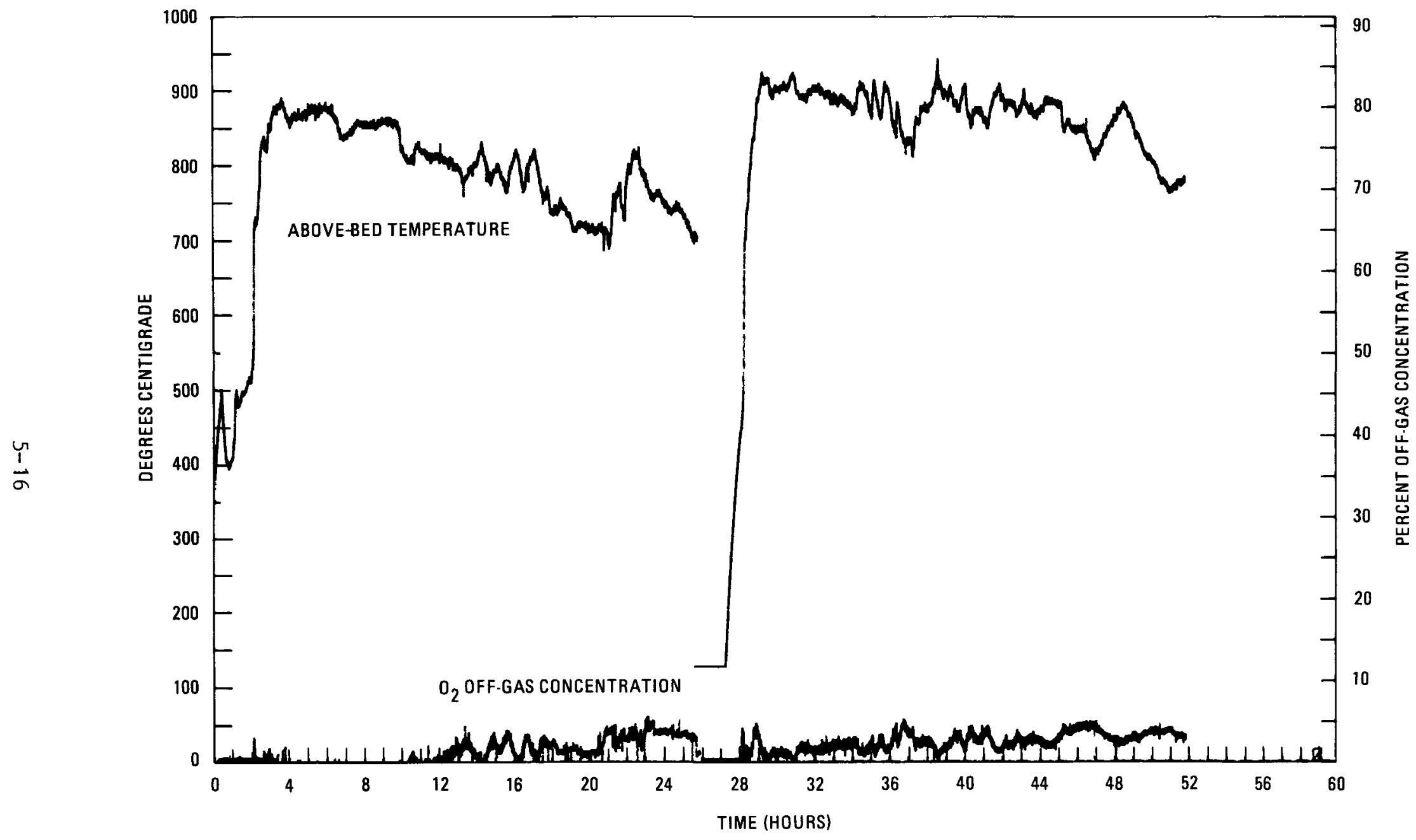

Fig. 5-7. Primary burner above-bed temperature and $\mathrm{O}_{2}$ off-gas concentration 


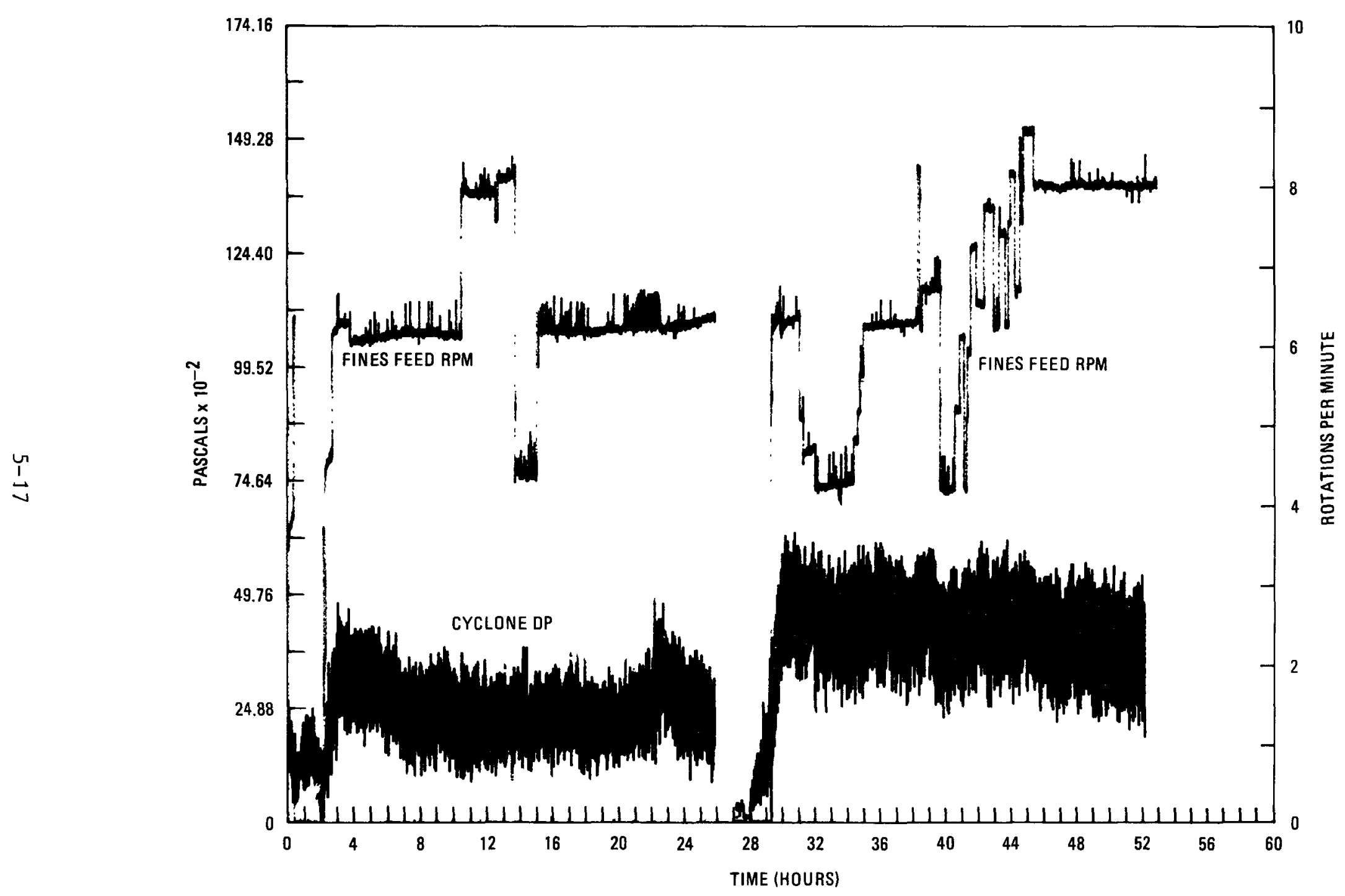

Fig. 5-8. Primary burner cyclone pressure 


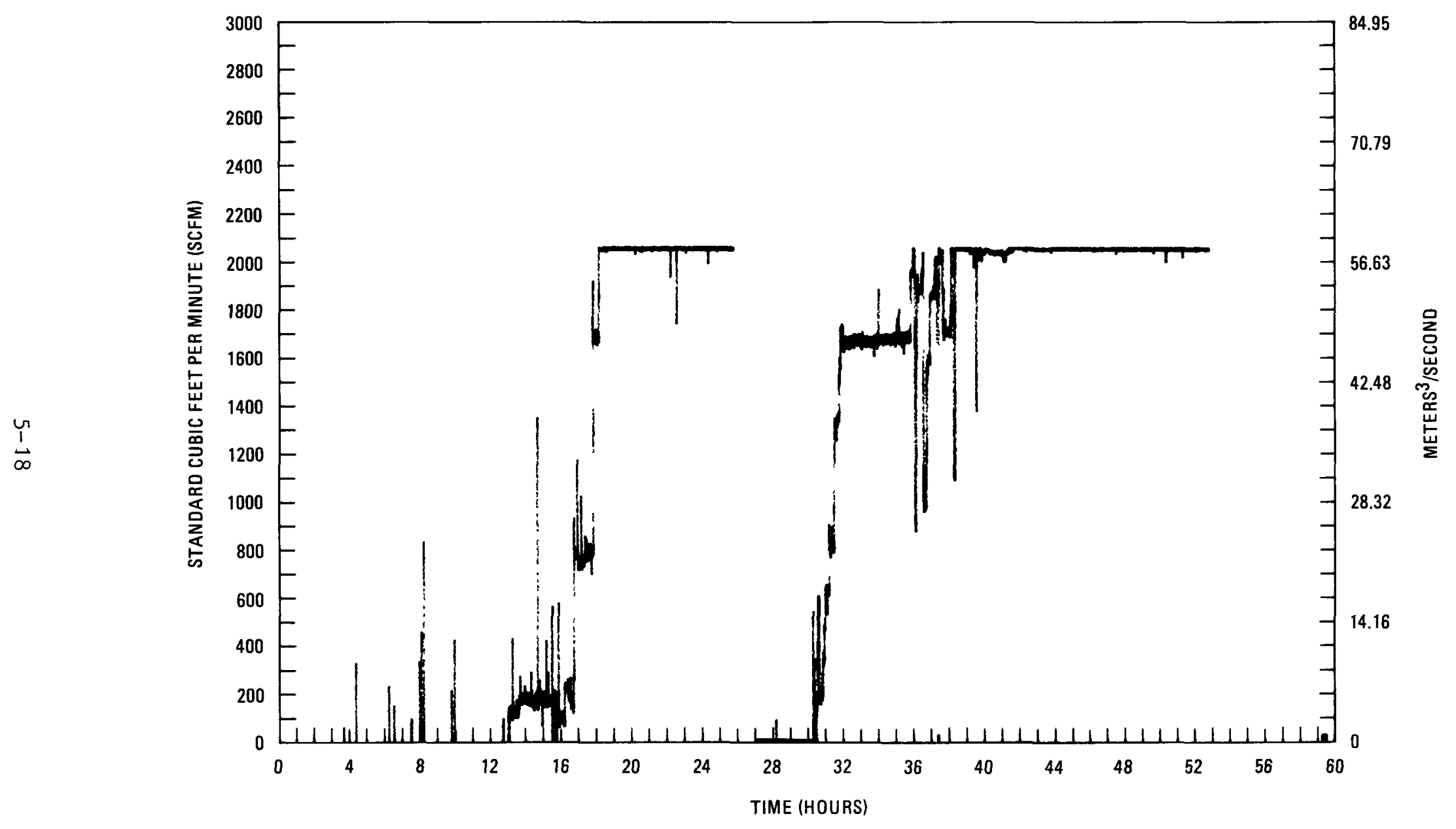

Fig. 5-9. Primary burner lower cooling air flow 


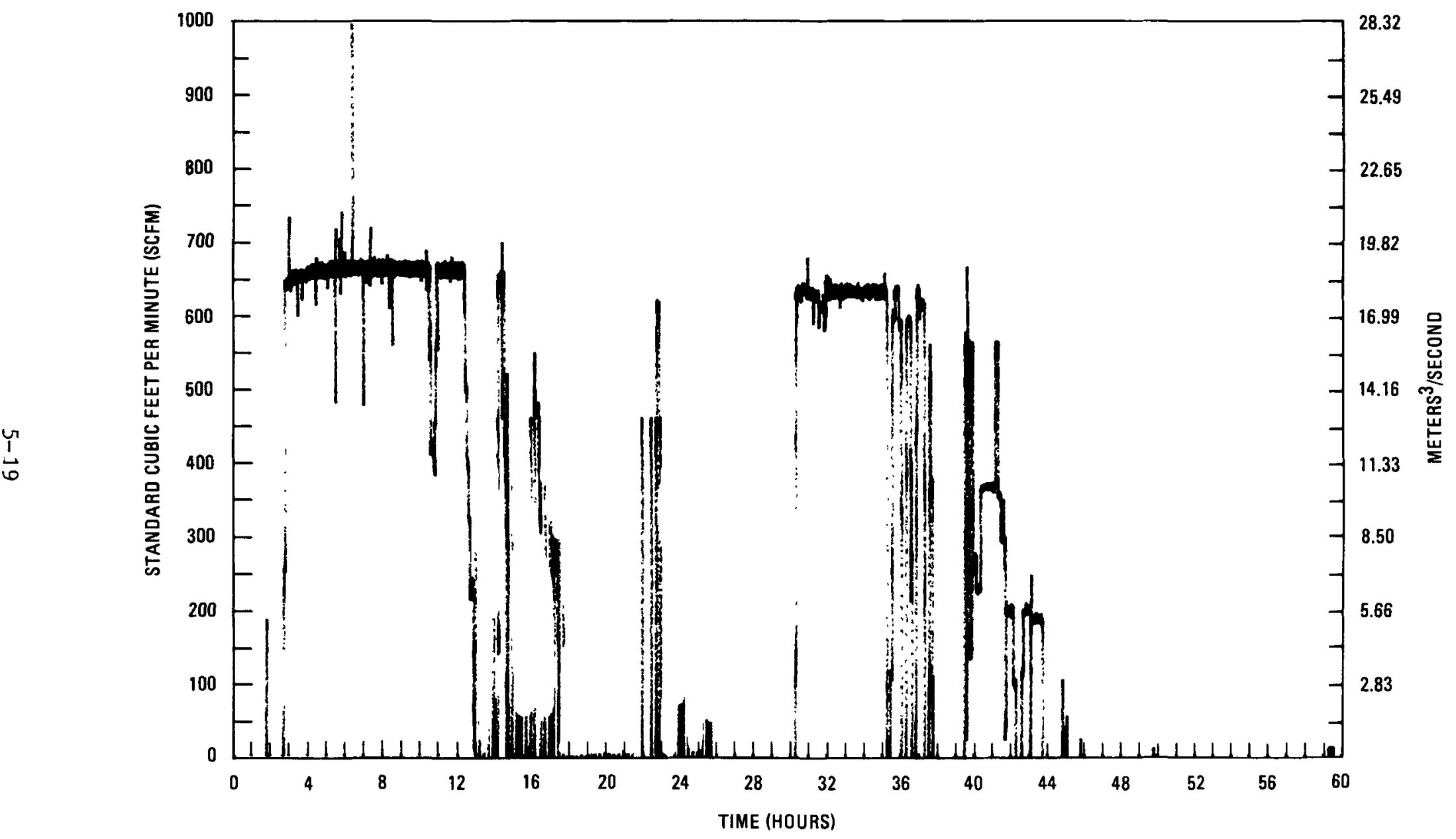

Fig. 5-10. Primary burner upper cooling air 


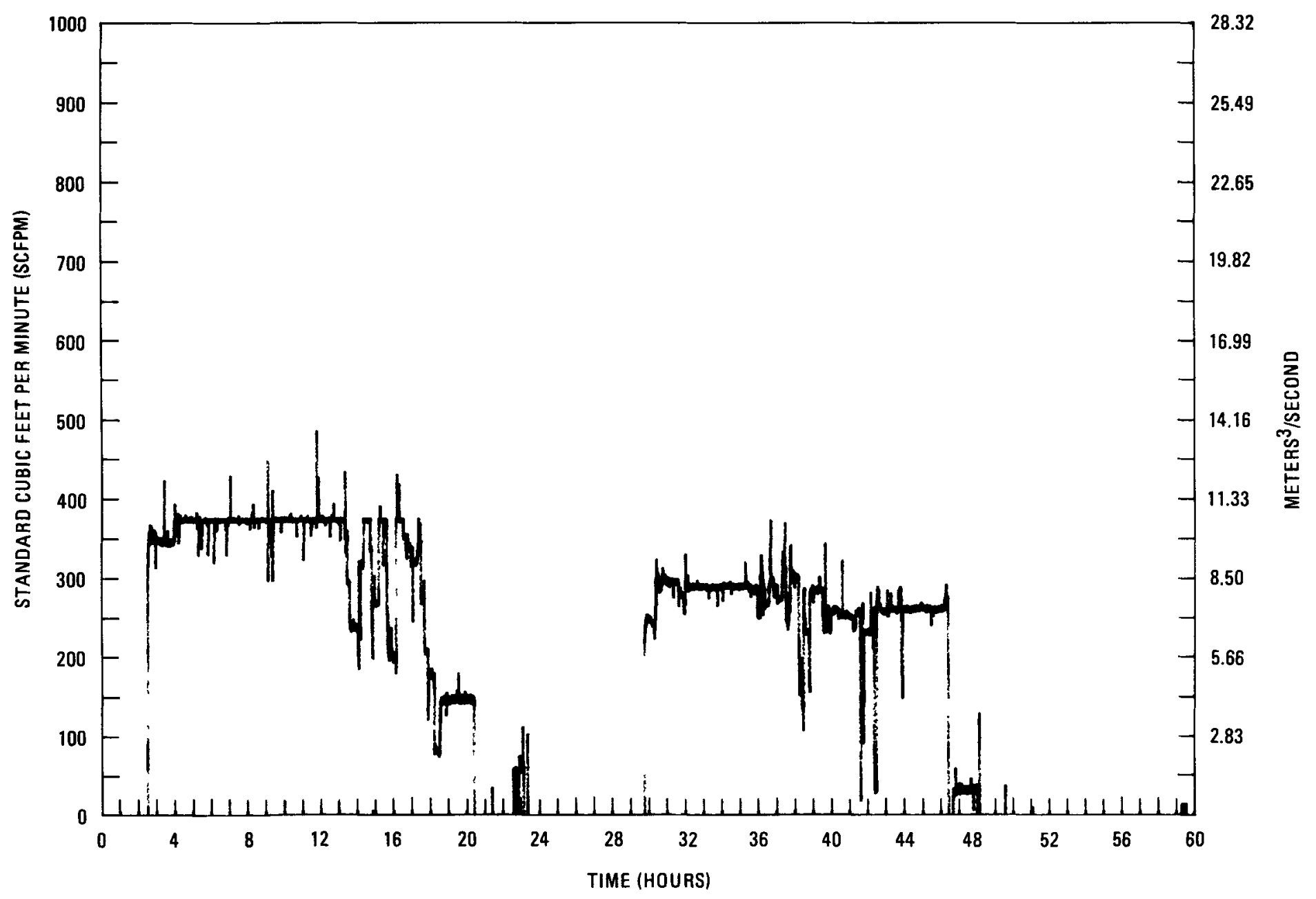

Fig. 5-11. Primary burner fines pipe cooling air 


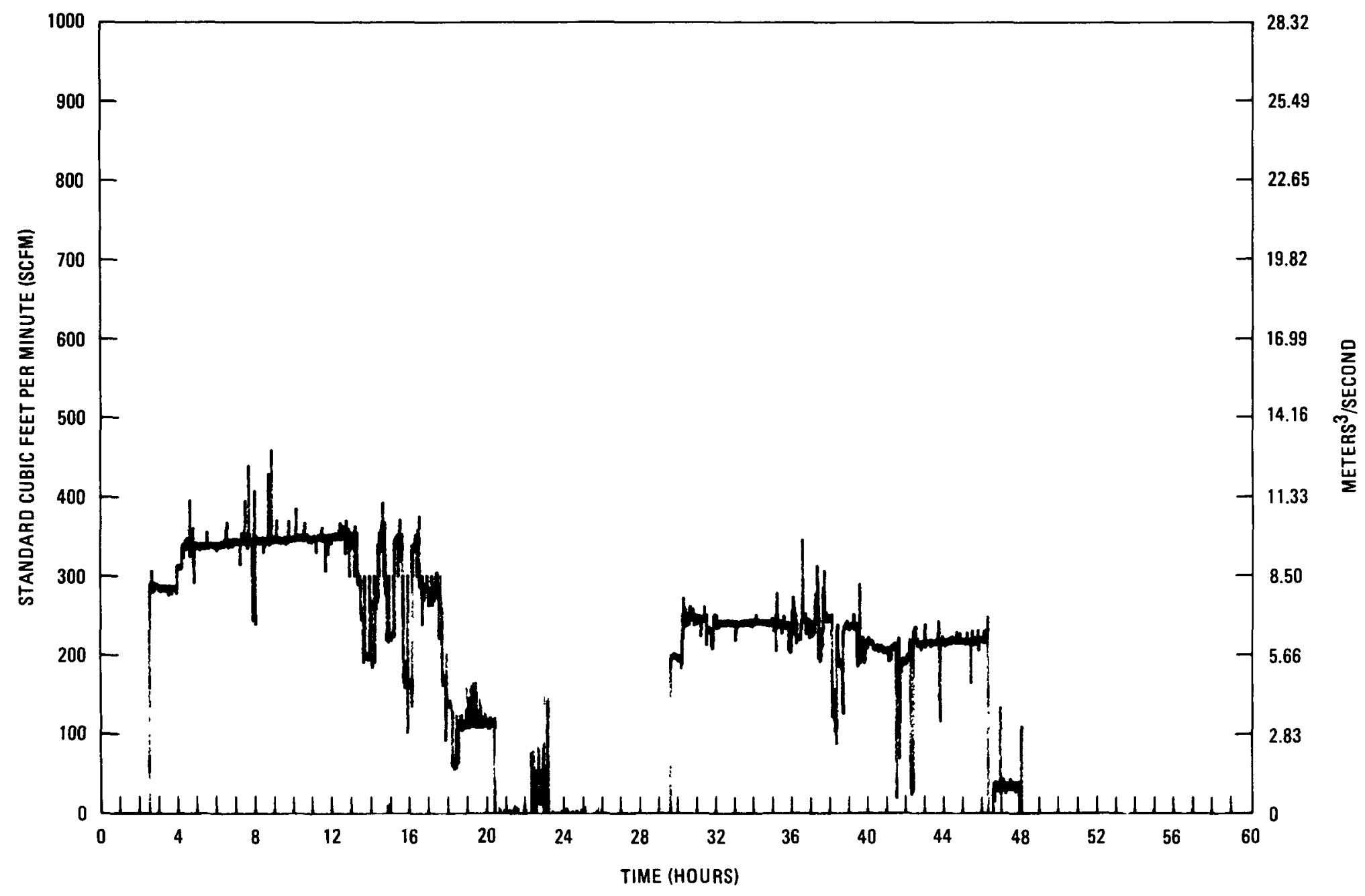

Fig. 5-12. Primary burner cyclone cooling air 


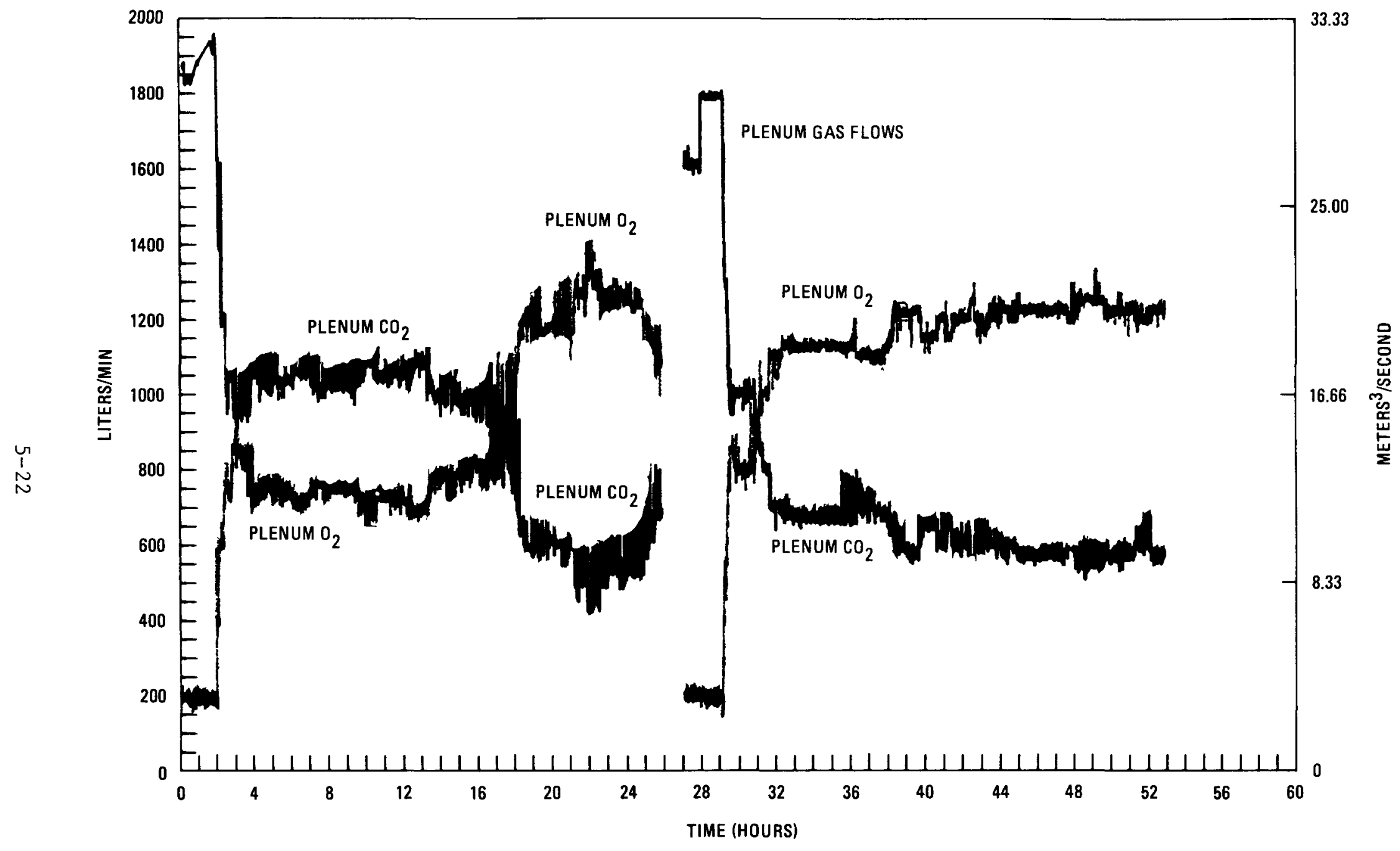

Fig. 5-13. Primary burner plenum gas flows 


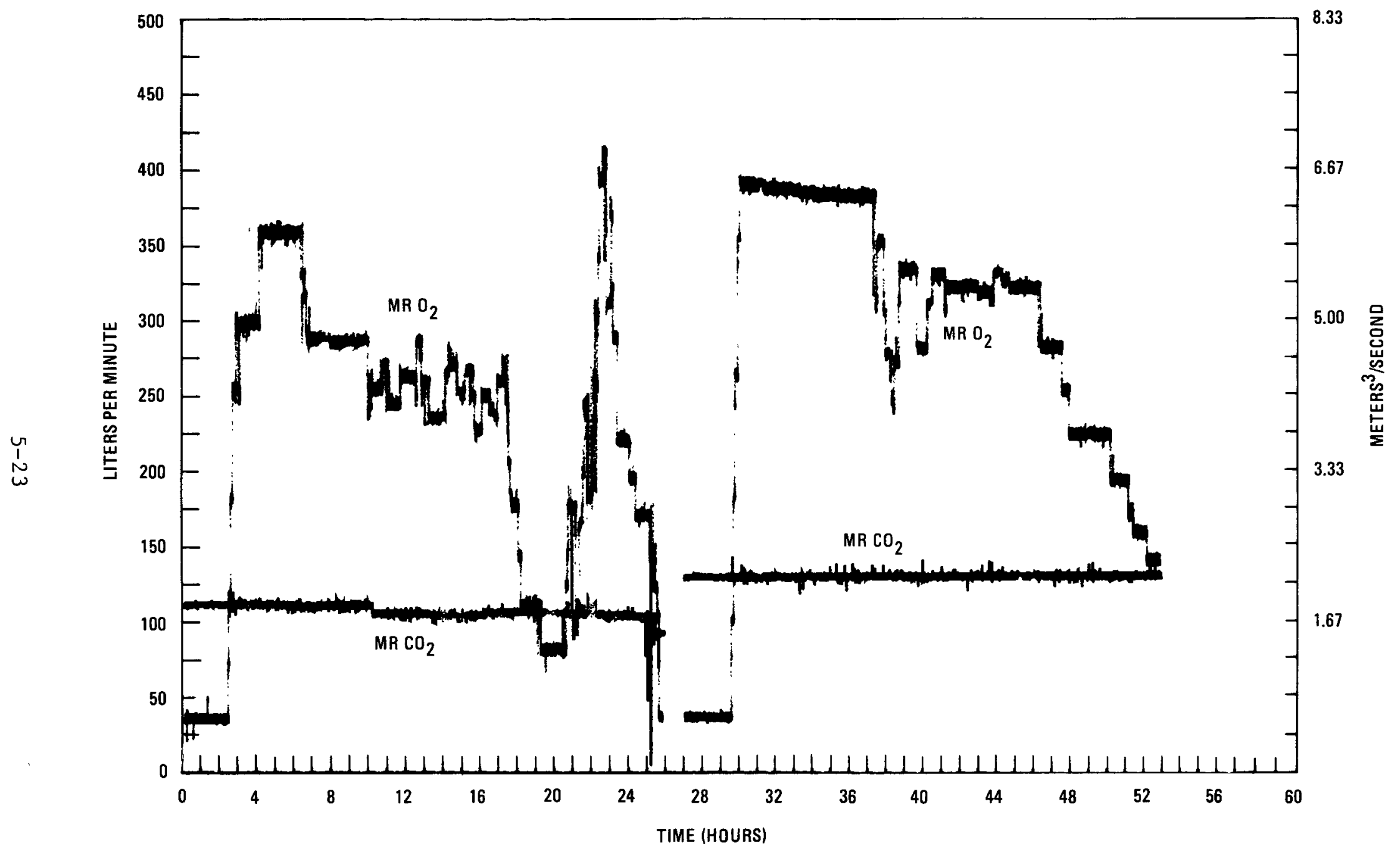

Fig. 5-14. Primary burner midreactor gas flows 
TABLE 5-5

PRIMARY BURNER PRODUCTS FOR PILOT PLANT SEQUENTIAL OPERATION

Total weight, $\mathrm{kg}$

BISO kernels, \%

TRISO particles, $\%$

Carbon, \%

$-850+425 \mu \mathrm{m}, \%$

Broken BISO, \%

Broken TRISO, \%

Total weight, $\mathrm{kg}$

Noncombustibles, kg

$\mathrm{SiC}, \%$

$\mathrm{U}_{3} \mathrm{O}_{8}, \%$

BISO particles, \%

TRISO particles, \%

$+250 \mu \mathrm{m}, \%$

$-250+63 \mu \mathrm{m}, \%$

$-63 \mu \mathrm{m}, \%$

Total Product

$\begin{array}{rrrrr}\begin{array}{rrr}\text { Initial } \\ \text { Product }\end{array} & & \begin{array}{c}\text { Final } \\ \text { Product }\end{array} & & \begin{array}{c}\text { Plenum } \\ \text { Backflow }\end{array} \\ 99.9 & & 270.9 & & 23.6 \\ 96.2 & & 21.7 & & 84.2 \\ 2.6 & & 77.5 & & 12.7 \\ 1.2 & & 0.8 & & 3.1 \\ 98.5 & & 98.0 & & 91.0 \\ 2.0 & & 0.3 & & 6.3 \\ 18.0 & & 13.0 & & 24.0\end{array}$

Fines Heel

0.520

0.094

75.0

7.0

18.0

0.1

0.7

8.0

91.3

$394.9 \mathrm{~kg}$ 
the 20 crushed fuel elements to completion and resulted in only $1.2 \mathrm{wt}$ $\%$ and 0.8 wt \% unburned carbon in the initial and final products, respectively. Overall particle breakage was also reduced due to the less violent nature of the gravity recycle system.

The modification to the gas distributor resulted in a reduction of plenum backflow material from $\sim 126 \mathrm{~kg}$ in the initial operation to $\sim 24 \mathrm{~kg}$ in the second sequential operation.

\subsection{PARTICLE CLASSIFICATION}

\subsubsection{Air Classification Operations}

Separation of the fissile and fertile fuel particles in the primary burner product was accomplished in three separate air classification runs. The first was the product removed after combustion of the first ten fuel elements. The second and third were the final product from the remaining combustion operation.

These materials were transported from the primary burner product bunker at a $15-\mathrm{m} / \mathrm{s}$ transport velocity and at a rate of $0.25 \mathrm{~kg} / \mathrm{s}$. The weight gains and losses of the primary burner product and classifier feed bunkers and the weights of the samples removed prior to the classifier bunker are given in Table 5-6. The differences in the burner and classifier results are attributable to errors introduced by the classifier crusher suspension system. A classifying gas velocity of $6.0 \mathrm{~m} / \mathrm{s}$ was used in all three runs. There were no equipment modifications to the air classification system between the initial and second sequential operations.

\subsubsection{Feed Rates}

Feed rates were obtained from the rate of weight loss from the feed bunker measured by the load cells. After the feed reached the 
TABLE 5-6

PRIMARY BURNER PRODUCT BUNKER AND CLASSIFIER FEED BUNKER WEIGHTS RECORDED DURING SEQUENTIAL OPERATION

\begin{tabular}{|c|c|c|c|c|}
\hline $\begin{array}{l}\text { Weight Gain } \\
\text { Primary Burner } \\
\text { Product Bunker } \\
\quad(\mathrm{kg}) \\
\end{array}$ & $\begin{array}{c}\text { Weight Loss } \\
\text { Primary Burner } \\
\text { Product Bunker } \\
(\mathrm{kg}) \\
\end{array}$ & $\begin{array}{c}\text { Sample Weight } \\
(\mathrm{kg})\end{array}$ & $\begin{array}{c}\text { Weight Gain } \\
\text { Classifier } \\
\text { Feed } \\
\end{array}$ & $\begin{array}{c}\text { Weight Loss } \\
\text { Classifier } \\
\text { Feed } \\
\end{array}$ \\
\hline 176.9 & $\begin{array}{l}103.1 \\
74.2^{(a)}\end{array}$ & $\begin{array}{c}\text { None taken } \\
0.40\end{array}$ & 99.8 & 99.8 \\
\hline $179.7^{(b)}$ & 179.3 & 1.71 & 177.0 & 175.3 \\
\hline 98.4 & 100.4 & 2.08 & 96.2 & 95.6 \\
\hline \multicolumn{5}{|l|}{ Totals } \\
\hline 455 & 457 & 4.19 & 373.0 & 370.7 \\
\hline-74.2 recycle & -74.2 recyc] & & & \\
\hline-4.2 samples & -4.2 sample & & & \\
\hline 376.6 & 378.6 & & & \\
\hline
\end{tabular}


level of the bellows on the bunker, it no longer affected the load cells. Therefore, to ensure cleanout, the classifier was operated for a few minutes after the readings showed no further weight loss.

The total time required for all three parts of the classification was $7 \mathrm{~h} 26 \mathrm{~min}$ at an overall average feed rate of $0.81 \mathrm{~kg} / \mathrm{min}$, not including the cleanout times. A summary of the feed rates is given in Table 5-7.

At the startup of Part I, the power to the vibratory feeder was increased in steps. At $70 \%$ power, the feed reached design level and this setting was used for the remainder of Part I and all of Part II. However, shortly after the start of Part III, the feed rate dropped and the power was raised to $100 \%$ to compensate. The drop in rate at $70 \%$ power was attributable to the segregation of particles in the primary burner. This produced feed which was predominately BISO kernels for Part I, Part II, and the initial portion of Part III. As the feed became richer in the lighter TRISO particles, the rate reduced. This reduction was substantiated by a simultaneous increase in the proportion of overheads (TRISO stream) indicated by the load cells on the product bunkers.

\subsubsection{Material Balances}

The total weights of the feed, underflow (BISO stream), and overheads (TRISO stream) were obtained from the load cell readouts taken before and after completion of each classification run with all equipment turned off to reduce vibration. After each run, the samples were removed and materials in the filter bunker were discharged after blowing back the filters. The samples and filter materials were weighed on a balance. Material balance product breakdowns, totals, and summary are given in Table 5-8.

The segregation of BISO and TRISO fuel particles is evident from the results listed in the table. In Parts $I$ and II, the overhead content 
TABLE 5-7

CLASSIFIER FEED RATES FROM THE PILOT PLANT SEQUENTIAL OPERATIONS

\begin{tabular}{|c|c|c|c|c|}
\hline \multirow[b]{2}{*}{ Run } & \multicolumn{2}{|c|}{ Time } & \multirow{2}{*}{$\begin{array}{l}\text { Feeder } \\
\text { Power } \\
\text { Setting } \\
\quad(\%)\end{array}$} & \multirow{2}{*}{$\begin{array}{l}\text { Average } \\
\text { Feed } \\
\text { Rate } \\
(\mathrm{kg} / \mathrm{min})\end{array}$} \\
\hline & (h) & (min) & & \\
\hline \multirow[t]{3}{*}{ Part I } & - & 4 & 20 & $<0.01$ \\
\hline & - & 5 & 50 & 0.04 \\
\hline & 2 & 6 & 70 & 0.75 \\
\hline Total & 2 & 15 & & 0.72 \\
\hline Part II & 3 & 29 & 70 & 0.82 \\
\hline \multirow[t]{3}{*}{ Part III } & - & 4 & 70 & 0.79 \\
\hline & - & 11 & 70 & 0.52 \\
\hline & 1 & 27 & 100 & 0.96 \\
\hline Total & 1 & 42 & & 0.91 \\
\hline Overa11 & 7 & 26 & & 0.81 \\
\hline
\end{tabular}


TABLE 5-8

AIR CLASSIFICATION MATERIAL BALANCE

Summary

Total

\begin{tabular}{|c|c|c|c|c|}
\hline \multirow[b]{2}{*}{ Run } & \multirow{2}{*}{$\begin{array}{l}\text { Feed } \\
(\mathrm{kg})\end{array}$} & \multirow{2}{*}{$\begin{array}{l}\text { Recovery } \\
\text { (kg) }\end{array}$} & \multicolumn{2}{|c|}{ MUF } \\
\hline & & & $(\mathrm{kg})$ & $(\%)$ \\
\hline & 99.88 & 103.84 & 3.96 & 3.96 \\
\hline II & 175.31 & 180.96 & 5.65 & 3.22 \\
\hline III & 95.59 & 98.99 & 3.40 & 3.56 \\
\hline & 370.78 & 383.79 & 13.01 & 3.51 \\
\hline
\end{tabular}

Totals

\begin{tabular}{|c|c|c|c|c|c|}
\hline \multicolumn{2}{|c|}{$\begin{array}{l}\text { Overheads } \\
\text { (Fissile Stream) }\end{array}$} & \multicolumn{2}{|c|}{ Underflows } & \multicolumn{2}{|c|}{ Total } \\
\hline$(\mathrm{kg})$ & $(\%)$ & $(\mathrm{kg})$ & $(\%)$ & $(\mathrm{kg})$ & $(\%)$ \\
\hline 4.24 & 4.0 & 99.60 & 95 & 103.84 & 100 \\
\hline 7.44 & 4.11 & 173.52 & 95.89 & 180.96 & 100 \\
\hline 76.85 & 77.63 & 22.14 & 22.37 & 98.99 & 100 \\
\hline 88.53 & 23.07 & 295.26 & 76.93 & 383.79 & 100 \\
\hline
\end{tabular}

Product Breakdown

Underflows

Product

Sample

Total

\begin{tabular}{|c|c|c|c|c|c|c|}
\hline Run & $(\mathrm{kg})$ & $(\%)$ & $(\mathrm{kg})$ & $(\%)$ & $(\mathrm{kg})$ & $(\%)$ \\
\hline Part I & 93.48 & 93.86 & 6.12 & 6.14 & 99.60 & 100 \\
\hline Part II & 167.32 & 96.43 & 6.20 & 3.57 & 173.52 & 100 \\
\hline Part III & 21.60 & 97.56 & 0.54 & 2.44 & 22.14 & 100 \\
\hline Total & 282.40 & 95.64 & 12.86 & 4.36 & 295.26 & 100 \\
\hline
\end{tabular}

Overheads

Product

Filter

Sample

Total

\begin{tabular}{|c|c|c|c|c|c|c|c|c|}
\hline Run & $(\mathrm{kg})$ & $(\%)$ & $(\mathrm{kg})$ & $(\%)$ & $(\mathrm{kg})$ & $(\%)$ & $(\mathrm{kg})$ & $(\%)$ \\
\hline Part I & 2.35 & 55.42 & 1.84 & 43.40 & 0.05 & 1.18 & 4.24 & 100 \\
\hline Part II & 4.71 & 63.31 & 2.67 & 35.89 & 0.06 & 0.81 & 7.44 & 100 \\
\hline Part III & 65.31 & 84.98 & 10.72 & 13.95 & 0.82 & 1.07 & 76.85 & 100 \\
\hline Total & 72.37 & 81.75 & $\overline{15.23}$ & $\overline{17.20}$ & 0.93 & $\overline{1.05}$ & $\overline{88.53}$ & 100 \\
\hline
\end{tabular}


was only $\sim 4 \%$ of the product, while in Part III it was $278 \%$. The consistent positive MUF of over $3 \%$ was due to errors introduced by the feed bunker suspension system. A newly installed product removal system was used to transfer the underflow and overflow products from the bunkers to a bunker for discharge from the system. The weight losses in the respective bunkers and the actual weights of product obtained on a scale are shown in Table 5-9. The load cell readings agreed with the actual weights within $1 \%$ except the weight loss reading for the TRISO bunker, which was over $4 \%$ in error.

\subsubsection{Sampling}

Two types of continuous in-line automatic samplers were used to obtain samples concurrently with classification. The overheads (fissile streams) were sampled with a gravity feed sampler designed at GA. The underflows (fertile streams) were sampled with a Vezin laboratory sampler. Each of the overhead, underflow, and filter material samples was analyzed for size distribution, carbon content, and broken fuel particles.

The materials discharged from the filter bunker were split-sampled in a 12-to-1 riffle splitter. The larger underflow samples were also split to obtain a more reasonable size sample for analysis.

The weight of samples obtained is shown in the product breakdown of Table 5-8. The Vezin sampler took a reasonably sized sample of about $1 \%$ of the total underflow. To reduce the quantity of samples taken by the gravity sampler, one of the sample tubes was sealed off prior to Part III. Upon removal to accomplish the operation, it was discovered that a fragment of graphite was blocking one of the tubes. This apparently occurred during Part II and resulted in a smaller sample from that of Part I. The deliberate blocking of the tube reduced the sample size from $6.1 \%$ in Part $I$ to $2.4 \%$ in Part III. 
TABLE 5-9

CLASSIFIER PRODUCT BUNKER AND ACTUAL PRODUCT

WEIGHTS RECORDED DURING SEQUENTIAL OPERATION

\begin{tabular}{|c|c|c|c|c|c|}
\hline $\begin{array}{c}\text { Gain TRISO } \\
\text { Bunker } \\
\text { (kg) }\end{array}$ & $\begin{array}{l}\text { Loss TRISO } \\
\text { Bunker } \\
(\mathrm{kg})\end{array}$ & $\begin{array}{c}\text { Actual } \\
\text { Weight TRISO } \\
\text { Product Removed } \\
(\mathrm{kg})\end{array}$ & $\begin{array}{c}\text { Gain BISO } \\
\text { Bunker } \\
(\mathrm{kg})\end{array}$ & $\begin{array}{c}\text { Loss BISO } \\
\text { Bunker } \\
(\mathrm{kg})\end{array}$ & $\begin{array}{c}\text { Actual } \\
\text { Weight BISO } \\
\text { Product Removed } \\
(\mathrm{kg})\end{array}$ \\
\hline 2.4 & 2.0 & 2.5 & 93.5 & 92.5 & 92.6 \\
\hline 4.7 & & & 167.3 & 167.8 & \\
\hline \multirow[t]{2}{*}{65.3} & $45.6^{(a)}$ & & 21.6 & 20.0 & 187.4 \\
\hline & 23.8 & 24.7 & & & \\
\hline
\end{tabular}

Totals

72.4

69.4

$\begin{array}{r}27.2 \\ +45.6^{(a)} \\ \hline 72.8\end{array}$

$282.4 \quad 280.3$

279.9

\footnotetext{
(a) Transferred to secondary burner feed.
} 


\subsubsection{Size Distribution}

The results of the screen analyses are summarized in Table 5-10. The totals for each run and the overall classifier product size distributions were calculated from the data obtained from the individual screen analyses and material balances.

As a result of normal segregation, the quantity of fines was expected to be greater in the last material removed from the burner. This was substantiated by the size distribution results. Parts $I$ and II each contained less than $3 \%$ product smaller than $425 \mu \mathrm{m}$ while Part III contained over $6 \%$. Also, as expected, the overheads contained more fines than the underflows and the largest percentage of fines was in the filter materials. However, a relative inefficiency of the cyclone was indicated by the quantity of product larger than $425 \mu \mathrm{m}$ in the filter materials.

The low overall percentage of $>850-\mu \mathrm{m}$ product indicated that few agglomerated particles or large fragments of graphite were present in the burner product. The small overall percentage of $<425-\mu \mathrm{m}$ product indicated that particle breakage may not be excessive.

\subsubsection{Carbon Content}

The results of the burnable carbon analyses are summarized in Table 5-11. The kilograms of carbon, the totals for each run, and the overall classifier product carbon content were calculated from the data obtained in the individual analyses and material balances.

The total burnable carbon in all of the classifier product was calculated to be $21.6 \%$. Since the carbon content is unchanged by classification, it is also representative of the carbon in the burner product, plus any burnable carbon coatings subsequently exposed by TRISO particle breakage during pneumatic transport and classification. 
TABLE $5-10$

SIZE DISTRIBUTIONS OF CLASSIFIED PRODUCTS

FROM THE PILOT PLANT SEQUENTIAL OPERATIONS

Weight Percent - Mesh Size in Microns

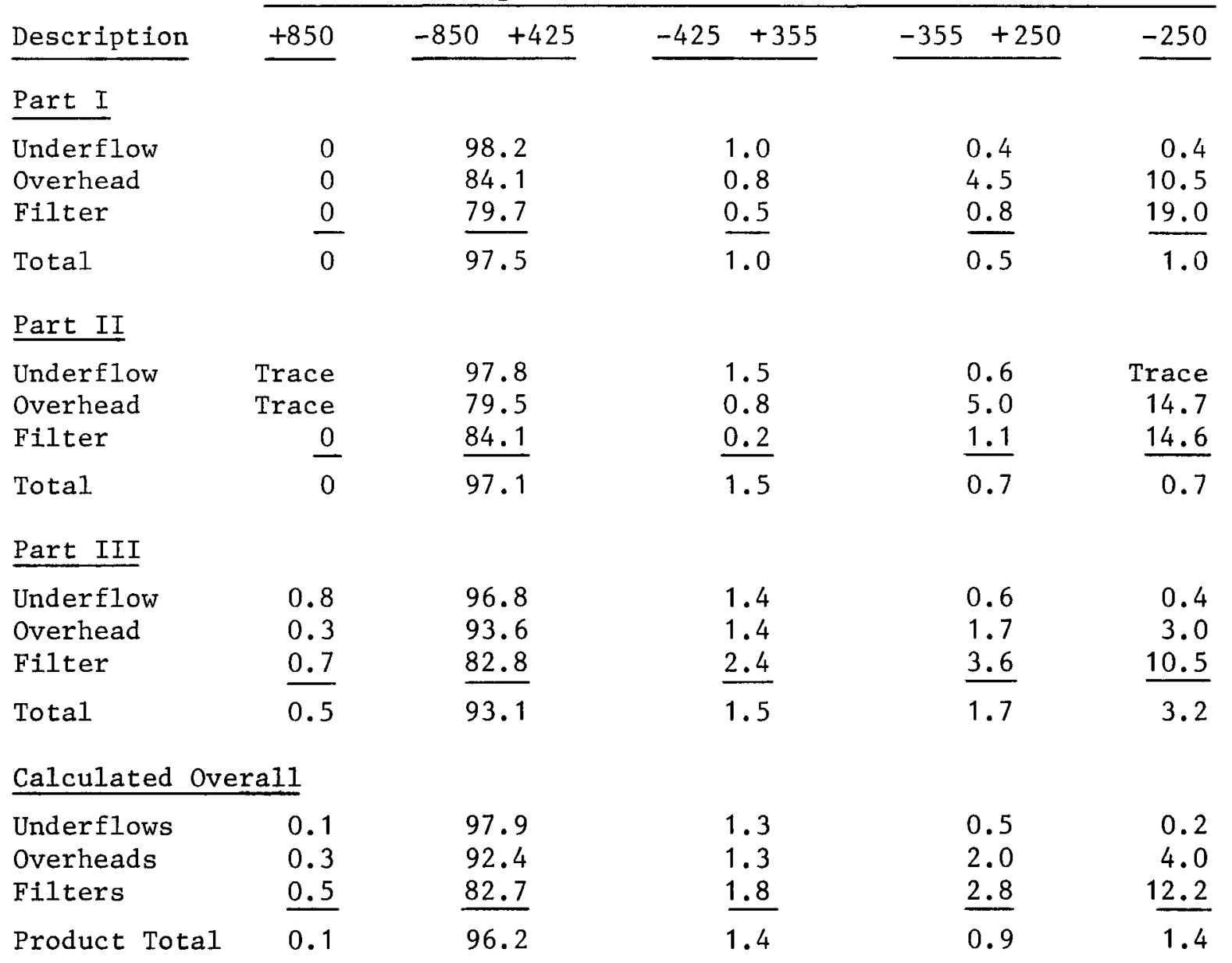


TABLE 5-11

CARBON CONTENT OF CLASSIFIED PRODUCTS

FROM THE PILOT PLANT SEQUENTIAL OPERATIONS

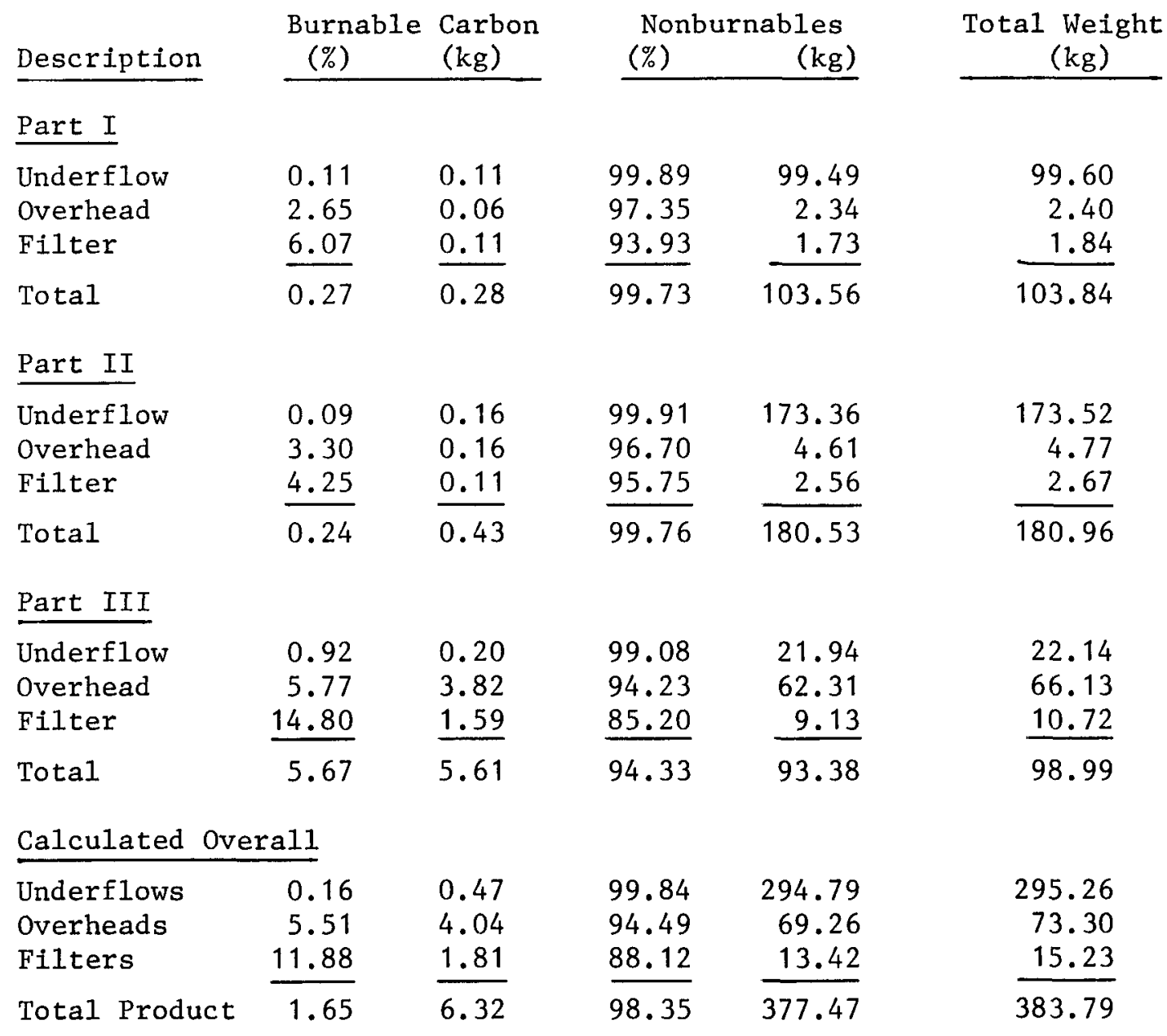


After primary burning, the residual carbon was expected to be present mainly as fines and, as a result of segregation, present mainly in the last material removed from the burner. This was substantiated by the carbon analyses. The overheads and filter materials contained a total of $\sim 5.8 \mathrm{~kg}$ of carbon and the underflows contained only $\sim 0.5 \mathrm{~kg}$. The percent carbon was almost 35 times greater in the overheads than in the underflows, and 74 times greater in the filter materials than in the underflows. The products from Part III contained $25.6 \mathrm{~kg}$ of carbon while the products from Parts I and II combined contained only $\sim 0.7 \mathrm{~kg}$.

\subsubsection{Particle Breakage}

The results of the particle breakage analyses are summarized in Table 5-12. The totals for each run and the overall classifier product broken particle content were calculated from the data obtained in the individual analyses and material balances.

The overall particle breakage was calculated to be $3.19 \%$ of the fertile and $22.82 \%$ of the fissile particles. Of the fertile particles found in the fissile streams (overheads and filter products), $68.22 \%$ and $40.26 \%$, respectively, were broken while only $1.98 \%$ of the fertile particles were broken in the fertile streams. A higher percentage of broken particles is also shown for fissile particles in the fertile stream than for fissile particles in the fissile stream. These results clearly show the tendency for broken particles to result in crossover.

\subsubsection{Heavy Metal Distribution}

The uranium and thorium results from the analyses for broken fuel particles were also used to calculate the heavy metal content and distribution in the classifier products. The results of these calculations are summarized in Table 5-13. 
TABLE 5-12

BROKEN FUEL PARTICLE CONTENT OF CLASSIFIED

PRODUCTS FROM THE PILOT PLANT SEQUENTIAL OPERATIONS

\begin{tabular}{llc} 
& Broken & Broken \\
Fertile & Fissile \\
Description & $(\%)$ & $(\%)$ \\
\hline
\end{tabular}

$\underline{\text { Part I }}$

Underflow

0.50

86.71

67.49

19.58

Filter

34.98

18.11

Total

0.81

48.94

Part II

Underflow

3.40

82.29

Overhead

50.33

14.12

Filter

66.94

$\frac{24.03}{37.07}$

Tota1

3.46

37.07

Part III

Underflow

2.75

74.19

Overhead

80.88

10.97

Filter

65.86

66.50

Tota1

10.88

18.67

Calculated Overall

$\begin{array}{lrr}\text { Underflows } & 1.98 & 82.11 \\ \text { Overheads } & 68.22 & 14.02 \\ \text { Filters } & 40.26 & 35.73 \\ \text { Product Total } & 3.19 & 22.82\end{array}$


TABLE $5-13$

HEAVY METAL CONTENT AND DISTRIBUTION IN THE CLASSIFIED

PRODUCTS FROM THE PILOT PLANT SEQUENTIAL OPERATIONS

\begin{tabular}{|c|c|c|c|c|c|c|c|}
\hline \multirow[b]{3}{*}{ Description } & \multicolumn{5}{|c|}{ Heavy Meta1 Content } & \multicolumn{2}{|c|}{$\begin{array}{l}\text { Heavy Metal } \\
\text { Distribution }\end{array}$} \\
\hline & \multicolumn{2}{|c|}{ Thorium } & \multicolumn{2}{|c|}{ Uranium } & \multirow{2}{*}{$\begin{array}{r}\text { Total } \\
(\mathrm{kg})\end{array}$} & \multirow{2}{*}{$\begin{array}{c}\text { Thorium } \\
(\%)\end{array}$} & \multirow{2}{*}{$\begin{array}{c}\text { Uranium } \\
(\%)\end{array}$} \\
\hline & $(\mathrm{kg})$ & $(\%)$ & $(\mathrm{kg})$ & $(\%)$ & & & \\
\hline \multicolumn{8}{|l|}{ Part I } \\
\hline Underflow & 87.30 & 87.65 & 0.52 & 0.52 & 87.82 & 99.51 & 42.97 \\
\hline Overhead & 0.38 & 16.03 & 0.37 & 15.34 & 0.75 & 0.43 & 30.58 \\
\hline Filter & 0.05 & 2.90 & 0.32 & 17.20 & 17.37 & 0.06 & 26.45 \\
\hline Total & 87.73 & 84.49 & 1.21 & 1.16 & 88.94 & 100.00 & 100.00 \\
\hline \multicolumn{8}{|l|}{ Part II } \\
\hline Underflow & 153.28 & 88.33 & 0.54 & 0.31 & 153.82 & 99.89 & 29.19 \\
\hline Overhead & 0.13 & 2.80 & 0.85 & 17.78 & 0.98 & 0.08 & 45.95 \\
\hline Filter & 0.05 & 1.83 & 0.46 & 17.31 & 0.51 & 0.03 & 24.86 \\
\hline Total & 153.46 & 84.80 & 1.85 & 1.03 & 155.31 & 100.00 & 100.00 \\
\hline \multicolumn{8}{|l|}{ Part III } \\
\hline Underflow & 19.36 & 87.43 & 0.08 & 0.34 & 19.44 & 88.97 & 0.57 \\
\hline Overhead & 2.27 & 3.43 & 11.89 & 17.99 & 14.16 & 10.43 & 85.05 \\
\hline Filter & 0.13 & 1.23 & 2.01 & 18.79 & 2.14 & 0.60 & 14.38 \\
\hline Total & 21.76 & 21.98 & 13.98 & 14.13 & 35.74 & 100.00 & 100.00 \\
\hline \multicolumn{8}{|c|}{ Calculated Overall } \\
\hline Underflows & 259.93 & 88.04 & 1.15 & 0.39 & 261.08 & 98.85 & 6.74 \\
\hline Overheads & 2.79 & 3.80 & 13.11 & 17.89 & 15.90 & 1.06 & 76.89 \\
\hline Filters & 0.23 & 1.54 & 2.79 & 18.34 & 3.02 & 0.09 & 16.37 \\
\hline Product Total & 262.95 & 68.52 & 17.05 & 4.44 & 280.00 & 100.00 & 100.00 \\
\hline
\end{tabular}


Overall thorium recovery was $98.85 \%$ in the fertile streams (underflows) and $1.15 \%$ in the fissile streams (overflows and filter materials). In both Parts I and II, over $99.5 \%$ of the thorium was recovered in the fertile streams. This reduced to $289 \%$ in Part III.

Overall uranium recovery was $93.26 \%$ in the fissile streams and $6.74 \%$ in the fertile streams. In Part III, over $99.4 \%$ of the uranium was recovered in the fissile streams. This reduced to $\sim 71 \%$ and $57 \%$ in Parts I and II, respectively.

The increase in the crossover of thorium in Part III and uranium in Parts $I$ and II is attributed to the tendency of entrainment of the minor component in the major component stream and to broken particles (see Tables 5-8 and 5-12).

The $1.15 \%$ crossover of thorium to the fissile stream and the $6.74 \%$ crossover of uranium to the fertile stream was a marked improvement over the $2.91 \%$ and $15.44 \%$ respective crossovers attained in the initial sequential operation.

\subsection{PARTICLE CRUSHING}

\subsubsection{Equipment Changes}

The fuel particle roll crusher was fitted with a more powerful drive system due to a periodic inability to start under load and to stoppages from overload. This was prevented in the initial sequential operation by restricting the flow of feed with an orifice.

Earlier operations indicated that crushed materials had, on occasion, entered the bearings. This presented the potential for accelerated wear and eventual seizure. To establish techniques for avoiding this, one bearing was fitted with a purge and another with sea1s. 


\subsubsection{Feed Material}

A portion of the classifier overhead fissile stream from Part III of the classification was used as feed to the fuel particle crusher. The fissile particles were conveyed from the TRISO bunker to the particle crusher feed bunker at a rate of $0.1 \mathrm{~kg} / \mathrm{s}$ and a conveying velocity of $15 \mathrm{~m} / \mathrm{s}$. The weight loss in the fissile bunker was $45.6 \mathrm{~kg}$; the weight gain in the feed bunker was $45.2 \mathrm{~kg}$. The weight lost by the feed bunker after the particles had been crushed was $46.4 \mathrm{~kg}$. These readings were all within $3 \%$. The feed weight was obtained from readouts from load cells on the feed bunker. These readouts were taken before and after crushing with all equipment turned off to reduce vibration. The size distribution and the burnable carbon, broken fuel particles, and heavy metal contents of the feed are given in Table 5-14.

\subsubsection{Crushing Operations}

Crushing rates were not obtainable from the rate of weight loss from the feed bunker because normal vibrations from the crushing caused large variations in the load cell readouts. Instead, the average crushing rate was obtained from the total weight crushed and the total run time. The crusher stopped at 44 min after startup, due to a tripped circuit breaker. The apparent average crushing rate to that time was $\sim 1.0 \mathrm{~kg} /$ min. The roll speed throughout the crushing run was $\sim 40 \mathrm{rpm}$.

It was assumed that crushing had been completed because the load cell readouts were constant, and tapping on the feed lines indicated that they were empty. Therefore, a restart was not attempted. However, during dismantling to investigate the cause of the stoppage, $\sim 0.3 \mathrm{~kg}$ of uncrushed feed was found.

The crusher gap was $546 \mu \mathrm{m}$ prior to startup and $597 \mu \mathrm{m}$ after the run. The crushed product characteristics are shown in Table 5-15. This sample was obtained by crushing $0.5 \mathrm{~kg}$ of the Part III overhead material 
TABLE 5-14

FUEL PARTICLE CRUSHER FEED CHARACTERISTICS FROM SEQUENTIAL OPERATION

$\begin{array}{lc}\text { Total weight } & 46.5 \mathrm{~kg} \\ \text { Burnable carbon } & 5.77 \% \\ \text { Thorium } & 3.43 \% \\ \text { Uranium } & 17.99 \% \\ \text { Broken BISO } & 80.88 \% \\ \text { Broken TRISO } & 10.97 \% \\ +850 \mu \mathrm{m} & 0.3 \% \\ -850+425 \mu \mathrm{m} & 93.6 \% \\ -425+355 \mu \mathrm{m} & 1.4 \% \\ -355+250 \mu \mathrm{m} & 1.7 \% \\ -250 \mu \mathrm{m} & 3.0 \%\end{array}$


TABLE 5-15

SEQUENTIAL OPERATION PARTICLE CRUSHER PRODUCT USED FOR SECONDARY BURNER FEED

\begin{tabular}{|c|c|c|}
\hline $\begin{array}{l}\text { Bulk density } \\
\text { Tapped density } \\
\text { Burnable carbon }\end{array}$ & & $\begin{array}{l}.28 \mathrm{~g} / \mathrm{cm}^{3} \\
.41 \mathrm{~g} / \mathrm{cm}^{3} \\
9.7 \%\end{array}$ \\
\hline $\begin{array}{c}\text { Mesh Size } \\
(\mu \mathrm{m})\end{array}$ & $\begin{array}{l}\text { Weight } \\
\text { Percent }\end{array}$ & $\begin{array}{c}\text { Cumulative } \\
\text { Weight } \\
\text { Percent }\end{array}$ \\
\hline+850 & 0.1 & 100.0 \\
\hline$-850+425$ & 48.6 & 99.9 \\
\hline$-425+355$ & 8.4 & 51.3 \\
\hline$-355+250$ & 13.9 & 42.9 \\
\hline$-250+125$ & 0.4 & 29.0 \\
\hline$-125+63$ & 22.3 & 28.6 \\
\hline$-63+45$ & 4.4 & 6.3 \\
\hline-45 & 1.9 & 1.9 \\
\hline
\end{tabular}


after an initial inspection of the crusher at the conclusion of the crushing and checking the final gap. Since all of the material was crushed at the final 597-um gap, it may be somewhat coarser and contain more unbroken fuel particles than the average material crushed for secondary burner feed.

\subsection{CRUSHED PARTICLE BURNING}

\subsubsection{Feed Material}

The feed material for the secondary burning portion of the sequential operations was the product from crushing a portion of the overheads (fissile stream) from Part III of the classification. The characteristics of the crushed feed are shown in Table 5-15. A gravity pneumatic feeder was used to add the material to the burner, and this was accomplished in about 4 min.

\subsubsection{Burning Operations}

No operating problems were encountered throughout the burning. Heat-up to ignition temperature took about $45 \mathrm{~min}$. Oxygen was introduced at that time and ramped up to $70 \%$ of the inlet gas concentration in about $10 \mathrm{~min}$. Total oxygen utilization, the main burn period, lasted $\sim 1 \mathrm{~h}$ $35 \mathrm{~min}$ at $280 \mathrm{l} / \mathrm{min}$ oxygen flow. The fluidizing gas velocity during this period was $0.8 \mathrm{~m} / \mathrm{s}$. After oxygen breakthrough in the off-gas, the oxygen was gradually reduced to $20 \%$ of the feed concentration to keep the oxygen concentration below $20 \%$ in the off-gas. After $\sim 50 \mathrm{~min}$, the fluidizing gas velocity was reduced over a period of $\sim 10 \mathrm{~min}$ to 0.45 $\mathrm{m} / \mathrm{s}$ for tail burning. The run was terminated after $\sim 20 \mathrm{~min}$ of tail burning. The total run time after ignition was $3 \mathrm{~h} 5 \mathrm{~min}$.

The midbed temperature, vessel, and filter differential pressures (DP), inlet gas flows, and off-gas concentrations are given in Figs. 5-15 through 5-18, respectively. 


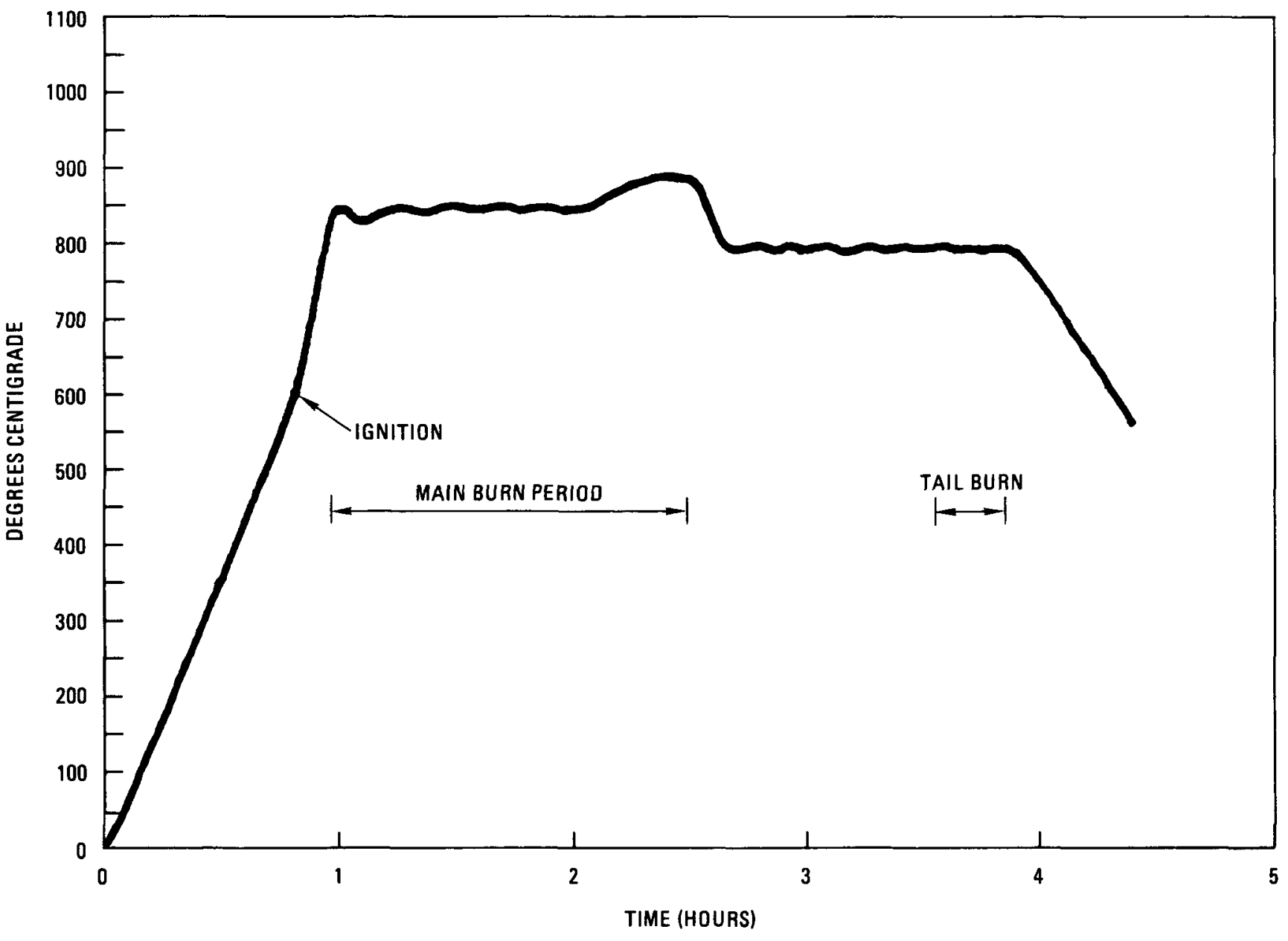

Fig. 5-15. Secondary burner mid-bed temperature 


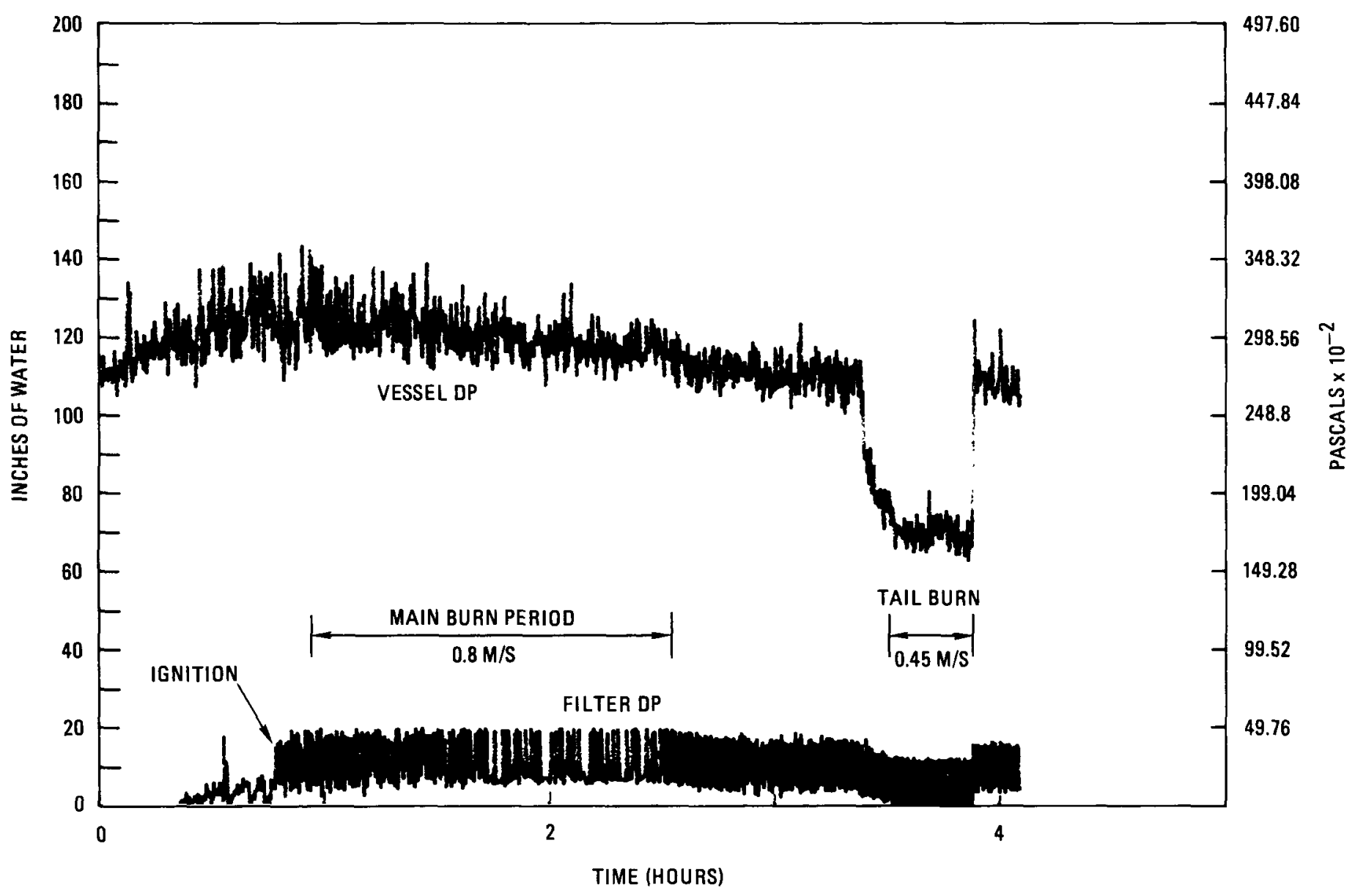

Fig. 5-16. Secondary burner pressures 


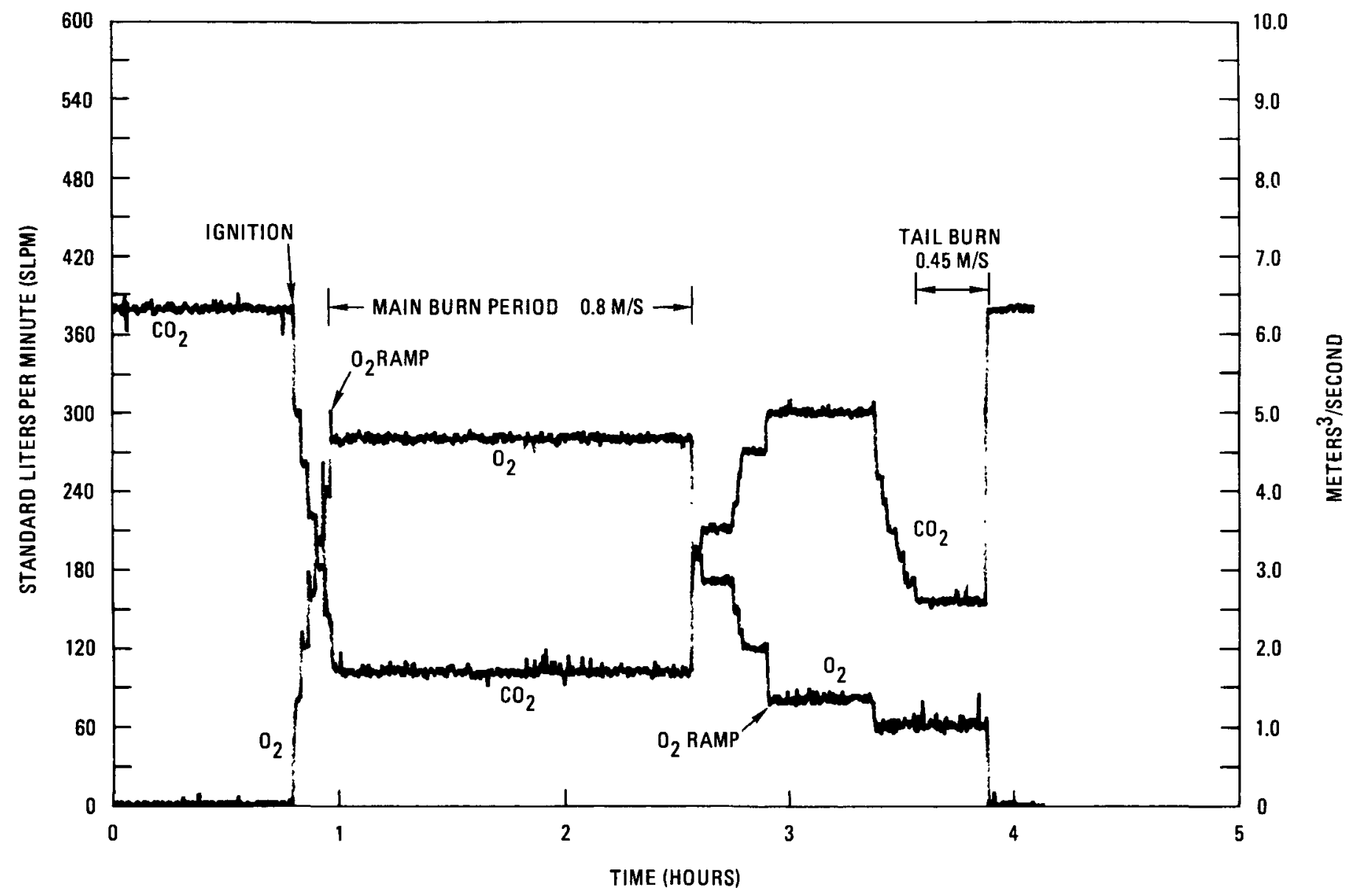

Fig. 5-17. Secondary burner gas flows 


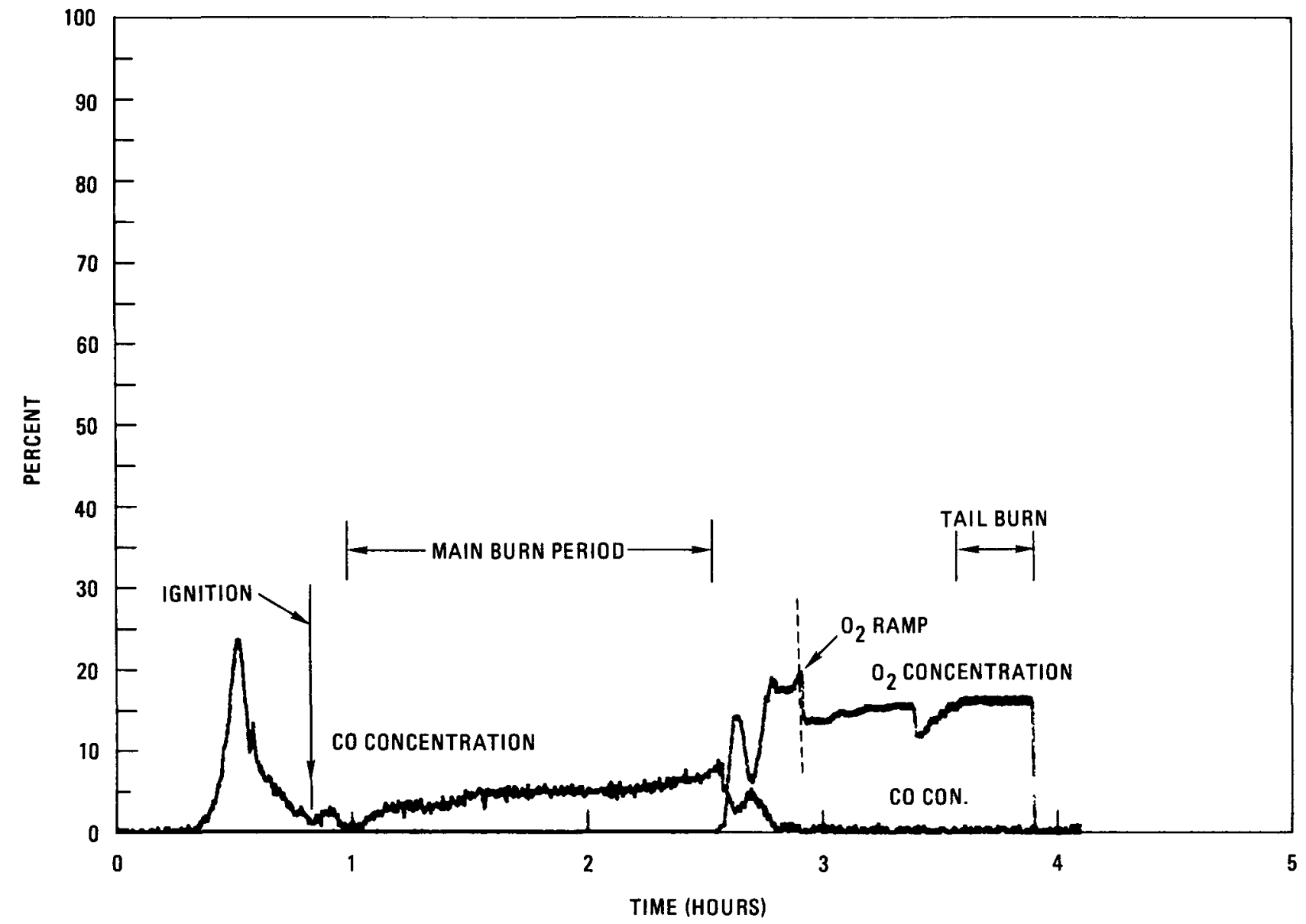

Fig. 5-18. Secondary burner off-gas concentration 


\subsubsection{Product}

An improved secondary burner product removal system was used to transport the product to the secondary burner product bunker. This system operated satisfactorily in a totally automatic mode. The weight gain in the product bunker was $31.2 \mathrm{~kg}$. The weight loss on removal was $31.0 \mathrm{~kg}$ and the actual weight was $31.3 \mathrm{~kg}$. The 1 oad cell readouts agreed with the actual weight within $1 \%$.

The product recovered contained only $0.30 \%$ burnable carbon. However, due to the widening of the crusher gap, $8.72 \%$ of the fissile fuel particles remained unbroken through secondary burning. The complete characteristics of this product are given in Table 5-16. 
TABLE $5-16$

SECONDARY BURNER SEQUENTIAL OPERATIONS PRODUCT CHARACTERISTICS

$\mathrm{kg}$

Burnable carbon

Uranium

Thorium

$\operatorname{SiC}(a)$

Total Product
0.09

6.07

0.81

24.33

31.30

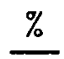

0.30

19.39

2.59

77.72

100,00

Note: $8.92 \%$ of fissile particles were unbroken. (a) By difference.

$\begin{array}{ccc}\begin{array}{c}\text { Mesh Size } \\ (\mu \mathrm{m})\end{array} & \begin{array}{l}\text { Weight } \\ \text { Percent }\end{array} & \begin{array}{c}\text { Cumulative } \\ \text { Weight } \\ \text { Percent }\end{array} \\ +850 & <0.1 & 100.0 \\ -850+425 & 10.4 & 99.9 \\ -415+355 & 0.8 & 89.5 \\ -355+250 & 10.6 & 88.7 \\ -250+125 & 43.0 & 78.1 \\ -125+63 & 17.4 & 35.1 \\ -63+45 & 8.4 & 17.7 \\ -45 & 9.3 & 9.3\end{array}$




\section{ANALYTICAL TECHNIQUES}

Each of the samples taken throughout the pilot plant sequential operations was analyzed for size distribution, carbon content, and broken fuel particles. The size distributions were determined by screen analysis. After screening, the mesh fractions were recombined and ignited in a muffle oven overnight at $900^{\circ} \mathrm{C}$ to obtain the weight loss from carbon combustion. The residues were screened into $+425-\mu \mathrm{m}$ and $-425-\mu \mathrm{m}$ fractions, and each fraction was leached for uranium and thorium content. The insoluble materials were crushed, reburned, and then leached again for uranium and thorium content.

Uranium present from broken TRISO particles is detected in the initial leaching. Comparison of this result with the total uranium from both leachings provides the estimate of the percent broken TRISO fuel particles. To obtain an estimate of the broken BISO fuel kernels, it was assumed that the thorium in the $+425-\mu \mathrm{m}$ fractions was from whole kernels and the thorium in the -425- $\mu \mathrm{m}$ fractions was from broken kernels. Since whole BISO kernels are generally larger than 425- $\mu \mathrm{m}$ and crossover is expected to be almost entirely from fragments less than $425-\mu \mathrm{m}$, the assumption is considered reasonable. 


\section{OVERALL MATERIAL BALANCE}

The overall thorium and uranium material balance for the sequential operation is shown schematically in Fig. 7-1. It included analysis and weights on 41 samples and 10 different products. These were required to provide the additional data needed to establish process results and product quality as well as a material balance. It is far more complex than the normal sampling and product streams resulting from processing 20 fuel elements. Since the number of samples and separate products removed greatly affect the accuracy of a material balance, the material unaccounted for was expected to be somewhat greater than under normal commercial plant conditions.

Figure 7-1 also shows the sample removal points, product streams, process steps, and bunker load cell readings as material was charged or removed as well as the material balance information.

The material balances for thorium and uranium were better than expected with $1.18 \%$ of the thorium and $2.12 \%$ of the uranium unaccounted for. A material balance through the classification steps only yielded an accountability of $98.28 \%$ of the thorium and $99.45 \%$ of the uranium, which were excellent results. 


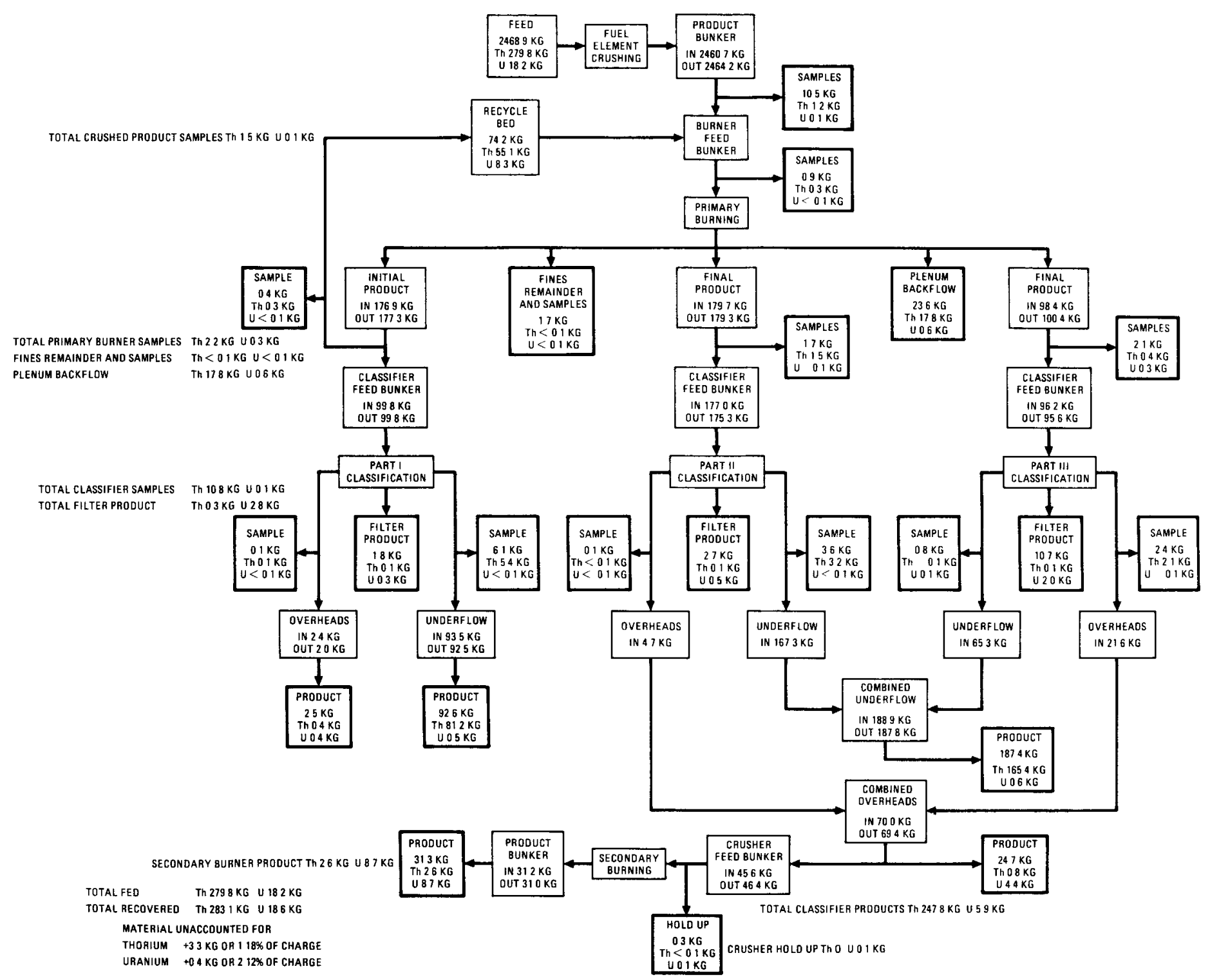

Fig. 7-1. Thorium and uranium material balance for cold pilot plant sequential operation 


\section{FUEL PARTICLE BREAKAGE SUMMARY}

The quantity of broken fuel particles has been shown to directly affect the crossover of fertile particles to the fissile stream and vice versa (Ref. 8-1). Therefore, this is an important parameter in the process streams and in the economics of fuel recovery through the classification process.

Fuel particle breakage through the various processes is shown in Table 8-1. The direct relationship to particle crossover is shown by Table 8-2. This relationship is somewhat diminished in crossover of fertile particles in Part II of classification and in crossover of fissile particles in Part III because these particles were the major components of the feed. The major components of the feeds tend to cross over in smaller quantities, while crossover of the minor component is increased in all of the classifications. However, the effect of particle breakage is evident in the quantity of broken particles that constituted the crossover. This was $82.1 \%$ for the fissile and $59.3 \%$ for the fertile. Therefore, the crossover due to whole particles was only $1.2 \%$ and $0.5 \%$ for the fissile and fertile, respectively.

\section{REFERENCE}

8-1. Strand, J. B., "Particle Classifier for HTGR Fuel Reprocessing Engineering Scale Unit Interim Development Report," DOE Report GA-A14930, General Atomic Company, July 1978. 
TABLE 8-1

FUEL PARTICLE BREAKAGE FOR PILOT PLANT SEQUENTIAL OPERATIONS

\begin{tabular}{|c|c|c|}
\hline & $\begin{array}{l}\text { Broken TRISO } \\
\quad(\text { wt } \%)\end{array}$ & $\begin{array}{l}\text { Broken BISO } \\
\quad(w t \%)\end{array}$ \\
\hline $\begin{array}{l}\text { Fuel element crushing and } \\
\text { transport to product bunker }\end{array}$ & $\begin{array}{c}8.7 \\
\text { (Range } 6.7-11.9 \text { ) }\end{array}$ & $\begin{array}{c}1.5 \\
\text { (Range } 0.9-2.5 \text { ) }\end{array}$ \\
\hline $\begin{array}{l}\text { Crushed fuel element burning } \\
\text { and transport to product } \\
\text { bunker }\end{array}$ & (Range $10.6-53.0$ ) & (Range $1.8-4.1$ ) \\
\hline $\begin{array}{l}\text { Through particle } \\
\text { classification }\end{array}$ & $\begin{array}{l}22.8 \\
\text { (Range } 18.7-48.9 \text { ) }\end{array}$ & $\begin{array}{l}3.2 \\
\text { (Range } 0.8-10.9)\end{array}$ \\
\hline
\end{tabular}


TABLE 8-2

BROKEN FUEL PARTICLES IN CLASSIFIED PRODUCTS

\begin{tabular}{|c|c|c|c|c|}
\hline & $\begin{array}{c}\text { Broken } \\
\text { Particles } \\
\text { (wt \%) }\end{array}$ & $\begin{array}{c}\text { Crossover } \\
(\%)\end{array}$ & $\begin{array}{c}\text { Broken } \\
\text { Particles } \\
(w t \%)\end{array}$ & $\begin{array}{c}\text { Crossover } \\
(\%)\end{array}$ \\
\hline Part I & 48.9 & 43.0 & 0.8 & 0.5 \\
\hline Part II & 37.1 & 29.2 & 3.5 & 0.1 \\
\hline Part III & 18.7 & 0.6 & 10.9 & 11.0 \\
\hline Overall & 22.8 & 6.7 & 3.2 & 1.2 \\
\hline
\end{tabular}

CROSSOVER DETAILS

\begin{tabular}{|c|c|c|c|c|}
\hline \multirow{2}{*}{$\begin{array}{c}\text { Crossover } \\
\text { Total } \\
(\%)\end{array}$} & \multirow{2}{*}{$\begin{array}{c}\text { Broken } \\
\text { Particles } \\
(\%)\end{array}$} & \multirow{2}{*}{$\begin{array}{c}\text { Whole } \\
\text { Particles } \\
(\%)\end{array}$} & \multicolumn{2}{|c|}{ Crossover (\%) } \\
\hline & & & $\frac{\text { Due }}{\text { Broken }}$ & Whole \\
\hline 6.7 & 82.1 & 17.9 & 5.5 & 1.2 \\
\hline 1.2 & 59.3 & 40.7 & 0.7 & 0.5 \\
\hline
\end{tabular}




\section{COMPARISON OF INITIAL AND SECOND SEQUENTIAL OPERATIONS}

No serious operating problems were encountered with the fuel element size-reduction system in either sequential operation. The overheating of the bearings on the secondary crusher in the initial sequential operation was avoided in the second sequential operation by the installation of prelubrication systems. Crushing times and product size distributions were similar in both operations and met throughput and burner feed requirements. The addition of the rotary valve feeder allowed a lower conveying velocity to be used; however, particle breakage was not reduced.

Operating problems in the crushed fuel element burning system were essentially eliminated by the modifications made to the system. The second sequential operation was continued to completion, resulting in a product well within the requirements for secondary burning and dissolution. Plenum backflow was reduced to $19 \%$ of that in the initial operation, and the fines heel was reduced to $0.5 \mathrm{~kg}$. Peak carbon burn rates exceeded the design rates in the second operation, and all operating, throughput, and product specifications were met.

Particle classification was achieved at design throughput rates in both sequential operations. The crossover was substantially reduced in the second operation and resulted in a $98.9 \%$ and $93.3 \%$ recovery of thorium and uranium in their respective streams versus a $97.1 \%$ thorium and $84.5 \%$ uranium recovery in the initial operation. This is an even more marked improvement because essentially all of the primary burner product was classified in the second operation while the fines and coarse fractions were removed from the fuel bed of the initial operation. 
The fuel particle crusher provided the only operating and process problem in the second operation. It had provided relatively trouble-free operation in the initial sequential run.

Crushed fuel particle burning presented no operating problems in either sequential operation. However, the product from the second contained $8.7 \%$ unbroken particles versus $0.5 \%$ in the initial operation. This was attributable to the excessive gap on the crusher and not to secondary burning problems.

Operating experiences during the initial sequential operation enabled the selection of the proper feed and flow rates for trouble-free operation of the pneumatic transport systems in the second sequential operation. 


\section{CONCLUSIONS}

The demonstration of the cold head-end pilot plant processes for HTGR fuel reprocessing has been successful within the range of testing completed to date. Processes, throughput, product specifications, and equipment operation were generally adequate or exceeded the requirements for a commercial facility. The minor problem areas should be easily overcome. Further efforts are required to demonstrate longer-term equipment reliability, automate process controls, demonstrate remote maintenance and operation concepts, continue to minimize particle breakage, improve sampling techniques and material accountability, and demonstrate the processes with advanced fuel types.

The fuel element crushing system exceeded the throughput requirements for a commercial facility design. The product easily provided the fluidization qualities needed for efficient combustion in the primary burner. Further reduction in fuel particle breakage is desirable to improve the economics of fuel recovery.

Gravity fines recycle on the primary burner resulted in trouble-free operation and minimization of unburned carbon. The product exceeded the requirements for effective combustion of the crushed TRISO fuel particles in the secondary burner and dissolution of the BISO fuel particles after separation.

Air classification as a means to separate fissile and fertile fuel particles provides the throughput and separability needed in a commercial facility and is more efficient than sieve separation techniques. Its only limitation thus far discovered is in the separation of broken particles, which also cannot be accomplished by sieving. 
The fuel particle crusher exceeds the throughput requirements, but because of the precision construction and assembly requirements necessary to ensure the proper gap, an improved design is desirable.

The secondary or crushed particle burning process, like the primary burning process, is relatively problem-free and requires no process changes. Automation of control and development of remote operation and maintenance techniques should provide the most benefits to a commercial facility design regarding these systems.

Pneumatic solids transport has provided reliable means for all material movement while minimizing the risk of release of radioactive materials by a negative pressure system. In line sampling, improvements and minimization of fuel particle breakage should be effected to optimize these systems. 
11. FUTURE WORK

11. 1. GENERAL

Process and equipment development of the HTGR fuel reprocessing dry head-end pilot plant will concentrate on the solution of remaining technical issues on the individual unit operations, with the eventual objective of upgrading to a pilot plant which is fully prototypical to a commercial plant. The prototypical plant will have the basic advantage attendant with demonstration of full-scale, remotely operable and maintainable equipment and processes that will avoid extremely costly errors with their hot cell counterparts. Less costly operator and engineer training and familiarization can also be achieved on the prototypical equipment, along with the ability to study in depth any unforeseen process upsets that may occur in the commercial facility. Improvements in designs and new technology developments can also be tested prior to a commitment to the commercial facility.

Ongoing development activities that are applicable to all of the unit operations include design and testing of remotely operable and maintainable equipment, design and testing of the required special remote-maintenance tools and fixtures, automation of controls, and testing of equipment for wear rates, failure rates, and reliability. Advanced fuel designs will also have an impact on the current equipment and processes. Modifications that compensate for alterations in the fuel will have to be developed and tested.

\subsection{FUEL ELEMENT SIZE-REDUCTION SYSTEM}

The earlier design evaluation of the fuel element size-reduction system revealed several areas in the design for which changes were required or desirable (Ref. 11-1). These fell into three general 
categories: (1) designs requiring modification for hot cell use, (2) designs requiring completion for hot cell use, and (3) designs requiring further evaluation. The designs that required modification for hot cell use were basically acceptable but needed minor changes to be compatible with remote operation or more severe commercial use. They did not require changes that affected their basic function. Designs that required completion for hot cell use were those that were omitted initially due to programmatic constraints or that presented potential problems in a hot cell but could be tested with low-level radioactive materials. Designs that required evaluation were those that presented departures from the initial designs or design philosophy and were not obvious needs or viable tradeoffs without further study.

The ventilation enclosure and the crushing wear surfaces both require minor changes for commercial hot cell use. Although the current design of the ventilation enclosure is quite adequate, it utilizes standard methods and fasteners for the removable panels. These will need modification to be compatible with remote operation and removal.

The wear surfaces of both the primary and secondary crushers were fabricated of mild steel because of cost considerations, fabricability, and the potential to provide wear data. For the more severe use of a commercial facility, it will be necessary to merely replace the mild steel with hardened materials to improve wear life.

The designs that require completion for hot cell use include a through-the-cell-wall drive system, the capability for start under load, a fuel loading port, lubrication systems, and interchangeable pitman parts.

It was recognized at the onset that a sophisticated drive system is required for the final Uniframe design. The present system was used because of budgetary and scheduling considerations, and it has been found to be adequate for the cold pilot plant tests. However, radiation 
effects on motors, V-belts, and lubricants, as well as remote maintenance requirements, make it desirable to design and test a through-the-cell-wall drive system prior to commission to hot cell use.

Start-under-1oad capabilities were not specifically addressed for the present drive system because it was recognized that the more sophisticated through-the-cell-wall system would present different conditions. During the tests to date, all equipment except the primary crusher readily started under load. It appears that only the primary crusher will require a special start-under-load design.

The method for charging fuel elements in the cold pilot plant was compatible with available cranes, fuel lift fixtures, ventilation capabilities, single element charging, and low-level radiation containment practices. For the commercial facility, the fuel charging system will be required to provide for several elements, automatic conveying, air lock charging, broken fuel elements, and remote repair.

The present lubrication systems include standard oil and grease lubrication and contain components that can suffer damage from radiation. More reliable and maintainable lubrication techniques are required for a commercial facility.

The present designs of the primary and secondary crusher pitman assemblies contain many components that are interchangeable between crushers. However, the configurations and machining render them quite different. For the final design, efforts to design assemblies that are interchangeable except for removable crushing surfaces will be undertaken to reduce the maintenance and replacement parts requirements.

On a few occasions during the initial testing of the secondary crusher, materials failed to crush completely. Since that time, only a single failure has occurred. Even at the low frequency of occurrence, it will be necessary to provide a means for clearing the secondary crusher to avoid the need to dismantle equipment to remove the blockage. 
The tests on the oversize crusher revealed that it did not reduce $100 \%$ of the oversize material to $<4780 \mu \mathrm{m}$ as required by the design criteria. This was attributed to the spring loading of the wear plates, which did not provide a fixed gap. This problem and the potential difficulty in setting the gaps remotely, plus material holdup in the crusher cavities, make it necessary to upgrade the design or investigate alternatives.

Designs that were identified as requiring evaluation included (1) a primary crusher clearing device, (2) the variable primary crusher nip angle, (3) the removable stationary jaws on the primary and secondary crushers, (4) the fixed close-side settings on the primary and secondary crushers, and (5) the oversize screening-crushing system.

Because of the remote possibility that material could hold up within the primary crusher as it has done on rare occasions in the secondary crusher, it becomes desirable to investigate the addition of a primary crusher clearing device. The decision on this design would be based on the achievable nip angle in the final design, the simplicity of the device, its fallure modes, start-under-load-capabilities, and the incidence of holdup in remaining tests.

Presently the design of the primary crusher includes the ability to vary the nip angle. This was included because the exact angle required for crushing fuel elements had not been established at the onset of design. Since then, testing has established the largest nip angle at which the probability of crushing is high. However, since the variable angle design is complex and the probability for crushing increases at smaller nip angles, the design of a crusher with the smallest fixed nip angle practicable will be investigated.

Both jaw crushers have removable and reversible stationary jaws and are therefore complex. This feature was provided to compensate for potential wear on the jaw surfaces. Crusher designs with fixed stationary jaws would be less complex and require less complex remote maintenance 
tooling. Therefore, the fixed-jaw concept will be investigated along with continued monitoring of wear rates and study of failure effects.

The close-side settings of the jaw crushers determine the size of material that must pass the next stage. These settings are fixed in the design and can only be changed by installing toggles of a different length. Because of the potential need for minor adjustments due to tolerance stack-up in the constructed assembly and to wear, a variable close-side setting will be added to the design.

The oversize screening-crushing system was included to ensure a crushed product suitable for combustion in a fluid-bed burner and to detect problems in the preceding crushing stages. Testing has indicated that the primary burner can process crushed product directly from the tertiary crusher. The general complexity of the oversize screeningcrushing system and the need for special remote fixtures for its removal make it desirable to investigate the consequences of omitting the system. Tests will be conducted on burning product produced without the system. If no problems occur, a design without the system will be established.

\subsection{CRUSHED FUEL ELEMENT BURNER}

The earlier design evaluation of the crushed fuel element burner led to the recommendation for development of two design concepts for a prototype primary burning system (Ref. 11-2). One uses existing heatingcooling design but simplifies remote maintenance and burner operation. The other requires a modified heating-cooling design as well as simplification of remote maintenance and burner operation.

The present heating-cooling system uses an external cooling shroud and susceptor, a top insulation bonnet assembly, and sliding seals between the shroud and burner tube. A burner design with internal heating and cooling would eliminate these components and simplify remote maintenance. The feasibility of heating the burner with hot gas and 
cooling with an internal heat exchanger will be evaluated and tested on a smaller scale if the evaluation is promising.

The present cooling shroud consists of an upper and a lower section, each of which is hinged to allow remote removal of the burner. This design is complex and there are many surfaces that require sealing. Remote removal of the burner, even with the present shroud design, is complex and requires precision locating for reinstallation. Therefore, a single-section shroud that is attached directly to the burner and is removed with the burner will be designed to eliminate the sealing problems, omit opening devices, and simplify burner removal and replacement.

The top of the burner presently requires a remotely operable flange for attaching the vessel to the top cap. There are no practical reasons fequiring removal of the top cap since there are no in-vessel filters as with the secondary burner. In addition, the flange presents a potential for leakage and failures due to heat cycling. Therefore, the flange will be eliminated from future designs.

Thermocouples are commonly attached to the exterior surfaces of the burner by drilling and peening or by welding. These methods are sometimes unreliable and damaging to the thermocouples. A design for holding the thermocouples in place by spring-loaded clips will be tested for reliability and effect on the accuracy of temperature readings. This will also provide an easier method for remote replacement of the thermocouples.

The gas distributor and plenum section are removable via a flanged connection and remotely operable clamp at the bottom of both the primary and secondary burners. This connection provides the potential for leakage and warping due to its position in the hot zone of the vessel assembly. A newly designed gas distributor section that locates this flange in a cooler zone has been constructed and installed for testing on a $0.1-\mathrm{m}$ secondary burner system. 
Metering of the recycled fines into the burner is accomplished using a rotary valve. This valve is subject to low pressure, high temperature, and fairly severe wear conditions. An improved valve is being designed to overcome these potential problems. The new design will be extensively tested in a $0.2-\mathrm{m}$ primary burning system.

The primary burning operation has evolved from an almost totally operator-controlled process to a semiautomatically controlled process. A fully automatic system is being installed for future testing. This system will control oxygen ramping, cooling, heating, fresh feed rate, and midreactor oxygen flow for fines burning during startup, steady state, and shutdown of the process. The data acquisition by a computer used during the second sequential operation will be expanded to control the process for achieving a chosen burn rate.

\subsection{FUEL PARTICLE CLASSIFICATION}

The earlier design evaluation of the fuel particle classifier led to the following conclusions (Ref. 11-3). The separation of the cyclone and the filter chamber in the particle classification system results in the separate collection of product in the filter vessel and product in the overhead bunker. The present cyclone is inefficient and results in some whole fissile particles in the filter chamber. Since the material in the filter chamber cannot be disposed of and therefore requires processing, a combined cyclone-filter chamber or elimination of the cyclone with direct filter discharge into the overhead bunker will be investigated for use in the system.

Broken fuel particles cannot be separated either by pneumatic classification or sieving. There is a minimum achievable breakage during processing, which may or may not increase in advanced fuel designs. Since these particles constitute the majority of crossover, alternate methods of separating fuel particles are worthy of investigation. In the future, electrostatic and shape separation techniques will be tested for incorporation as a part of the classification system. 
The design of advanced fuel types will affect the efficiency of classification proportionally to the differences in diameter and density between the fissile and fertile fuel particles. Studies are currently under way to establish the parameters for separability so that the advanced designs will be able to take separability into account.

A middle enrichment uranium (MEU) fuel has been proposed as a solution to the potential proliferation of nuclear capabilities. The separation of the fissile and fertile fuel particles is the key step in reprocessing of these fuels. Since the particles are more similar in diameter and density than previous fuels, classification studies using these particles are planned.

\subsection{FUEL PARTICLE CRUSHER}

The earlier design evaluation of the fuel particle crusher resulted in an improved design (Ref. 11-4). The present design of the crusher requires very close manufacturing tolerances, high-level QA follow-up, and precision assembly. The new design that has been completed simplifies manufacturing and bearing preloading during assembly, includes redundant bearing seals and temperature compensating bearings, and reduces the overall housing size. Since the present crusher exhibited the only operating problem of any consequence during the second sequential operation, the construction, installation, and extensive testing of the new design will be an important part of the pilot plant development.

\subsection{CRUSHED FUEL PARTICLE BURNER}

Presently the primary burner is required to reduce the burnable carbon to a very low level to reduce risks to the secondary burner. This requires considerable process time for tail burning to reduce the quantity of fines and necessitates reburning if an upset occurs. A series of tests are planned using fuels with successively higher quantities of unburned graphite to verify a feed specification that presents an acceptable risk in secondary burning. 
As a result of the design evaluation of the secondary burner (Ref. 11-5), an improved filter chamber has been designed which eliminates the side charging port on the secondary burner and simplifies the thermowell and filter removal. In the future, this design will be tested on a $0.1-\mathrm{m}$ secondary burning system.

\subsection{SOLIDS HANDLING SYSTEMS}

The design evaluation of the solids handling systems resulted in the planning of test programs and design changes (Ref. 11-3). Extensive testing of wear and failure rates for components of the solids handling system is planned to supplement the limited use these components receive in normal pilot plant operations. Several acceptable couplers have been used on the piping of the solids handling systems. However, efforts are continuing to investigate a number of other couplers which may be more amenable to remote operations. The development of reliable solids flow rate and level sensors and methods for locating and removing blockages in transport lines is under way. Methods and devices for improved feed to transport lines, more accurate load cell readouts, and precise sampling are also under investigation.

\subsection{CONCLUSIONS}

The design evaluations and test programs associated with each of the systems in the HTGR fuel reprocessing cold-dry head-end pilot plant have led the way toward future improvements. In addition, a preliminary maintainability analysis (Ref. 11-6) has shown the areas where failures will result in the longest downtimes. These are areas where design efforts on equipment maintainability will benefit most. A combination of knowledge from past efforts and future testing will eventually result in a fully prototypical plant and greatly reduce the risks involved in the initial commercial facility. 
REFERENCES

11-1. Strand, J. B., "Design Evaluation of the HTGR Fuel Element Size Reduction System," DOE Report GA-A14859, General Atomic Company, June 1978 .

11-2. Rode, J. S., "A Design Evaluation of the 40-cm (16-inch) Primary Burner System," DOE Report GA-A14452, General Atomic Company, June 1977.

11-3. McNair, J. M., "Design Evaluation, Solids Handling and Air Classifier," DOE Report GA-A14860, General Atomic Company, to be published.

11-4. Johansen, N. W., "HTGR Fuel Particle Crusher Design Evaluation," DOE Report GA-A14957, General Atomic Company, October 1978.

11-5. Rode, J. S., "A Design Evaluation of the 20-cm (8-inch) Secondary Burner System," DOE Report GA-A14510, General Atomic Company, August 1977.

11-6. Rode, J. S., and J. B. Strand, "A Preliminary Maintainability Analysis of the HTGR Dry Head-End Reprocessing System," DOE Report GA-A14678, General Atomic Company, November 1977. 


\section{ACKNOWLEDGMENTS}

The authors are greatly indebted to the following technicians whose timely suggestions, skills, and diligent efforts have contributed a great deal to the development of the pilot plant to its present status: G. M. Cox, R. M. Earle, P. L. Kno11, J. W. McLean, E. Simmons, R. W. Wheatly, M. B. Zacavich, and their supervisor, T. D. Wright. 